The Catholic University of America, Columbus School of Law

CUA Law Scholarship Repository

\title{
Discerning the Environmental Perspective of Pope Benedict XVI
}

Lucia A. Silecchia

The Catholic University of America, Columbus School of Law

Follow this and additional works at: https://scholarship.law.edu/scholar

Part of the Environmental Law Commons, and the Religion Law Commons

\section{Recommended Citation}

Lucia A. Silecchia, Discerning the Environmental Perspective of Pope Benedict XVI, 4 J. CATH. SOC. THOUGHT 227 (2007). 


\title{
Discerning the Environmental Perspective of Pope Benedict XVI
}

\author{
Lucia A. Silecchia
}

\begin{abstract}
Two movements are interacting here. One is that of human beings who do not exploit the world and do not want to detach it from the Creator's governance and make it their own property; rather they recognize it as God's gift and build it up in keeping with what it was created for. Conversely, we see that the world, which was created to be at one with its Lord, is not a threat but a gift and a sign of the saving and unifying goodness of God. ${ }^{1}$
\end{abstract}

\section{Introduction}

As commentators begin to assess the legacy left behind by Pope John Paul II, they surely will note with interest the contributions that he made to the advancement of Catholic social teaching regarding the necessity for careful stewardship of creation, and the inextricable link that exists between ecological concerns and genuine human development. ${ }^{2}$ The papacy of Pope John Paul II was marked by landmark events in environmental thought including, perhaps most notably, his 1990 Message for the World Day of Peace, his promulgation-with Ecu-

Lucia A. Silecchia is Professor of Law at The Catholic University of America, Columbus School of Law. All of Pope Benedict XVI's papal statements cited in this paper are available on the website of the Holy See, www.vatican.va and are also on file with the author.

1 Joseph Cardinal Ratzinger, "In The Beginning" . . A Catholic Understanding of the Story of Creation and the Fall 64-65 (Boniface Ramsey, O.P. trans.) (1986) (hereinafter "In THE BEGINNING").

${ }^{2}$ In an earlier paper, I have discussed the response of Pope John Paul II to ecological concerns, and the many contributions that he made to the development of modern Catholic social teaching in this area. See generally Lucia A. Silecchia, Environmental Ethics from the Perspectives of NEPA and Catholic Social Teaching: Ecological Guidance for the $21^{\text {st }}$ Century, 28 WILLIAM \& MARY ENVTI. L. \& POL'Y Rev. 659, 690-723 (2004). Much of the discussion in Section II, below, is derived from this work. For additional reflections on Pope John Paul II's contribution to this area and, more generally, on Catholic teaching on ecological matters, see also ChARLES M. MURPHY, AT Home on Earth: Foundations for a Catholic Ethic of the Environment 106-27 (1989); Marjorie Keenan, From Stockholm to Johannesburg: An Historical Overview of the Concern of the Holy See For the Environment 1972-2002 (2002); John HaRt, Care for Creation: Catholic Social Teaching on the Environment, 9 Josephinum J. Of Theology 120 (2002); Maura A. Ryan \& Todd David Whitmore, eds. The Challenge of global Stewardship: Roman CaTholic Responses (1997); Robert W. Lannon, Catholic Tradition and the New Catholic Theology and Social Teaching on the Environment, 39 CATH. LAW.

JOURNAL OF CATHOLIC SOCIAL THOUGHT - 4:2, 2007, 227-269. 
menical Patriarch Bartholomew I-of the Common Declaration on Environmental Ethics in 2002, and the forceful intervention of the Vatican in international conferences and conventions concerning the environment and international development. Although environmental problems clearly existed before the papacy of Pope John Paul II, the years of his papacy (1978-2005) were closely aligned with the years during which many national governments and secular international entities concerned themselves with ecological matters to a far greater extent than ever before. This greater attention-coupled with more urgent appreciation for and evidence of ecological harms-prompted the unprecedented intervention of the Holy See in environmental matters during the papacy of Pope John Paul II.

Now, his successor, Pope Benedict XVI, faces a world in which ecological concerns persist, and pressures for solutions continue to come from various constituencies. In particular, the recent public attention paid to fears about global climate change continue to raise the profile of ecological matters. ${ }^{3}$ Thus far, however, little attention has been paid to how Pope Benedict XVI may approach these issues or how his thought on ecological questions has developed through his writings during his many years as a leading theologian.

This paper will explore the writings of Pope Benedict XVI to ascertain the way in which he might approach the environmental questions of the modern world. Although, to date, he has reflected upon such issues primarily as a theologian and not as a pragmatic policy maker, the theological writings of Pope Benedict XVI provide insight into the approach he may take as international ecological issues confront his papacy.

When it comes to environmental issues, Pope Benedict XVI will not write on a blank slate. His theological and scholarly writings to date reflect an intricate, thoughtful reflection on the created world and the responsibility of humanity to that world. Indeed, in the internationally televised homily at the very inauguration of his papacy, when he was

353 (2000); Daniel M. Cowdin, John Paul II and Environmental Concern: Problems and Possibilities, 28 Living Light 44 (1991-92); and Jeff Severns Guntzel, John Paul II's Ecological Legacy, National Catholic RePoRter, June 17, 2005 at 9A. For an excellent compilation of essays discussing Catholic social thought and ecology from various perspectives, see generally Drew ChristTANSEn, S.J. \& Walter Grazer, Eds. "AND God Saw That It Was Good": Catholic Theology and the Environment (1996).

${ }^{3}$ As this paper was going to press in late March 2007, the Pontifical Council for Justice and Peace was planning to convene an international Study Summit on Global Climate Change and Development, to be held at the Vatican on April 26-27, 2007. See CNS News Brief, Pontifical Council Plans Spring Seminar on Climate Change, January 30, 2007 (http://catholicnews.com/data/briefs/cns/20070130.htm). 
invested with the pallium, he bluntly lamented to a worldwide audience that "the earth's treasures no longer serve to build God's garden for all to live in, but they have been made to serve the powers of exploitation and destruction." ${ }^{4}$ This statement surprised some commentators, ${ }^{5}$ but it placed ecological concerns "on the map," so to speak, in Pope Benedict XVI's young papacy.

This paper will begin by providing some historical context for Pope Benedict XVI's work in this area. It will then discuss four principal themes expressed repeatedly in his past writings that are likely to provide the basic framework for his approach to the ecological difficulties that exist at the dawn of the twenty-first century. It will then conclude with some predictions as to the ecological issues Pope Benedict will face in the years ahead, with attention to some of his early papal statements on ecological matters.

\section{Context}

In a recent reflection on Pope John Paul II's environmental legacy, a commentator noted, "[h]ow future popes will respond to the crisis Pope John Paul II attempted to illuminate throughout his reign is unclear.

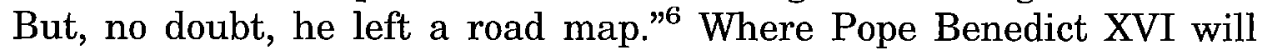
travel on that map remains to be seen. However, he comes to the papacy with a far more fully developed environmental legacy than that inherited by most of his predecessors. ${ }^{7}$ Although this paper will focus primarily on the thought of Pope Benedict XVI, a brief understanding of the current context-with "snapshots" of a few highlights from Pope John Paul II's papacy—can be useful.

Under Pope John Paul II, the Vatican became a far more active participant in international discussions of ecological issues and human development problems. He "persistently tied a stewardship message to

\footnotetext{
${ }^{4}$ Pope Benedict XVI, Homily of His Holiness Benedict XVI at Mass for the Imposition of the Pallium and Conferral of the Fisherman's Ring for the Beginning of the Petrine Ministry of the Bishop of Rome, Rome (April 24, 2005) [hereinafter "Inaugural Homily"].

${ }^{5}$ This declaration immediately attracted the attention of observers. See, e.g., David Quinn \& Richard Owenin Rome, The Human Race Is the Sheep Lost in the Desert . . . IRISH INDEPENDENT, April 25, 2005 (discussing Pope Benedict XVI's Inaugural Homily, and noting "the new Pope prov[ed] surprisingly outspoken - critical of the destruction of the environment."); and $I d$. ("He decried the environmental destruction of much of the earth and the exploitation of the world's resources.").

${ }^{6}$ Guntzel, supra note 2, at 10A.

${ }^{7}$ But see Id. (arguing that, in contrast to his more publicized teachings, "John Paul II's less-known legacy of strongly-worded statements denouncing the destructive relationship of humans to their habitat and promoting the spiritual necessity of environmental stewardship were little noticed . . . in his lifetime.").
} 
his more widely covered concerns over the excessive behavior of industrial nations, the adventures of science, and the plight of the world's

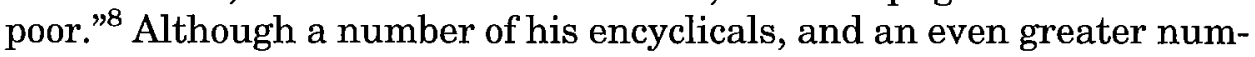
ber of his public addresses and comments made reference to the environment, four very specific events during the papacy of Pope John Paul II bear mentioning, as they provide an important context for the ecological position in which Pope Benedict XVI's papacy begins.

First, in his 1988 encyclical Sollicitudo Rei Socialis ("On Social Concern") ${ }^{9}$ Pope John Paul II became the first Pope to provide a substantial discussion of ecological concerns in an encyclical. He articulated a number of themes that he would reiterate throughout his papacy, including the connection between ecology and human development, the link between environmental protection and personal morality, and the dangers of over-consumption in a world of limited resources. ${ }^{10}$ Sollicitudo Rei Socialis proposed a comprehensive moral framework through which ecological issues should be viewed. More importantly, it proposed this framework in the formal context of an encyclical, thus affording it greater weight and broad attention.

Second, Pope John Paul II's 1990 World Day of Peace statement, Peace With All of Creation, ${ }^{11}$ marked the first time that a pope issued a formal document devoted solely to ecological matters. ${ }^{12}$ Although not an encyclical, this widely publicized document presented a comprehensive view of Pope John Paul II's ecological vision and, in doing so, greatly increased the profile of the Holy See in environmental affairs. It articulated such traditional themes such as the moral component of ecological problems, the importance of respecting the dignity of the human person in ecological discussions, the identification of the right to a safe environment as a basic human right, the link between ecology, poverty, and human development, and the environmental impact of nuclear and conventional warfare. ${ }^{13}$ This urgent call to international action highlighted the traditional aspects of Catholic social teaching

\footnotetext{
${ }^{8}$ Guntzel, supra note 2, at 9A.

${ }^{9}$ Pope John Paul II, Sollicitudo Rei Socialis (December 30, 1987), in CATHOLIC Social Thought: The Documentary Heritage 395 (David J. O'Brien \& Thomas A. Shannon eds., 1992) [hereinafter "CATHOLIC SOCIAL THOUGHT"].

${ }^{10}$ For further discussion, see generally Silecchia, supra note 2, at 693-697.

${ }^{11}$ Pope John Paul II, Message for the Celebration of the World Day of Peace (January 1, 1990), available at www.churchdocs.org/papal/jp.ii/ecology.crisis.

${ }^{12}$ See Guntzel, supra note 2, at 9A (reporting that this statement "marked what would be the beginning of a redoubling in his commitment to what he would come to call an 'ecological conversion'").

${ }^{13}$ See Silecchia, supra note 2 , at 697-704.
} 
more directly and to much more public notice than prior documents. Many of these themes were rearticulated in the landmark 1994 edition of the Catechism of the Catholic Church ${ }^{14}$ written with the close collaboration of then-Cardinal Ratzinger. The Catechism devoted a significant amount of attention to environmental matters-largely a first for catechetical documents. ${ }^{15}$

However, it was not only through papal teaching documents where Pope John Paul II asserted the Church's ecological vision. In two international events-one diplomatic and one ecumenical-he brought Catholic social teaching to bear on ecological concerns. The first of these events was the high profile and outspoken participation of the Holy See in the United Nations Conference on Environment and Development in June, 1992. ${ }^{16}$ Better known as the "Rio Conference," at this gathering,

experts and diplomats gathered to set goals and policies that would, in theory, guide the world community in its response to environmental matters. On the one hand, it could be said that the Holy See developed no new doctrine in connection with the Rio Conference. However, the Rio Conference afforded the Holy See the opportunity to bring its developing environmental teachings to the word stage. ${ }^{17}$

In particular, the Holy See stressed that "[t]he basic principles that should guide ... considerations of environmental issues are the integrity of all creation and respect for life and the dignity of the human person"18 and that "inhabitants of wealthier, developed nations ha[ve] a moral obligation to meet their environmental stewardship responsibilities in a way that would create long-term environmental benefit to the poorer corners of the globe."19 These themes, strongly reiterated in the 2002 United Nations World Summit for Sustainable Development marking the tenth anniversary of the Rio Conference, placed the Holy See at odds with many other participants at the Rio Conference. ${ }^{20}$ With

\footnotetext{
${ }^{14}$ United States Catholic Conference, Catechism of the Catholic Church (English ed. 1994). The CATECHISM begins its discussion of ecological responsibility by noting:

[use] of the mineral, vegetable and animal resources of the universe cannot be divorced from respect for moral imperatives. Man's dominion over inanimate and other living beings granted by the creator is not absolute; it is limited by concern for the quality of life of his neighbor, including enerations to come; it requires a religious respect for the integrity of creation. $I d$. at $580, \mathbb{2} 2415$.

${ }^{15}$ See Silecchia, supra note 2 , at 721-723.

${ }^{16}$ Id. at $713-20$.

${ }^{17} I d$. at 713-14.

${ }^{18}$ Memorandum on the Holy See's Position, in Serving the Human Family: The Holy See At The Major United Nations Conferences 111 (Carl J. Marucci, ed., 1997).

${ }^{19}$ Silecchia, supra note 2, at 717-18.

${ }^{20}$ See discussion of the Holy See's intervention at the Rio Conference in Silecchia, supra note 2 , at 713-723.
} 
that, the Holy See established a significant role for itself in discussions on ecological matters.

Finally, in 2002, Pope John Paul II signed the Common Declaration On Environmental Ethics (popularly known as the "Venice Declaration") with the Ecumenical Patriarch of the Greek Orthodox Church, Bartholomew I. ${ }^{21}$ In this document, "the two leaders expressed their joint beliefs in the goodness of creation, the centrality of the human person, and the belief that, at its core, the environmental crisis reflects moral failing." ${ }^{22}$ By suggesting goals to be pursued, the Venice Declaration "was an important step, both in ecumenical environmental dia$\log$ and in articulat[ing] a core set of principles that could serve as a basis for international dialog and, perhaps, even consensus." 23

Thus, the papacy of Pope John Paul II is noteworthy for the way in which it both articulated Catholic social thought on ecological questions far more than any prior papacy, and for the way in which it then acted on these teachings through the participation of the Holy See in diplomatic and ecumenical dialog on the international stage. It is in this context that Pope Benedict XVI began his papacy and in this context that his participation in ecological debate will take place. This is a climate in which it is expected first, that the Pope will continue to teach on and develop social teaching in environmental matters and, second, that the Holy See, under his leadership, will continue to intervene in relevant international discussions.

\section{The Ecological Thought and Themes of Pope Benedict XVI}

Upon first examination, it can be difficult to find lengthy, explicit writings of Pope Benedict XVI on ecological concerns. He has, of course, spent most of his public life and ministry as a theologian rather than a philosopher or politician. Thus, his writings have a decidedly different and more abstract tone from those of his predecessor, who wrote for a different audience and from a different perspective. However, a deeper examination of Pope Benedict XVI's past writings as Cardinal Ratzinger and his growing collection of public statements since his 2005 election to the papacy reveal his developing thought on ecological matters.

\footnotetext{
${ }^{21}$ Common Declaration of Pope John Paul II and Ecumenical Patriarch Bartholomew I (June 10, 2002), in KEENAN, supra note 2, at 149.

${ }^{22}$ Silecchia, supra note 2 , at 720.

${ }^{23} \mathrm{Id}$. at 721. See also Guntzel, supra note 2, at 10A (calling the Venice Declaration "a historic effort to cement the Christian obligation to environmental ethics" and noting that this document "went further than previous papal statements and issued a list of 'ethical goals"').
} 
Indeed, two decades ago when many ecological issues were garnering attention for the first time, and several years before the first papal document dedicated solely to environmental issues, then-Cardinal Ratzinger had already published a series of his homilies in a book called "In the Beginning ...": A Catholic Understanding of the Story of Creation and the Fall. ${ }^{24}$ Although the primary focus of this book was a theological explication of the Genesis creation accounts, it also explored the relationship between humanity, creation, and Creator, as well as the implications that those complex relationships have for environmental responsibility. In many of his other writings as well, spanning decades, Pope Benedict XVI has explored these issues in greater detail. In reviewing those writings and his papal statements to date, four significant and consistent themes appear. Exploration of these themes reveals the basic contours of Pope Benedict XVI's ecological vision, and lays the groundwork for the way in which the Church will intervene in environmental matters throughout his papacy.

\section{A. Creation Is a Vital Expression of the Creator}

It is impossible to understand the ecological thought of Pope Benedict XVI without exploring the bedrock principle of his theological writing on this topic. Throughout his writings, he makes clear that physical creation is the concrete way in which the splendor, ${ }^{25}$ power, ${ }^{26}$ and loving goodness ${ }^{27}$ of the Creator is manifested in this world. ${ }^{28}$ As he wrote,

\footnotetext{
${ }^{24}$ IN THE BEGINNING supra note 1.

${ }^{25}$ IN THE BEGINNING, supra note 1, at 3 (noting that the creation accounts in the book of Genesis generate " $a$ feeling for the immeasurability of creation and its Creator."); Pope Benedict XVI, Angelus, Les Combes, July 24, 2005 (speaking of the Transfiguration, and describing Mount Tabor as a place with "beauty in which the splendor of the Lord's divinity shone out."); Pope Benedict XVI, General Audience, Rome, October 26, 2005 (noting that Christ "receives honor from all of creation."); and Pope Benedict XVI, Letter of His Holiness Benedict XVI to His Holiness Bartholomew I, Ecumenical Patriarch on the Occasion of the Sixth Symposium on "Religion, Science, and the Environment," Focusing on the Amazon River, July 6, 2006 [hereinafter "Amazon River Letter"] ("II]n their majestic beauty, ... rivers and forests speak to us of God and of his grandiose work for humanity.").

${ }^{26}$ Joseph Cardinal Ratzinger, The Feast of Faith: Approaches to a Theology of the LituRgy (GRAHAM HARRISON, TRANS.) (1986) (hereinafter "FEAST OF FAith") (observing that the "theme of glorification" can be "found in the Old Testament in the context of the theology of creation."); IN THE BEGINNING, supra note 1, at 11 ("[T]his God of Israel was not a God like other gods, but... he was the God who held sway over every land and people. He could do this . . . because he himself had created everything in heaven and on earth."); Id. at 10 ("Israel always believed in the creator God, and this faith it shared with all the great civilizations of the ancient world. For, even in the moments when monotheism was eclipsed, all the great civilizations always knew of the Creator of heaven and earth."); Pope Benedict XVI, Apostolic Exhortation Sacramentum Caritatis,
} 
February 22, 2007, II35 [hereinafter "Sacramentum Caritatis"] ("God allows himself to be glimpsed first in creation, in the beauty and harmony of the cosmos. In the Old Testament we see many sights of the grandeur of God's power as he manifests his glory in his wondrous deeds.") and Pope Benedict XVI, General Audience, Rome, December 14, 2005 ("The purpose of the forceful images and expressions is to celebrate the Creator: 'If the greatness of the works created is immense,' said Theodore of Cyr, a Christian writer of the fifth century, "how much greater their Creator must be!").

27 See Joseph Cardinal Ratzinger, Seek That Which is Above 80-81 (Graham HarriSON, TRANS.) (1986) (hereinafter "SEEK THAT WHICH IS ABOVE") ("Pentecost should also be for us a festival of thanksgiving for Creation, a cause for reflection on the creative Reason which is also manifested in the beauty of the world as a creative Love."); JOSEPH CaRdinal Ratziner, God Is NEAR Us 52 (2003) (hereinafter "GoD Is NEAR Us") ("IA]ll our meals are alive with the goodness of God the Creator, and all thereby point toward this greatest feast of all, in which we receive no longer just earthly things, but the incarnate act of God's mercy."); Joseph Cardinal Ratzinger, GosPel, Catechesis, Catechism: Sidelights on the Catechism of the Catholic Church 44 (1997) [hereinafter "Gospel, CatECHESIS CATECHISM"] ("Because God is the Creator, he loves all creatures."); Pope Benedict XVI, Christmas Address to the Curia offering them His Christmas Greetings, December 22, 2005 (hereinafter "Christmas Address to the Curia") ("[T]here [is] the invitation not to see the world ... solely as raw material . . . but to try to discover in it 'the Creator's handwriting,' the creative reason and the love from which the universe was born and of which the universe speaks to us if we pay attention ..."); Pope Benedict XVI, General Audience, Rome, February 1, 2006 (calling God "a tender and loving King, concerned for all his creatures"); $I d$. ("The loftiest biblical prayer is in fact the celebration of the works of salvation, which reveal the Lord's love for his creatures."); Pope Benedict XVI, General Audience, Rome, March 7, 2007 ("[T] he entire cosmos reflects God's providential love and mercy."); Pope Benedict XVI, General Audience, Rome, February 8, 2006 (describing God as "a loving King who is attentive to his creatures"); $I d$. (declaring that "[i]n them [i.e., all creatures] are exalted the divine compassion, tenderness, fidelity and goodness which are extended to the whole humanity, involving every creature. ... God expresses his sovereignty by bending down to meet the frailest and most helpless of his creatures."); and Pope Benedict XVI, Message of the Holy Father Benedict XVI to the Youth of the World on the Occasion of the $22^{\text {nd }}$ World Youth Day 2007 (January 27, 2007) ("[T]he signs of divine love are clearly present in creatPơn'ö)seph Cardinal Ratzinger, Pilgrim Fellowship of Faith: The Church as CommunION 290 (Henry TAYLOR, TRANS.) (2005) (hereinafter "PilgRIM Fellowship") ("Christian faith appeals to reason, to the transparency of creation in revealing the Creator."); Joseph Cardinal Ratzinger, Truth and Tolerance: Christian Belief and World ReliGIONS 172 (HENRY TAYLoR, Trans) (2004) (hereinafter "Truth and Tolerance") ("Only the true God, whom we may perceive in nature by thinking things out, is worshiped. But he is more than nature. He comes before it and it is his creation."); JOSEPH CÁRDINAL Ratzinger, To Look on Christ: Exercises in Faith, Hope, and Love 27 (RoBert Nowell, TRANs.) (1991) (hereinafter "To LoOK ON CHRIST") ("We can 'see' God if we hearken to the voice of our essential nature, to the voice of creation, and let ourselves be led by this."); Seek That Which is ABove, supra note 27, at 117 ("God does not come to light in the artificial world of man-made things. So it is all the more necessary for us to leave our workaday world behind and go in search of the breath of creation in order that we may meet him and thus find ourselves."); Joseph Cardinal Ratzinger, The SPIRIT OF THE Liturgy 181 (Johan SAWARd, Trans.) (2000) (hereinafter "SPIRIT of THE LiturGy") ("When we open our eyes, we can read the message of Christ in the language of the universe, and conversely, Christ grants us understanding of the message of creation."); IN THE 
"the same God who speaks to the whole world in the divine word and its radiance is the God who witnesses to himself in the sun, moon, and stars in the beauty and fullness of creation."29

It is highly likely that all ecological teachings of Pope Benedict XVI will emerge directly from his creation theology. As both a gift from ${ }^{30}$ and an expression of the Creator, the natural world is deserving of, and demands the respect of, humanity. Indeed, in his very first encyclical letter, Deus Caritas Est, Pope Benedict XVI wrote, "[T] which we live has its source in God and was created by him. ... [T]he whole world comes into existence by the power of his creative word. Consequently, his creation is dear to him, for it was willed by him and 'made' by him." ${ }^{31}$ As "a sphere for the exercise of God's will,"32 creation is viewed by Pope Benedict XVI as important if for no other reason than that it is the locus chosen by the Creator in which salvation and redemption will occur. ${ }^{33}$

BEGINNING, supra note 1, at 3 (stating that the creation account in the Book of Genesis "stirs the heart from afar with its beauty and dignity and gives it an inkling of the mystery of eternity."); Id. at 24 ("God himself shines through the reasonableness of his creation."); Pope Benedict XVI, General Audience, Rome, May 18, 2005 ("[W]ith impassioned insistence, the 'name of the Lord' resounds at the centre of the prayer of adoration. All being and all time ... are involved in a single action of grace. It is as if a ceaseless breath were rising from earth to heaven to praise the Lord, Creator of the universal and King of history."); and Pope Benedict XVI, Homily of His Holiness Benedict XVI, Rome, February 5, 2006 ("[T]his capacity to recognize the voice and manifestation of God in the beauty of creation belongs to all believers regardless of their religion.").

${ }^{29}$ Gospel, Catechesis, Catechism, supra note 27, at 86.

30 Joseph Cardinal Ratzinger, God and the World: Believing and Living IN OUR Time 100 (HENRY TAYLOR, TRANS.) (2002) (hereinafter "GOD AND THE WORLD") ("IC]reation is an act of total freedom, and that too is something the Christian tradition . . . has always emphasized, that God did not have to undertake creation, but did so quite freely.").

${ }^{31}$ Pope Benedict XVI, Deus Caritas Est, TI 9, December 25, 2005 (hereinafter "Deus Caritas Est"), available at www.vatican.va.

${ }^{32}$ Pilgrim Fellowship, supra note 28, at 134.

${ }^{33}$ See IN THE BEGINNING, supra note 1, at 28 ("The creation accounts of all civilizations point to the fact that the universe exists for worship and for the glorification of God."); $I d$. at 9 ("T]he theme of creation is not set down once for all in one place; . . it accompanies Israel throughout its history."); Id. at 30 ("God created the universe in order to become a human being and pour out his love upon us and to invite us to love him in return."); Joseph Cardinal Ratzinger, A New Song For The Lord 66 (Trans.: Martha MATESICK) (1996) (hereinafter "A NEW SONG") ("The resurrection connects the beginning and the end, creation and restoration."); $I d$. at 69 ("[T] tacle where human beings then accidentally became involved, but... right from the start creation came to be so that there would be a place for the covenant."); THE SPIRIT OF The LitURGY, supra note 28, at 27 ("Creation looks toward the covenant, but the covenant completes creation and does not simply exist along with it."); $I d$. at 108 
This theological centrality of the created world leads to a deep conviction that it is to be respected and cherished simply out of love for God. Pope Benedict XVI has written that "[i]f creation is meant to be a space for the covenant, the place where God and man meet one another, then it must be thought of as a space for worship."34 Clearly, that which is a "space for worship" warrants respect and reverence. Conversely, failure to show proper respect for that which God has created is disrespectful and carelessly irreverent to the Creator himself.

In addition, Pope Benedict XVI has spoken eloquently of the unique ability of nature to draw humanity closer to God:

In contact with nature, individuals rediscover their proper dimension, they recognize that they are creatures but at the same time unique, "capable of God" since they are invariably open to the infinite. Driven by the heartfelt need for meaning that urges them onwards, they perceive the mark of goodness and divine Provi-

("The cosmos finds its true meaning in the Firstborn of creation. . . From him comes the assurance that the adventure of creation ... does not end up in absurdity and tragedy but, throughout all its calamities and upheavals, remains something positive."); Id. at 24 ("[F]aith in redemption cannot be separated from faith in the Creator."); To LOOK ON CHRIST, supra note 28, at 65 ("All our hopes find their culmination in the one hope: thy kingdom come, thy will be done on earth as it is in heaven. The earth will become like heaven, it will itself become heaven."); Pope Benedict XVI, General Audience, Rome, September 7, 2005 ("Christ is ... the 'firstborn' of 'all creation.' Christ is before all things because he has been begotten since eternity, for 'all things were created through him and for him.' The ancient Jewish tradition also says that 'the whole world was created in view of the Messiah."'); Pope Benedict XVI, General Audience, Rome, May 11, 2005 ("[C]hrist leads history wisely towards the dawn of the new heaven and the new earth."); Pope Benedict XVI, General Audience, Rome, December 14, 2005 ("God knows everything and is present beside his creature who cannot elude him."); Id. ("Every sphere of space, even the most secret, contains God's active presence."); GOD AND THE WORLD, supra note 30, at 113 ("With the creation of the earth, so to speak, a workshop was provided for the Torah."); Id. ("The world is created in order to provide a setting for the covenant by which God binds himself to man."); Id. at 114 ("The world is, so to speak, the physical embodiment of the idea of the original thought God carried within him and which, through this embodiment has been made into a historical setting for the relationship between God and his creation."); IN THE BEGINNING, supra note 1, at 85 ("Only when creation and covenant come together can either creation or covenant be realistically discussed. The one presupposes the other."); and Pope Benedict XVI, Angelus, Rome, December 24, 2006 ("Jesus . . . makes us feel at home on this earth, sanctified by his presence. He asks us . . to make it a home in which all are welcome.")

See also Seek That Which Is Above, supra note 27, at 82:

Some time ago it might have seemed highly anthropomorphic, not to say anthropocentric when Paul says that creation waits with eager longing for the revelation of the sons of God. . . . But today we can sense the groaning of creation under the feet of those who no longer have anything to do with God and want to delete him from the world. Creation cries out to the sons of God, for it was created with a view to the Covenant.

${ }^{34}$ SPIRIT OF THE LitURGY, supra note 28 , at 26. 
dence in the world that surrounds them, and open themselves almost spontaneously to praise and prayer. . . [L]ove for nature . . . blossoms in gratitude to God. ${ }^{35}$

Again, this insight is theological rather than practical. Nevertheless, this provides a direct spiritual rationale for creation care repeated frequently in the work of Pope Benedict XVI.

Pope Benedict XVI has often lamented what he perceives to be a lack of attention paid by modern theologians to the value of the created world. He observes that, "[p]aradoxically ... the creation account is noticeably and nearly completely absent from catechesis, preaching, and even theology." ${ }^{36}$ He also expresses regret that "the theme of creation has been far removed from central to contemporary theological thinking. In fact, the theme of creation has played only a limited role in the theological discussion of recent years, indeed decades. It has seemed a question devoid of concrete anthropological importance. ${ }^{37}$ In the view of Pope Benedict XVI, a valid and accurate understanding of environmental obligations does not exist absent a fuller comprehension of this question. ${ }^{38}$ The link between respect for God and respect for

${ }^{35}$ Pope Benedict XVI, Angelus, Les Combes, July 17, 2005. See also JosEPH CARDINAL, Ra'tziner \& Christopher Schönborn, Introduction To The Catechism Of The Catholic CHURCH 36 (1994) ("The catechism, together with Traditions, is aware that reason, dulled by sin, tends to close in upon itself. Yet, it does not forget that reason has not lost its native capacity to perceive the creator and his creation."), and Pope Benedict XVI, General Audience, Rome, December 20, 2006 ("Creation itself . . leads us to discover and recognize the One who must come.").

${ }^{36}$ In THE Begrinning, supra note 1, at ix. See also Id., at x (decrying "the practical abandonment of the doctrine of creation in influential modern theology."); Id. at xii ("With such an 'existential' reduction of the creation theme ... there occurs a huge (if not total) loss of the reality of the faith whose God no longer has anything to do with matter."); and Id. at 82 ("If we want to reappropriate faith in creation with its basic content and direction, then we must first bring it out of the obscurity ... in ... our current theological situation.").

${ }^{37} I d$. at 80 .

${ }^{38}$ See, e.g., A NeW SoNG, supra note 33 , at 65 :

[T]heologians often have a kind of phobia about treating the topic of creation. This, however, leads to the degeneration of faith into a kind of parochial ideology, to the worldlessness of faith and the godlessness of the world, which is life-threatening for both. Where creation shrinks to the world around us, human beings and the world are out of kilter. But, there is a complaint resounding ever more audibly out of this creation which has degenerated into mere environment, and precisely this complaint should tell us once more that the creature is in fact reaching out for the appearance of the children of God.

See also Amazon River Letter, supra note 25 ("The duty to emphasize an appropriate catechism concerning creation, in order to recall the meaning and religious significance of protecting it, is closely connected with our duty as Pastors and can have an important impact on the perception of the value of life itself as well as on the satisfactory solution of the consequent inevitable social problems."). 
his creation is, for Pope Benedict XVI, the source and foundation of ecological ethics. All else will build on this.

\section{B. Liturgical Life and Natural Life Are Closely and Fundamentally Linked}

Although many have written of the links between liturgical life and the rhythms and symbols of the natural world, few do so as eloquently as has Pope Benedict XVI who repeatedly writes that "[c]reation is designed in such a way that it is oriented to worship." ${ }^{\text {9 }}$ As he wrote, "[w]e need to be reminded that liturgy involves the cosmos-that Christian worship is cosmic worship. In it we pray and sing in concert with everything 'in heaven, on earth, and under the earth'; we join in with the praise rendered by the sun and the stars. ${ }^{40}$ In his writings, he explores the many ways in which religious life and Christian symbols evoke the created, natural world. In this way, he expresses deep respect for the ancient roots of Christian worship in the Old Testament, where religious ritual was inextricably intertwined with the rhythms of nature. ${ }^{41}$ These liturgical linkages do not lead directly to an obvious environmental policy, but they reflect two important elements of Pope Benedict XVI's thought on ecological questions.

First, the mere act of tying creation and the natural world to religious life expresses a profound belief in the innate goodness and, indeed, holiness of that creation. The intimate connection between mundane natural events and the most intricate of theological mysteries leaves one with the unavoidable conclusion that there is a profound goodness in that nature. ${ }^{42}$ This connection can be seen in the liturgy ${ }^{43}$ the symbols of worship, ${ }^{44}$ Scriptural references, ${ }^{45}$ the parables of Christ, ${ }^{46}$ sac-

\footnotetext{
${ }^{39}$ In The Beginning, supra note 1 , at 27.

40 The Feast of Faith supra note 26 , at 143.

${ }^{41}$ See Joseph Cardinal Ratzinger, Milestones: Memoirs 1927-1977, 17 (Trans.: ErASMo LeIvo-MERIKAKIS) (1998) (hereinafter "Milestones") ("The life of farmers was still organically structured in such a way that it enjoyed a firm symbiosis with the faith of the Church: birth and death, weddings and illnesses, sowing time and harvest timeeverything was encompassed by the faith."); Pope Benedict XVI, General Audience, Rome, August 17, 2005 ("[T]he horizon of the Psalm opens to the festive harvest, a symbol of joy born from the freedom, peace, and prosperity that are fruits of the divine blessing."); and The SPIRIT OF The LiTURGY, supra note 28, at 105 ("In the spring the farmer sows seeds for autumn, in autumn for the coming year. Sowing seeds always points to the future. It belongs to the waning year, but also to the waxing year, for the waning year also points to a new future. In both seasons the mystery of hope is at work....").

${ }^{42}$ Pope Benedict XVI, however, does not over-idealize nature or ignore its potential for harm. See GoD AND THE WorLD, supra note 30, at 79 ("It is in fact one of the great riddles of creation that there seems to be a law of brutality."); Pope Benedict XVI,
} 
General Audience, Rome, August 24, 2005 (expressing sympathy to "the regions of Europe hit in the past few days by floods or fires, which have unfortunately claimed may victims and caused immense damage. Many families have been left homeless and hundreds of people must face tragic hardships."); Pope Benedict XVI, Angelus, Castel Gandolfo, September 4, 2005 ("IW]e have all been distressed at the disaster caused by a hurricane in the United States of America, especially in New Orleans. I would like to assure you of my prayers...."); JoSEPH RATZINGER, FAITH AND THE Future 84 ( KOSELVERLAG, TRANS.) (1971) (hereinafter "FAITH \& THE FUTURE") ("Anyone who grew up in the pre-technical age is unlikely to be tempted to fall for the romanticism of nature."); and Pope Benedict XVI, General Audience, Rome, June 22, 2005 ("God has saved his people from every evil whether they were threatened by enemies who rose against them, by raging waters about to engulf them, or by beasts of prey, the Lord was by their side.").

${ }^{43}$ See, e.g., THE FEAST OF FAITH, supra note 26, at 135 ("Liturgy is not the private hobby of a particular group; it is about the bond which holds heaven and earth together; it is about the human race and the entire created world."); THE SPIRIT OF THE LiTURGY, supra note 28, at 53 ("Christian worship is surely a cosmic liturgy which embraces both heaven and earth."); $I d$. at 125 ("In the liturgy, the curtain between heaven and earth is torn open and we are taken up into a liturgy that spans the whole cosmos."); IN THE BEGINNING, supra note 1, at 28 ("Creation exists for the sake of worship."); and Sacramentum Caritatis, supra note 26, at I[35 ("The beauty of the liturgy is part of this mystery; it is a sublime expression of God's glory and, in a certain sense, a glimpse of heaven on earth.").

${ }^{44}$ Inaugural Homily, supra note 4 ("The symbolism of the Pallium is . . concrete: the lamb's wool is meant to represent the lost, sick, or weak sheep which the shepherd places on his shoulders and carries to the water of life.").

${ }^{45}$ Pope Benedict XVI, General Audience, Rome, June 8, 2005 ("Today we feel a wind; the wind in Sacred Scripture is a symbol of the Holy Spirit."); Pope Benedict XVI, Angelus, March 5, 2006 ("The image of the desert is a very eloquent message of the human condition."); GoD Is NEAR Us, supra note 27, at 25 ("[T]he well emerges as the image for life itself, right up to the well of Jacob, at which Jesus reveals himself as the wellspring of true life, the one for which the deepest thrust of mankind has been waiting. The well . . . becomes a sign for the mystery of Christ, who offers us the water of life and from whose opened side flow blood and water."); Pope Benedict XVI, Homily of His Holiness Benedict XVI for XXI World Youth Day, Rome, April 9, 2006 [hereinafter "2006 World Youth Day Homily"] ("The Cross is the broken bow, in a certain way, God's new, true rainbow which connects the heavens and the earth and bridges the abysses between the continents."); Pope Benedict XVI, LeT God's Light Shine ForTh: The SPIRITUal Vision of Pope Benedict XVI 160 (Robert Moyniman, Ed.) (2005) (hereinafter "SPIRITUAL VISION") ("The cosmic symbol of the rising sun expresses the universality of God above all particular places."); Pope Benedict XVI, Address of the Holy Father, Rome, November 30, 2006 ("The Christian message, like the grain of wheat ... fell on this land and bore much fruit."); Pope Benedict XVI, Homily of His Holiness Benedict XVI, Cappella Papale, December 8, 2005 ("God has impressed his own image, the image of the One who follows the lost sheep even up into the mountains and among the briars and thorn bushes of the sins of this world."); Pope Benedict XVI, Homily of His Holiness Pope Benedict XVI at the Funeral Mass for Cardinal Giuseppe Caprio, Rome, October 18, 2005 (calling Christ "the sun that never sets."); Pope Benedict XVI, Homily of His Holiness Benedict XVI, Rome, December 31, 2006 (referring to Christ as "the new Sun rising on the horizon of humanity"); Pope Benedict XVI, General Audience, April 26, 2006 ("Tradition is the living river that links us to the origins, the living river in which the origins are ever present, the great river that leads us to the gates of eternity."); Pope Benedict XVI, General Audience, Rome, December 21, 2005 ("The Saviour awaited 
ramental life, ${ }^{47}$ the observance of the weekly Sabbath,${ }^{48}$ the liturgical calendar, ${ }^{49}$ church art and architecture,${ }^{50}$ liturgical music, ${ }^{51}$ and the Eucharist itself. ${ }^{52}$

by the people is hailed as the 'Rising Star'; the star that points out the way to men and women and guides them as they journey through the shadows and dangers of the world toward the salvation promised by God and fulfilled in Jesus Christ."); and Pope Benedict XVI, Address of His Holiness Benedict XVI to the Participants at the Meeting Promoted by the Pontifical Council 'Cor Unum', Sala Clementina, January 23, 2006 ("Light and love are one and the same. They are the primordial creative powers that move the universe.").

${ }^{46}$ Inaugural Homily, supra note 4 ("For the Fathers of the Church, the parable of the lost sheep, which the shepherd seeks in the desert, was an image of the mystery of Christ and the Church. The human race, everyone of us-is the sheep lost in the desert which no longer knows the way.") and Pope Benedict XVI, Homily of His Holiness Benedict XVI at the Holy Mass for the Ordination to the Priesthood of 15 Deacons of the Diocese of Rome, Rome, May 7, 2006 (exploring more fully the parable of the sheep).

${ }^{47}$ See, e.g., Joseph Cardinal Ratzinger, Principles of Catholic Theology: Bullding Stones for a Fundamental Theology 29 (Mary Francis McCarthy, S.N.D, trans.) (1987) (hereinafter "Principles of CATHOLIC Theology") ("In the sacrament, .. . matter and word belong together, and precisely this is the source of its uniqueness. If the material sign expresses the unity of creation, the assumption of the cosmos into religion, the word, for its part, signifies the assumption of the cosmos into history."); THE FEAST OF FAITH, supra note 26, at 71 ("The theology of creation and the theology of the resurrection ... demand that prayer should be expressed in a bodily form, involving all the dimensions of bodily expression."); Pope Benedict XVI, Homily of His Holiness Benedict XVI, Rome, January 7, 2007 (saying of Baptism, "Baptism is not only a word, it is not only something spiritual but also implies matter. All the realities of the earth are involved. . . . Water is the element of fertility. Without water there is no life. Thus, in all the great religions water is seen as the symbol of motherhood, of fruitfulness."); and Pope Benedict XVI, Homily of His Holiness Benedict XVI, Sistine Chapel, January 8,2006 ("Water is the symbol of life.").

${ }^{48}$ See, e.g., THE SPIRIT OF THE LiTURGY, supra note 28 , at 25 ("Creation moves toward the Sabbath, to the day on which man and the whole created order participates in God's rest, in his freedom."); IN THE BEGINNING, supra note 1, at 27 ("Creation is oriented to the Sabbath, which is the sign of the covenant between God and humankind."); A NEw SoNG FOR THE LORD, supra note 33, at 65 ("[T]he connection between Sunday and creational faith becomes evident here... The Old and New Testaments cannot be separated, especially not in the interpretation of Sunday. Creation and faith cannot be detached from each other, least of all at the core of the Christian profession."); Id. at 69 ("[I]t is fundamental that the Sabbath is part of the story of creation. One could actually say that the metaphor of the seven-day week was selected for the creation account because of the Sabbath. By culminating in the sign of the covenant, the Sabbath, the creation account clearly shows that creation and covenant belong together from the start."); and Joseph Cardinal Ratzinger, Seeking God's Face 13 (Trans.: David Smith and Robert Cunningham) (1982) (hereinafter "SEEKING GOD's FACE") ("The eighth day is also the day of His resurrection and at the same time the day of creation. God's creation does not come to nothing. It is always moving toward the resurrection.... In the midst of passing time, there is always a new beginning.").

49 Cardinal Joseph Ratzinger, Journey Towards Easter 55-56 (Trans. Mary Groves O.S.B.) (1987) (hereinafter "JOURNEY TOWARDS EASTER") (“[W]e receive the year from the 
hand of God, receive our time from the Creator and Redeemer, and confide sowing and harvesting to his goodness, thanking him for the fruit of the earth, and our work. ... [T]hrough our prayer, creation enters into the Eucharist, has part in the praise of God."); IN THE BEGINNING, supra note 1, at 31 ("[E]very seventh year is also a Sabbath, during which earth and human beings rest . . . The earth is to be received back from the creating hands of God, and everyone is to begin anew."); THE SPIRIT OF THE LITURGY, supra note 28, at 109 ("The birthday of St. John the Baptist takes place on the date when the days begin to shorten, just as the birthday of Christ takes place when they begin again to lengthen. ... The close interweaving of incarnation and resurrection can be seen precisely in the relation, both proper and common, that each has the rhythm of the sun and its symbolism."); GOD Is NEAR Us, supra note 27, at 61 ("[T]he Resurrection took place on the first day of the week. The Jews saw this as the day on which the world was created. For Jesus' disciples, it became the day on which a new world began, the day when with the breaking of the bonds of death, the new creation had its beginning."); Pope Benedict XVI, General Audience, Rome, December 21, 2005 ("[T] Christmas coincides with the days of the winter solstice, after which the daylight time gradually lengthens, in accordance with the sequence of the seasons. This helps us understand better the theme of light that overcomes the darkness."); Christmas Address to the Curia, supra note 27 ("Christmas is a feast of light and peace."); and Pope Benedict XVI, General Audience, Rome, March 1, 2006 (saying, of Lent, "[I]n this liturgical season, the People of God from the earliest times have drawn abundant nourishment from the Word of God to strengthen their faith, reviewing the entire history of creation and redemption.").

${ }^{50}$ ThE FEAST OF FAITH, supra note 26, at 143:

[I]n church architecture, ... we should see to it that churches are not designed merely with human utility in mind, but that they stand in the cosmos, inviting the sun to be a sign of the praise of God and a sign of the mystery of Christ for the assembled community. A rediscovery of the value of the Church building's eastward orientation would help, it seems to me, in rediscovering a spirituality which embraces the dimension of creation.”

See also The SPIRIT OF The LitURgy, supra note 28, at 132 ("Sacred art finds its subjects in the images of salvation."); and Sacramentum Caritatis, supra note 26, at II41 ("The profound connection between beauty and the liturgy should make us attentive to every work of art placed at the service of the celebration.").

${ }^{51}$ See, e.g., THE SPIRIT OF the LitURGy, supra note 28 , at 152; Id. ("All our singing is a singing and praying with the great liturgy that spans the whole of creation."); and Id. at 221-23 (describing in detail the natural elements present in Christian liturgy). See also Pope Benedict XVI, Address of His Holiness Benedict XVI at the Concert to Commemorate the Election of the Holy Father, April 21, 2006 ("[M] usic also helps us grasp the most intimate nuances of human genius, in which is reflected something of the incomparable beauty of the Creator of the universe.").

${ }^{52}$ The SPIRIT OF THE LiTURGY, supra note 28 , at 173 :

The elements of the earth are transubstantiated, pulled, so to speak, from their creaturely anchorage, grasped at the deepest ground of their being, and changed into the Body and Blood of the Lord. The New Heaven and the New Earth are anticipated.

See also id. at 173 ("God himself acts and does what is essential. He inaugurates the new creation, makes himself accessible to us, so that through the things of the earth, through our gifts, we can communicate with him in a personal way."); THE FEAST OF FAITH, supra note 26, at 135 (observing that Christ "willed to give himself in the grain of the wheat and the fruit of the vine."); Id. at 136 ("[T]he Christian feasts are also 


\section{Indeed, Pope Benedict XVI began the October 2005 Synod of Bishops} with a homily replete with references to the profound link between the Eucharist and nature:

In Sacred Scripture, bread represents all that human beings need for their daily life. Water makes the earth fertile: it is the fundamental gift that makes life possible. Wine, on the other hand, expresses the excellence of creation and gives us the feast in which we go beyond the limits of our daily routine. . . . So it is that wine and with it the vine have also become images of the gift of love. ${ }^{53}$

With his extensive theological reflections on these linkagesreflections that span decades-Pope Benedict XVI has built a very wellcrafted body of thought that links the natural world to religious worship. If religious worship is oriented toward the good, and natural cre-

involved with the rhythm of the year, the rhythm of seedtime and harvest. How could it be otherwise in a liturgy which has at its center the sign of bread, fruit of the earth and heaven? Here, this fruit of the earth, bread, is privileged to be the bearer of him in whom heaven and earth ... have become one."); Id. at 134 ("The world is thus declared to be the realm of God's creative word; matter is subordinated to the power of his Spirit. For matter too is his creation and hence the sphere of his gracious power. Ultimately, we receive the very bread of the earth from his hands."); Sacramentum Caritatis, supra note 26, at I44 ("II]n the bread and wine that we bring to the altar, all creation is taken up by Christ the Redeemer to be transformed and presented to the Father."); Id. at I92 ("The Christian people, in giving thanks to God through the Eucharist, should be conscious that they do so in the name of all creation, aspiring to the sanctification of the world and working intensely to that end."); and $I d$. ("[D]uring the presentation of the gifts, the priest raises to God a prayer of blessing and petition over the bread and wine, 'fruit of the earth,' 'fruit of the vine' and 'work of human hands.' With these words, the rite not only includes ... all human efforts and activity, but also leads us to see the world as God's creation, which brings forth everything we need for our sustenance.").

${ }^{53}$ Pope Benedict XVI, Homily of His Holiness Benedict XVI at the Opening of the $11^{\text {th }}$ Ordinary Assembly of the Synod of Bishops, Rome, October 2, 2006 [hereinafter "Synod Opening Homily."]. See also Id. ("Christ himself became the vine, and this vine always bears good fruit."). This link was explored more fully by other participants at the Synod. See John L. Allen, Jr., Coverage of Bishops' Synod on the Eucharist, Report \#5: Environment, Social Justice Emerge as Eucharistic Themes, National CATHOLIC REPORTER, October 6, 2005 (www.nationalcatholicreporter.org/word/sb100605.htm) ("[Q]uietly a number of other surprising themes are emerging, including the connection between the Eucharist and ecology. Two bishops from the developing world have insisted that if the Eucharist is the summit of all creation, then it necessarily implies concern for the integrity of the environment."). A full text of the conversation of this topic can be found at Synodus Episcoporum Bulletin-XI Ordinary General Assembly of the Synod of Bishops: The Eucharist: Source and Summit of the Life and Mission of the Church, 06-04.10.2005 (An unofficial English transcript from the Holy See Press Office is available on line at www.vatican.va/news_services/press/sinodo/documents/bollettino_21_xi-ordinario). This theme was reiterated when Pope Benedict XVI commented, "The relationship between the Eucharist and the cosmos helps us to see the unity of God's plan and to grasp the profound relationship between creation and the 'new creation' inaugurated in the resurrection of Christ, the new Adam." Sacramentum Caritatis, supra note 26, at II92. 
ation is visible in religious worship, then clearly there is a good in nature to which Pope Benedict XVI's work consistently refers. As he explains, "man's own being is insufficient for what he has to express, and so he invites the whole of creation to become a song with him."

Second, and more subtlety, it is the cyclical, repetitive characteristic of nature-and not the dramatic beauty of rare events-that gets the most attention from Pope Benedict XVI. This is especially apparent in his writings that link creation to the cyclical and repetitive nature of liturgical life Although on occasion his writings venture briefly into the exultation of nature's dramatic splendor, his typical pattern is one of greater restraint, in which it is the more mundane order of creation that earns his awe. This suggests that it is nature's often underappreciated order, stability, and logic that is the truly valuable part of creation. ${ }^{55}$ By definition, then, a disruption of that rhythm and logic through abuse of the environment would run contrary to the order and rhythm created by God and enshrined at the very heart of liturgical life. As he wrote, "[w]e live in a world created by God along rational lines, and he has entrusted this world to us so that we may rethink the

\footnotetext{
${ }^{54}$ The SPIRIt of The Liturgy, supra note 28, at 136.

55 See Joseph Cardinal Ratzinger, A Turning Point For Europe? 38 (Trans. Brian McNeIL, C.R.V.) (1994) (hereinafter "A TuRning PoINT For EuRoPE"):

[N]ature is not-as is asserted by a totalitarian scientism-some assemblage built up by chance and its rules of play, but is rather a creation. A creation in which the Creator Spiritus expresses himself. This is why there are not only natural laws in the sense of physical functions: the specific natural law is itself moral law. Creation itself teaches us how we can be human in the right way.
}

See also PILGRIM Fellowship of FAITH, supra note 28, at 288 ("[T] creation story] moves toward the Sabbath is trying to make clear that creation has an inner basis and purpose. It is there in order that the covenant may come to be in which God freely gives his love and receives the response of love."); IN THE BEGINNING, supra note 1, at 17 ("The reasonableness of creation derives from God's Reason, and there is no other really convincing explanation."); $I d$. at 23-24 ("In what is most vast, in the world of heavenly bodies, we see revealed a powerful Reason that holds the universe together. And we are penetrating ever deeper into what is smallest, into the cell and into the primordial units of life; here, too, we discover a Reason that astounds us."); Sacramentum Caritatis, supra note 26, at 192 ("The world is not something indifferent, raw material to be utilized simply as we see fit. Rather, it is part of God's good plan."); and Seer That Which Is ABove, supra note 27, at 30:

Not everything is appropriate at all times: the human being needs a rhythm, and the year gives him this rhythm, both through creation and through the history which faith sets forth in the yearly cycle. This brings us to the Church's year, which enables man to go through the whole history of salvation in step with the rhythm of creation, simultaneously ordering and purifying the chaotic multiplicity of our nature. Nothing human is omitted from this cycle of creation and history. 
thoughts of his reason with our reason, and learn to govern, order, and shape the world according to his thoughts."56

It may be more typical-and effective-for ecologists or environmentalists to garner support by drawing the attention of an often apathetic public to a dramatic or beautiful element of the natural world. However, Pope Benedict XVI's writings speak of the routine, cyclical patterns of the natural order that warrant respect and protection. ${ }^{57} \mathrm{He}$ has written:

What we had previously celebrated-namely, that through faith in creation the world has been demythologized and made reasonable; that sun, moon, and stars are no longer strange and powerful divinities but merely lights; that animals and plants have lost their mystic qualities: all this has become an accusation against Christianity. Christianity is said to have transformed all the power of the universe, which were once our brothers and sisters, into utilitarian objects for human beings, and in so doing it has led them to misuse plants and animals and in fact all the world's powers for the sake of an ideology of progress that thinks only of itself and cares only for itself. What can be said in reply to this? The Creator's directive to humankind means that it is supposed to look after the world as God's creation, and to do so in accordance with the rhythm and the logic of creation. ${ }^{58}$

This line of thought is likely to garner greater attention as scientists and ecologists learn ever more about the large scale rhythms and cycles of the created world, and the long-term harms that can arise from the careless disruption of that order. ${ }^{59}$

\section{Technology Holds Both the Capacity to Aid and to Destroy the Earth's Well-Being}

A third theme woven throughout Pope Benedict XVI's writings is a warning about the ability of technology to be misused, with harmful

56 A NEw Song, supra note 33, at 38. See also Journex Toward EAster, supra note 49, at 92 ("[T] he world has to be continually defended from chaos, creation must always be protected and made new.").

${ }^{57}$ Pope Benedict XVI, Homily of His Holiness Benedict XVI, Rome, December 31, 2006 (discussing "the solar cycle with its rhythms").

${ }^{58}$ IN The Beginning, supra note 1, at 33-34 (emphasis added).

59 See GoD AND THE WoRLD, supra note 30, at 73 ("[C]reation is indeed a mystery, and the more we know about it, the more physics is able to see into the delicate structure of matter, the more mysterious it appears."); and IN THE BEGINNING, supra note 1, at 34:

[T] he world is to be used for what it is capable of and for what it is called to, but not for what goes against it. Biblical faith implies in the first place that human persons are not closed in upon themselves: they must always be aware that they are situated in the context of the body of history, which will ultimately become the body of Christ. Past, present, and future must encounter and penetrate one another in every human life. Our age is the first to experience that hideous narcissism that cuts itself off from both past and future and that is preoccupied exclusively with its own present. 
environmental consequences. Pope Benedict XVI's writings express an ambivalent $^{60}$-or, even, pessimistic-outlook toward technology in the ecological context, as well as in other realms:

Progress has always been a word with a mythical ring. It continues to be portrayed insistently as the norm of political activity and of human behavior in general and as their highest moral qualification. Anyone who looks even at only the last hundred years cannot deny that immense progress has been made in medicine, in technology, and in the understanding and harnessing of the forces of nature, and one may hope for further progress. At the same time, however, the ambivalence of this progress is obvious. Progress is beginning to put Creation-the basis of our existence-at risk; it creates inequality among human beings, and it generates ever new threats to the world and humanity. This makes moral controls of progress indispensable. ${ }^{61}$

While he acknowledges that there are undeniable advantages to human technological progress, ${ }^{62}$ Pope Benedict XVI's writings indicate an urgent wariness about the misuse of technology and the harm this may pose to the environment in two distinct ways. ${ }^{63}$ First, and most directly, this misuse has a physical component that can wreck havoc with the natural world. However, it also has a moral and attitudinal component that can be equally destructive for the long term welfare of the environment. As Pope Benedict XVI warns, "[w]e live in a time in which science and technology offer extraordinary possibilities for improving

${ }^{60}$ See, e.g., Joseph Cardinal Ratzinger, Christianity and the Crisis of Cultures 29 (Trans.: BRIAN MCNeIL) (2005) (hereinafter "Crisis of Cultures") (observing that "scientific rationality... has given us both enormous possibilities and enormous menaces.").

61 Joseph Cardinal Ratzinger, Values In A Time Of Upheaval 25 (2006) (hereinafter "Values In A Time Of Upheaval").

${ }^{62}$ See, e.g., Joseph Ratzinger, Theological Highlights of Vatican II, 159-60 (Trans: Henry Traub, S.J.) (1966) (hereinafter "Theological Highlights of Vatican II"):

The connection between the Christian and technology does not come through sacralization of technology, but only through the idea of love seen without illusions. Technological service becomes Christian when it is motivated by a service which seeks to humanize men-that is, when it serves love. Then, and only then, does technological progress serve Christianity and only then is it really progress. The Christian message cannot have as its purpose the glorification of the technological.

See also FAITH AND the Future, supra note 42, at 86-87 ("[W]e must understand the striking optimism with which the Vatican Council viewed the technological age and judges its advances to be realizations of the primeval commission to man to subdue the whole earth."); Id. at 84 ("Technology creates new opportunities for humanity.").

63 The urgency of this question is expressed in A TuRning PoINT For Europe, supra note 55, at 95, where then-Cardinal Ratzinger notes, "The resistance of creation to its manipulation by men has become a new factor in the intellectual situation in the last decade. It is impossible to evade the question of the limits of science and of the criteria it must follow." 
everyone's existence. But a distorted use of this power can seriously and irreparably threaten the destiny of life itself." ${ }^{\prime 44}$

Pope Benedict XVI fears the obvious physical harm to the environment that is posed by misused technology. This is a concern shared by many secular ecologists as well. He warns against a world in which the distinctions between the good uses of technology and the destructive ones have been blurred. Reflecting on modern developments, he observes that "[ $t]$ he resistance of creation to its manipulation by men has become a new factor in the intellectual situation in the last decade. It is impossible to evade the question of the limits of science and of the criteria it must follow." ${ }^{\text {"W5 }}$ With much concern, he notes that the world is now at an unprecedented point in which humanity is capable of widespread ecological destruction, ${ }^{66}$ and asks "how are we to know when technology is appropriate to the claims of creation and when it is becoming destructive?"67 That destructive capability, brought on by technological advances, is a frightening one-and one the pope views as a

\footnotetext{
${ }^{64}$ Pope Benedict XVI, Address of His Holiness Benedict XVI to the Italian Christian Workers' Associations, Clementine Hall, January 27, 2006.

${ }^{65}$ A Turning Point For Europe, supra note 55, at 95.

${ }^{66}$ See, e.g., TRUTH AND TOleRANCE, supra note 28 , at 158 :

[I]f we think of the way science had made use of producing ever more frightful means for the destruction of men and of the world, then it is obvious that there is such a thing as science that has taken a pathological form: science becomes pathological and a threat to life when it takes leave of the moral order of human life, becomes autonomous, and no longer recognizes any standard but its own capabilities.
}

See also Joseph Cardinal Ratzinger, Many Religions-One Covenant: Israel, The Church, And The World 93-94 (Trans. Graham Harrison) (1991) (hereinafter "Many RELIGIONS") ("Now, therefore, at a time when mankind has acquired the ability to destroy itself and its planet, it is clear that religions share a common responsibility to overcome this temptation"); A NEw SoNG, supra note 33, at 37 (describing "fear of the ecological threat to the roots of life caused by the unstoppable momentum of a technology that was created by humans as their power over nature, but now threatens to become a force turned against them, a power that has slipped out of their control and dominates them rather than being the means by which they dominate."); GoD AND THE WoRLD, supra note 30, at 119 ("A gnat can do what is in it to do, no more and no less. Man, however, with all humanity, holds in his hands the entire sum of hidden human potential. He can in the end develop methods of destruction that are beyond the capability of any other living thing."); FAITH AND THE FUTURE, supra note 42 , at 81 ("The hand of man reaches out to the heavens, nothing is impossible anymore."); Deus Caritas Est, supra note 31, at II 30(a) ("Despite the great advances made in science and technology, each day we see how much suffering there is in the world on account of different types of poverty, both material and spiritual.").

${ }^{67}$ Pilgrim Fellowship of Fatth, supra note 28, at 289. 
critical danger. In a very real sense, technology can pose a threat to the $21^{\text {st }}$ century environment in a way that it did not do before. In the past, environmental harm was essentially localized. While the potential for severe environmental harm existed, that harm would, most often, be confined to a local area. Now, however, human activity may have the ability to pose a threat that may reach a global scale. Pope Benedict XVI has written that

[e]cological disaster could serve as a warning to us, that we may see where science is no longer at the service of truth, but is destructive both of the world and of man. The ability to hear such warnings, the will to let oneself be purified by the truth, is essential. ${ }^{68}$

These repeated warnings about technology speak to the need to use wisdom and prudence to ensure that misuse or overuse of technology does not harm the environment.

Equally dangerous as this physical threat, however, is the indirect attitudinal and moral danger that new technology poses to the environment. Pope Benedict XVI repeatedly expresses his consistent concern that the increase in technology and scientific development has created a sentiment among many that humanity is now entirely in control of creation. ${ }^{69} \mathrm{He}$ laments that

Previously human beings could only transform particular things in nature; nature as such was not the object but rather the presupposition of their activity. Now, however, it itself has been delivered over to them in toto. Yet, as a result, they suddenly see themselves imperiled as never before. The reason for this lies in the attitude that views creation only as the product of chance and necessity. Thus it has no law, no direction of its own. The inner rhythm that we infer from the

\footnotetext{
68 Truth and Tolerance, supra note 28, at 159.

${ }^{69}$ See, e.g., Principles of CATHolic Theology, supra note 47, at 93 ("This liberation of man from the soul of the earth, from the foreordination to which he owes his existence, is most evident in the notion of perfect domination over life and death."); Joseph Cardinal Ratzinger, Church, Ecumenism, and Politics: New Essays in EcclesiolOGY 184 (1988) (hereinafter "CHURCH, ECUMENISM, AND Politics") (noting that modern man enjoys "emancipation from the compulsion of nature."); SPIRITUAL VISION, supra note 45, at 142 ("Biological manipulation is striving to uncouple man from nature."); Pope Benedict XVI, Urbi et Orbi Message of His Holiness Benedict XVI, Rome, December 25, 2006 ("Is a 'Savior' still needed by a humanity which has reached the moon and Mars and is prepared to conquer the universe; for a humanity which knows no limits in its pursuit of nature's secrets and which has succeeded even in deciphering the marvelous codes of the human genome?"); Pope Benedict XVI, General Audience, Rome, January 3, 2007 (condemning "scientific atheism"); and Pope Benedict XVI, Address of His Holiness Benedict XVI to the Roman Curia Offering Them His Christmas Greetings, December 22, 2006 ("[T] he power the human being holds in his hands which science has increased, is increasingly becoming a danger that threatens the human being himself and the world. Reason totally oriented to taking the world in hand, no longer accepts limits.").
} 
scriptural account-the rhythm of worship, which is the rhythm of the history of God's love for humankind-is stilled. Today we can see without any difficulty the horrible consequences of this attitude. ${ }^{70}$

This view excludes God from the world, ${ }^{71}$ and can lead to environmental destruction as well as other ills to the human family that result from such arrogance, ${ }^{72}$ when technology breeds a "culture in which scientific

\footnotetext{
${ }^{70}$ In the BEGINNING, supra note 1 , at 37.

${ }^{71}$ See PILGRIM Fellowship of FatTh, supra note 28, at 290 ("There is today a materialistic version of the theory of evolution that presents itself as being the last word in science and lays claim to have made the creative spirit superfluous through its hypothesis, indeed to have excluded it definitively."); Joseph Cardinal Ratzinger, The Ratzinger Report: AN Exclusive Interview on The State of the Church 66 (with Vittorio MEssoRI) (1985) (hereinafter "RATZINGER REPORT") ("Faith, indeed, is threatened with destruction every time science sets itself up as an absolute."); Pope Benedict XVI, Homily of His Holiness Benedict XVI, Cappella Papale, December 8, 2005 ("If we live in opposition to love and against the truth-in opposition to God-then we destroy one another and destroy the world. Then we do not find life but an act in the interests of death."); Pope Benedict XVI, Address of His Holiness Benedict XVI at the Presentation of the Letters Accrediting New Ambassadors to the Holy See, Rome, June 16, 2005 (hereinafter "Address to New Ambassadors") ("[O]ur world is facing numerous challenges that it must successfully confront so that the human person may always triumph over technology."); FAITH AND THE FutURe, supra note 42, at 5 (lamenting that "a great gulf is developing between the world of faith and the world of science."); THEOLOGICAL HIGHLIGHTS OF VA'TICAN II, supra note 62, at 161-162 ("[T]echnological application of scientific insights has given man an entirely new kind of power over the world. This in turn implies a new orientation toward human existence, based on the opportunity to make things functional in the service of man.... He no longer approaches the world from the viewpoint of contemplation and wonder, but as one who manages, weighs, and acts."); Pope Benedict XVI, Address of His Holiness Benedict XVI to the Participants at the $20^{\text {th }}$ International Conference Organized by the Pontifical Council for Health Pastoral Care on the Theme of the Human Genome, Rome, November 19, 2005:
}

The contemporary world is marked by the process of secularization. Through complex cultural and social events, it has not only claimed a just autonomy for science and the organization of society but has all too often also obliterated the link between temporal realities and their creator, even to the point of neglecting to safeguard the transcendent dignity of human beings and respect for human life itself.

${ }^{72}$ See Theological Highlights of Vatican II, supra note 62 , at 158:

[W] must also recognize that suspicion is not completely allayed until we have freely and without illusion examined the negative and retrogressive aspects of progress and have honestly measured the difference between technological and human progress. But, the crucial question goes even deeper... What is the relationship between technological progress and Christian hope?

See also Pope Benedict XVI, Address of His Holiness Benedict XVI to H.E. Mr. Ivan Guillermo Rincon Urdaneta, Ambassador of the Bolivian Republic of Venezuela to the Holy See, Rome, August 25, 2005 [hereinafter "Venezuela Address"] "[T]he social situation does not improve with the application of technological means alone; it is also 
and technical self-determination is becoming ever more total." ${ }^{.73}$ In the view of Pope Benedict XVI, the humility that comes from understanding that the Creator rules creation is in danger from the growing perception that humanity is now in complete control. Thus, creation itself is imperiled. He has written:

We have learned all the things that can be done with nature. The significance of this knowledge and of the ability that has been attained in this way should not be belittled. The only thing is that, if we grant validity to this way of thinking alone, the throne of domination over nature on which we have placed ourselves will have been built on nothing: it must collapse and bring us and the world down in its fall. To be able to do and make is one thing, to be able to be is another: being able to do and make is of no use if we do not know what it is for, if we no longer ask who we are and what the truth of things is. ${ }^{74}$

Rather than pursue this arrogant view, he advocates a more modest view of humble thanksgiving. "Thanksgiving for creation," he says, "could then become a reflection on creation, a reflection on behavior appropriate to our being part of creation. This would be acting according to the Spirit turning away from the ... materialism that abuses and betrays the world." 75 In his very first Christmas greeting to the Roman Curia, Pope Benedict XVI offered an "invitation not to see the world that surrounds us solely as raw material with which we can do something, but to try to discover in it 'the Creator's handwriting,' the creative reason and the love from which the world was born and of which the universe speaks to us, if we pay attention, if our inner senses awaken and acquire perception of the deepest dimensions of reality." 76

necessary to pay special attention to promoting values, with respect for the ethical dimension proper to the person, the family and social life.") and FAITH \& THE FUTURE, supra note 42, at 71 ("Positivism, exact scientific method, is unbelievably useful and absolutely necessary for mastery of the problems of ever-developing humanity. But positivism as a philosophy of life is intolerable and the end of humanity.").

${ }^{73}$ PRinciples of CATHOLIC Theology, supra note 47 , at 15.

${ }^{74}$ To Look on CHRIST, supra note 28, at 22. See also Synod Opening Homily, supra note 53 ("We men and women, to whom creation is, as it were, entrusted for its management, has usurped it. We ourselves want to dominate it in the first person and by ourselves. We want unlimited possession of the world and of our own lives."); THEOLOGICAL Highligits of VATICAN II, supra note 62, at 164 ("Technology does not decide whether progress works to salvation or destruction; this decision comes from another source. Thus a perspective opens up which looks toward the only redemptive force-the saving power of love."); and VALUES IN A TIME OF UPHEAVAL supra note 61, at 26 ("[S]cience ... is subject to moral criteria and ... its true nature is lost wherever the only criterion to which it adheres is power or commerce-or even merely success-instead of human dignity.").

75 Seek That Which is ABove, supra note 27, at 81.

${ }^{76}$ Christmas Address to the Curia, supra note 27. He proposed this invitation as an alternative to "radical liberalism and the natural sciences, which ... claimed to em- 
This concern about the ecological impact of technology is a concern that Pope Benedict XVI has shared in his ecumenical dialogue. Pope Benedict XVI and Patriarch Bartholomew I issued a joint statement in which they both lamented the ways in which the arrogant use of technology can lead to environmental harm. They wrote:

[I]n the face of the grave threats to the natural environment, we want to express our concern at the negative consequences for humanity and for the whole of creation which can result from economic and technological progress that does not know its limits. ... [W] consider it one of our duties to encourage and to support all efforts made to protect God's creation, and to bequeath to future generations a world in which they will be able to live. ${ }^{77}$

Thus, the third element of Pope Benedict XVI's ecological thoughtand one about which he has already preached as Pope-is to exercise caution when contemplating the harms that advancing technology may pose to the physical environment and, in so doing, embrace a correct understanding of humanity's place vis-à-vis Creator and creation.

\section{Humanity Must Be Respected in Proposed Ecological Solutions}

The fourth theme of Pope Benedict XVI's ecological thinking is one that places him in very close alliance with his predecessor, and simultaneously may put him at odds with many secular environmentalists. Pope Benedict XVI acknowledges that humanity is capable of and, indeed, engages in, destructive behavior vis a vis the environment. ${ }^{78}$ Indeed, he laments that " $[t]$ he problems of our time are attributable

brace with their knowledge the whole of reality to its limit, stubbornly proposing to make the 'hypothesis of God' superfluous." Id.

${ }^{77}$ Pope Benedict XVI and Patriarch Bartholomew I, Common Declaration by His Holiness Pope Benedict XVI and Patriarch Bartholomew I, November 30, 2006. These ecumenical collaborations are discussed more fully in John L. Allen, Jr., Pope and Patriarch Both Speak Out on Environment, National Catholic Reporter, Jan. 12, 2007 at 14.

${ }^{78}$ See God And The World, supra note 30 , at 51.

The Christian faith holds that the creation has been damaged. Human existence is no longer what was produced at the hands of the Creator. It is burdened with another element that produces, besides the innate tendency toward God, the opposite tendency away from God. In this way, man is torn between the original impulse of creation and his own historical inheritance.

See also In THE BEGINNING, supra note 1, at 81 ("God's creation and 'nature' are having to defend themselves against the limitless pretensions of human beings as creators. Human beings want to understand the discovered world only as material for their own creativity. Suddenly, humans' own creations no longer appear simply as a hope, possibly humankind's only one, but rather as a threat: humans are sawing off the branch on 
in good measure to the fact that we have regarded the world as mere matter, and matter as mere raw material for the production line. We need not be surprised that a world that is nothing but matter is becoming uninhabitable." ${ }^{79} \mathrm{He}$ does not underestimate the human capacity for wrongdoing and has decried "[t]he human threat to all living things, which is being spoken of everywhere these days." ${ }^{80} \mathrm{He}$ soberly warns that "the ominous effects of our own activities-the very elements by which we live-are threatened with destruction by the poisonous breath of our techniques; the energies upon which we depend seem, by their by-products, to be turning into the forces of our eventual annihilation." 81

Simultaneously, however, he forcefully rejects the view that humanity is to be vilified and attacked as a prerequisite for environmental progress. He expresses regret that "[t]he image of man that dominates in modern literature, in visual arts, cinema, and theater is primarily a gloomy image." ${ }^{\prime 2} \mathrm{He}$ also criticized the fact that:

... [T] here is devised a new and no less ruinous view-an attitude that looks upon the human being as a disturber of the peace, as the one who wrecks everything, as the real parasite and disease of nature. Human beings no longer have any use for themselves; they would prefer to put themselves out of the way so that nature might be well again. But this is not how to bring healing to the world, for we go against the Creator when we no longer want to exist as the human beings that he wanted to exist. It is not thus that we heal nature, but rather thus that we destroy both ourselves and creation by removing from it the hope that lies in it and the greatness to which it is called. ${ }^{83}$

The view of humanity that Pope Benedict XVI proposes may be seen by many as unrealistic in its praise of the potential for good that is possessed by mankind. He writes, in a discussion of the patron saint of ecology:

which they sit. The real creation seems like a refuge, to which they look back and which they seek anew.").

79 Seek That Which is Above, supra note 27, at 80.

${ }^{80}$ In The Beginning, supra note 1 , at ix.

${ }^{81}$ FAITH AND THE FUTURE, supra note 42 , at 85.

${ }^{82}$ A Turning Point For Europe, supra note 55, at 15. See also Seeking God's Face, supra note 48 , at 43 ("We are living in a time when man is denounced as a naked ape or as a particularly treacherous rat and when he is regarded as the real mischief maker who is destroying nature. Man is disgusted with mankind and fears his fellow men. His hatred of the humanity in himself and in others is clearly growing."); and IN THE BEGINNING, supra note 1, at 93 ("Reaction and resentment against technology ... has long since become a resentment against humans, who are seen as the disease of nature. This being that emerges out of nature's exact objectivity and straightforwardness is responsible for disturbing the beautiful balance of nature.").

${ }^{83}$ In The Beginning, supra note 1 , at 38. 
[W] are interested in Francis of Assisi especially as a lover of animals and as the patron saint of those who are concerned with the conservation of our natural environment. In our greed, we are stripping the world more and more of its natural resources, and our concern to protect nature is certainly both good and necessary.

Many of those most concerned in this work, however, are seriously mistaken in the emphasis they place on man in this question of conservation. They see man as the only real mischief-maker who is exclusively responsible for upsetting the peaceful balance of nature. Much of what they say points to a scornful attitude toward man and a desire to limit his spirit.

Francis' attitude toward man and nature was quite different. The seraphic idea of man, in whom the creature learns to soar and to sing, to transcend itself and give of itself, was fulfilled in him. Whenever that happens, the deepest longing of the creature is expressed and its hidden sadness is transmuted into confidence and joy. Nature will not be saved by denying the Spirit. Man will only learn to respect nature if the Spirit of God is set free in him in a gesture of pure love. ${ }^{84}$

Rather than pursue a negative view of humanity in the ecological picture, Pope Benedict XVI's view is that humanity is fundamentally good, ${ }^{85}$ and has a unique role in protecting creation. With that, however, comes a heightened moral responsibility. ${ }^{86} \mathrm{He}$ remarks that:

${ }^{84}$ SEEKING GoD's FACE, supra note 48, at 57-58. For a similar account of the lessons to be learned from St. Francis about the intertwining obligations to respect humanity and creation, see Seeк Thaт Which Is Aвove, supra note 27, at 131-32:

[T] his story [of St. Francis] contains none of the bitterness against human beings (for their alleged interference in nature), such as one detects in so many conservationist manifestos today. When man himself is out of joint and can no longer affirm himself, nature cannot flourish. On the contrary: man must first be in harmony with creation and it with him. And this is only possible if he is in harmony with the Creator who designed both nature and us. Respect for man and respect for nature go together, but ultimately both can only flourish and find their true measure if, in man and nature, we respect the Creator and his creation. The two only harmonize in relationship with the Creator. We shall assuredly never find the lost equilibrium if we refuse to press forward and discover this relationship.

For a related discussion of the connections between human harmony and creation, see Pope Benedict XVI, Angelus, Rome, June 5, 2005 ("I hope that sport practised in a healthy and armonious way at all levels will encourage brotherhood and solidarity between people as well as respect and an appreciation of the natural environment.")

${ }^{85}$ See IN THE BEGINNING, supra note 1, at 43 ("The human being has not been formed from negative forces, but has been fashioned from God's good earth."); Id. at 95 ("Christian love presupposes faith in the Creator. It must include acceptance of myself as his creature and love of the Creator's creation in me."); Sacramentum Caritatis, supra note 26, at II8 ("At creation itself, man was called to have some share in God's breath of life."); and Pope Benedict XVI, Homily of His Holiness Benedict XVI on His Pastoral Visit to the Roman Parish of Dio Padre Misericordioso, Rome, March 26, 2006 ("[W]e have all been created and redeemed by a God who sacrificed his only Son out of love.").

${ }^{86}$ See GOD AND THE WORLD, supra note 30, at 119 ("I think that the greatness of man is more obvious to us nowadays than ever before-and, of course, also the danger of 
Man is indeed a kind of bridge. He is the point at which the material world and the spiritual world meet and mingle and thus occupies a special place in the matrix of the created order. . . . That gives him a quite special function: that is to say, sharing the responsibility for the unity of creation, incarnating spirit in himself and, conversely, lifting material being up to God-and, thereby, all in all, making a contribution to the great symphony of creation. ${ }^{87}$

Others have written far more extensively than Pope Benedict XVI on the theme of stewardship as a proper role for mankind vis a vis creation. ${ }^{88}$ Indeed, this is a theme that is not yet extensively developed in his writing. ${ }^{89}$ Instead, his theology speaks of a special role for humanity based on mankind's unique status and close relationship both to God and to the natural world. Pope Benedict XVI has preached that "in the

falling from greatness. For the greater a creature is, the greater the danger it runs."); IN THE BEGINNING, supra note 1, at 48 ("[T] o the question as to what distinguishes the human being from an animal ... the answer has to be that they are the beings that God made capable of thinking and praying. They are most profoundly themselves when they discover their relation to their Creator. ... [H] uman persons are beings of word and of love, beings moving toward Another, oriented to giving themselves to the Other, and only truly receiving themselves back in real self-giving."); RATZINGER REPORT, supra note 71, at 98 ("To respect biology is to respect God himself, hence to safeguard his creatures."); Pope Benedict XVI, Angelus, Rome, December 24, 2006 ("[W]e are precious and unique in the eyes of the Creator."); Venezuela Address, supra note 72:

Venezuela has been wonderfully endowed by the Creator with natural resources. This brings with it the responsibility to cultivate and care for the gifts received, so that all its inhabitants may have the possibility of living with the dignity that befits human beings. In this task, no one may feel exempt from active collaboration, especially in cases of poverty or social marginalization.

87 GOD AND THE WORLD, supra note 30 , at 89.

${ }^{88}$ Pope Benedict XVI himself recognized this lengthy tradition in his very first Advent Angelus address when he quoted the stewardship theme as articulated in the landmark Vatican II document, Gaudium et Spes. In his remarks, Pope Benedict XVI says, "I am referring in particular to [that section of Gaudium et Spes in which] . . . we read: 'We are taught that God is preparing a new dwelling and a new earth. . . . Far from diminishing our concern to develop this earth, the expectancy of a new earth should spur us on, for it is here that the body of a new human family grows." Pope Benedict XVI, Angelus, St. Peter's Square, November 27, 2005.

${ }^{89}$ However, the stewardship theme is being mentioned increasingly more often in some of Pope Benedict's more recent statements. See, e.g., Pope Benedict XVI, Homily of His Holiness Benedict XVI, Rome, February 5, 2006 ("Man is not the master of life; rather, he is its custodian and steward, and under God's primacy, this priority of administrating and preserving human life, created by God, comes automatically into being. The truth that man is the custodian and steward of life is a clearly defined point of natural law, fully illumined by biblical revelation."); and Pope Benedict XVI, Homily of His Holiness Benedict XVI at the Eucharistic Celebration for all Workers on the Feast of Saint Joseph, Rome, March 19, 2006 ("When the Creator shaped man in his image and likeness, he asked him to till the land."). 
human being, heaven and earth touch one another. In the human being God enters into his creation; the human being is directly related to God."90

He remarks that "the human person ... is the only one of all the creatures on this earth who can establish a free and conscious relationship with his or her creator." 91 Thus, any environmental proposals or ideologies that would undermine the central dignity of the human would run counter to Pope Benedict XVI's vision. ${ }^{92}$ Thus, those envi-

${ }^{90}$ SPIRITUAL VISION, supra note 45, at 104. See also God AND THE WoRLD, supra note 30 , at 77 ("God intended us to live in inner harmony with creation, as well as in the security represented by life with Him.... [T] hese two conditions, being guardian of creation and being in direct contact with God, so as to carry on the work of creation with him ... are suggested."); IN THE BEGINNING, supra note 1, at 38 ("[W]e can be really 'creative' only if we are in harmony with the creator of the universe. We can really serve the earth only if we accept it under the aegis of God's Word."); and Id. at 39 ("[O]nly if we trust the Creator shall we find ourselves on the way to saving the world of human beings and of things."). See also Pope Benedict XVI, Address of His Holiness Benedict XVI to the Pontifical Academy of Sciences and the Pontifical Academy of Social Sciences, Rome, November 21, 2005:

Humans are part of nature and, yet, as free subjects who have moral and spiritual values, they transcend nature. This anthropological reality is an integral part of Christian thought and responds directly to the attempts to abolish the boundary between human sciences and natural sciences, often proposed in contemporary society. . . . God created man and woman in his own image and likeness and granted them a superior dignity and a shared mission towards the whole of creation.

${ }^{91}$ Pope Benedict XVI, Angelus, St. Peter's Square, December 4, 2005. This distinction between humanity and other creatures is described again, in a different context, when Pope Benedict explains, "The biblical account of creation speaks of the solitude of Adam. . . . Of all other creatures, not one is capable of being the helper that man needs, even though he has assigned a name to all the wild beasts and birds and thus made them fully a part of his life." Deus Caritas Est, supra note 31, Il 11.

${ }^{92}$ See Pope Benedict XVI, Meeting with the Diplomatic Corps to the Republic of Turkey, Address of the Holy Father, Ankara, November 28, 2006:

The voice of the Church on the diplomatic scene is always characterized by the Gospel commitment to serve the cause of humanity, and I would be failing in this fundamental obligation if I did not remind you of the need always to place human dignity at the very heart of our concerns. The world is experiencing an extraordinary development of science and technology, with almost immediate consequences for medicine, agriculture and food production, but also for the communication of knowledge; this process must not lack direction or a human point of reference, when it relates to birth, education, manner of life or work, of old age, or death. It is necessary to re-position modern progress within the continuity of our human history and thus to guide it according to the plan written into our nature for the growth of humanity-a plan expressed by the words of the book of Genesis as follows: "Be fruitful, multiply, fill the earth and subdue it."

Pope Benedict XVI echoed a similar theme in his remarks concerning the challenges facing Latin America in which he lamented "increasing poverty and ecological deterio- 
ronmental initiatives that focus on population control as a remedy for environmental ills would be condemned as they do not respect the central dignity of the human person. Likewise, those plans that do not offer sufficient recognition of the human need to farm, build, earn a livelihood, and use natural resources to support a family would be subject to critical review. This is particularly true in the poorer regions of the world, where immediate human needs are both urgent and complex. ${ }^{93}$

Pope Benedict XVI highlighted the centrality of the human person in a recent statement to the United Nations Food and Agriculture Organization, when he commented that "[t]rue progress is that alone which integrally safeguards the dignity of the human being and which enables each people to share its own spiritual and material resources for the benefit of all."94

Soon after the start of Pope Benedict XVI's papacy, the first-ever Working Group on Water and the Environment was sponsored by the Pontifical Academy of Sciences. In addressing the goal of the workshop, it was stated that, when it comes to problems with the quality and quantity of clean water:

ration, especially in the large cities." Pope Benedict XVI, Address of His Holiness Benedict XVI to the Participants in the Plenary Assembly of the Pontifical Commission for Latin America, January 20, 2007.

${ }^{93}$ For a fuller discussion of this complex problem, in the context of impoverished rural areas see Pope Benedict XVI, Message of His Holiness Benedict XVI to the Director General of the Food and Agriculture Organization for the Celebration of World Food Day, October 16, 2006. Pope Benedict XVI warned that, "[n]ot enough energy is given to the needs of agriculture, and this both upsets the natural order of creation and compromises respect for human dignity." He goes on to lament:

Very often, international action to combat hunger ignores the human factor, and priority is given instead to technical and socio-economic aspects. Local communities need to be involved in choices and decisions concerning land use, since farmland is being diverted increasingly to other purposes, often with damaging effects on the environment and the long-term viability of the land.

The order of creation demands that priority be given to those human activities that do not cause irreversible damage to nature, but which instead are woven into the social, cultural, and religious fabric of the different communities. In this way, a sober balance is achieved between consumption and the sustainability of resources.

Id.

${ }^{94}$ Pope Benedict XVI, Address of His Holiness Benedict XVI to the Participants in the Thirty-Third Conference of the United Nations Food and Agriculture Organization, November 24, 2005 [hereinafter "Food and Agriculture Organization Address."]. See also id. ("Humanity is presently experiencing a worrisome paradox: side by side with ever new and positive advances in the areas of economy, science and technology, we are witnessing a continuing increase of poverty."). 
[W]e can say that the problem has two main facets: the first belongs especially to the natural sciences (study the great basins, conserve them and develop them in a sustainable way with relation to the rest of the environment); the second facet pertains more to the social sciences (fair distribution of water). ${ }^{95}$

Access to water was again highlighted as a concern of the Holy See as it participated in the Fourth World Water Forum in Mexico City in March, 2006. Although the contribution to the Forum was prepared by the Pontifical Council for Justice and Peace, and not written by Pope Benedict XVI himself, the themes it articulates reiterate themes dear to the heart of Pope Benedict XVI. First, it praises the gift of water from the Creator, and expresses the obligation to use this gift, as well as other gifts of creation, for the common good:

\begin{abstract}
Water is a natural resource vital for the survival of humanity and all species on earth. As a good of creation, water is destined for all human beings and their communities. God intended the earth and all it contains for the use of all, so that all created things would be shared, fairly, by humankind under the guidance of justice tempered by charity. ... Water is a universal common good, a common good of the entire human family.... This natural resource must be equitably at the disposal of the entire human family. ${ }^{96}$
\end{abstract}

The document also echoes Pope Benedict XVI's concern for placing human rights at the center of ecological discussions. It argues, "[d]efining access to safe water as a human right is an important step in making this access a reality in the lives of many people living in poverty. A rights based approach places the human being at the center of devel-

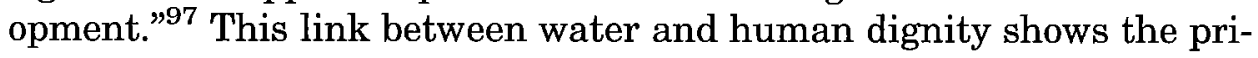

${ }^{95}$ Pontifical Academy of Sciences, Working Group on Water and the Environment, Conference Brochure, November 12-14, 2005 at 3 (on file with author). For additional background on this Working Group, see, e.g., John Thavis, Scientists, Ethicists Say Water is Essential Resource of the Future, Catholic News Service, November 15, 2005 (www.catholicnews.com/data/stories /cns/0506530.html); Angelina Sciolla, Vatican, Scientists Consider World's Water Rights, Science \& Theology News, January 18, 2006 (www.stnews.org/News-2577.html). See also Pope Benedict XVI, Homily of the Holy Father, Istanbul, December 1, 2006 (decrying "a world where men are so loath to share the earth's goods and there is a dramatic shortage of water, the good so precious for the life of the body.").

${ }^{96}$ Pontifical Council for Justice and Peace, Water, An Essential Element for Life: A Contribution of the Holy See to the Fourth World Water Forum, Mexico City, March 16-22, 2006. [hereinafter "An Essential Element of Life."]

${ }^{97} I d$. at 96 . In addition, this document explores more fully the link between access to clean water and the existence--or lack, thereof-of world peace. It warns, "[c]onflicts have already occurred for control over water resources, and others may come center stage the more water scarcity manifests its consequences on the lives of human beings and their communities." Id. See also id. ("The vital importance of water to humanity 
ority that this issue will be given, since it does not place humans in conflict with the natural environment but, instead, sees the good of one intertwined with the good of the other. ${ }^{98}$

Pope Benedict XVI is likely to encourage environmentalists to focus on the connection between human need and the natural world, rather than the real or perceived opposition between them. Water is but one timely illustration of these issues likely to gain attention because it marries both human need and ecological concerns. Thus, a very clear fourth element of Pope Benedict XVI's ecological thought is ensuring that the proper role of humanity is respected in all decison making.

\section{A View to the Future}

"We can win the future only if we do not lose creation." 99

In many respects, it is difficult to predict the exact role that Pope Benedict XVI will play in the further development of Catholic social teaching in the area of environmental ethics. As the previous discussion illustrates, however, he has already devoted considerable thought to this question. Unlike his predecessor who welcomed-and, at times, seemed to relish - a role on the world stage, Pope Benedict XVI appears to be a bit more ambivalent about the intervention of the Church in detailed policy-making. To illustrate this tension, he has written, "the Church must make claims and demands on public law, and cannot

means also that it is a strategic factor for the establishment and maintenance of peace in the world."); Id. ("To foster peace and an appropriate level of security in the current world situation governments and international organizations will inevitably have to increase efforts to ensure that every person has access to safe water.").

${ }^{98}$ See id. ("[C]ommon agreement exists that the survival of humanity and all species on earth depends to a great degree on the fate of water."); Id ("Water is much more than just a basic human need. It is an essential, irreplaceable element to ensuring the continuance of life. Water is extrinsically linked to fundamental human rights, such as the right to life, to food, and to health."); Id. ("The human being is the center of the concern expressed in this updated document. Solutions for access to safe water and sanitation should express a preferential love and consideration for the poor.... The water issue is truly a right to life issue."). A similar theme was developed in an ecumenical reflection as well. See Common Declaration Signed by Pope Benedict XVI and H.B. Christolodoulos, Archbishop of Athens and All Greece, December 14, 2006:

[I]t is . . . important not to exploit or abuse creation, which is the work of God. In this regard, we appeal to social leaders and to all people of good will to engage in a reasonable and respectful stewardship of creation, so that it may be correctly administered in a spirit of solidarity, especially for the sake of the peoples afflicted by famine, so as to bequeath to future generations a world that is truly inhabitable for everyone.

99 In The Beginning, supra note 1, at 100. 
simply retreat into the private sphere.... [I]t must also take care on the other hand that Church and State remain separated." ${ }^{100}$ This tension between the roles of public authorities and private individuals is likely to influence the approach Pope Benedict XVI takes toward environmental teachings.

Pope Benedict XVI's writings underscore the fact that environmental protection includes a significant component of personal moral responsibility, ${ }^{101}$ criticizing the way in which "we do not lay our hands on the earth, hands that so often exploit and violate it."102 A critical component of this moral obligation, as articulated by Pope Benedict XVI, is the need to turn away from destructive and careless consumerism. As he has written,

Nature resists unbridled consumption, and this is why the state of the environment has prompted new reflections on the direction that nature itself indicates. The lordship over nature of which the biblical creation narrative speaks does not mean a violent exploitation of nature but, rather an understanding of nature's inherent possibilities. This suggests a caution in the way in which we serve nature and nature serves us. ${ }^{103}$

Unlike his predecessor, however, Pope Benedict XVI has not yet written extensively about the moral responsibility that may exist for governmental entities, either national or international. Much could be said about the moral responsibility of wealthy nations to poor ones, or of international organizations to the nations they serve. Pope Benedict XVI has hinted at this when he wrote that "[t]he earth, in fact, can produce enough to nourish all its inhabitants on the condition that the rich countries do not keep for themselves what belongs to all." ${ }^{104} \mathrm{He}$ has

\footnotetext{
100 SPIRITUAL VISION, supra note 45, at 131.

${ }^{101}$ See, e.g., PILGRIM Fellowship, supra note 28, at 296-97 ("[B]ecause God is love, that is why the Commandments, in which his will is made known, are the essential variations of the single theme of love. They are the practical rules of love for God, for my neighbor, for creation, for ourselves."); Sacramentum Caritatis, supra note 26, at II92 ("The justified concern about threats to the environment present in so many part of the world is reinforced by Christian hope, which commits us to working responsibly for the protection of creation."); and Pope Benedict XVI, Message of His Holiness Benedict XVI for Lent 2006, September 29, 2005 ("Even in this era of global interdependence, it is clear that no economic, social or political project can replace that gift of self to another through which charity is expressed.").

102 The Feast of FaITH, supra note 26, at 135.

${ }^{103}$ Values in a Time of UPheAval, supra note 61, at 159.

${ }^{104}$ Pope Benedict XVI, Address of His Holiness Benedict XVI at the Presentation of the Letters Accrediting New Ambassadors to the Holy See, Rome, June 16, 2005. Pope Benedict XVI echoed a similar theme when he lamented:
} 
also begun to make several practical suggestions with regard to agricultural support. ${ }^{105}$

However, to date, this realm of detailed governmental policy is not where he has placed his emphasis. Instead, thus far, his writings are largely devoted to the moral obligations of individuals to respect creation. ${ }^{106} \mathrm{He}$ has said, for example, in a slightly different context, "It is easier to demonstrate for the rights and freedoms of one's own group than to practice in daily living the discipline of freedom and the patience of love for those who suffer, or, indeed, to bind oneself to such service for the whole of one's life, with the concomitant renunciation of a great part of one's own individual freedoms." ${ }^{107} \mathrm{He}$ has identified the moral problem to be one of misplaced priorities and values, saying "we

The traditional biblical fullness of food and years, considered a sign of divine blessing, is now countered by an intolerable satiety composed of an excessive load of humiliations. And we know today that many nations, many individuals, are truly burdened with derision, with the contempt of the rich and the disdain of the proud.

Pope Benedict XVI, General Audience, Rome, June 15, 2005. See also God AND ThE WoRLD, supra note 30, at 430 ("When I think... that in Europe they pay farmers subsidies to kill off their livestock, to destroy grain crops, grapes, all kinds of fruit, because we supposedly cannot control overproduction, then it seems to me that these knowledgeable managers ought still to reflect on how, instead of destroying these gifts of creation, we could make good use of them all."); and Pope Benedict XVI, Urbi et Orbi Message of His Holiness Pope Benedict XVI, Rome, December 25, 2006 ("People continue to die of hunger and thirst, disease and poverty, in this age of plenty and of unbridled enthusiasm.").

${ }^{105}$ See, e.g., Food and Agriculture Organization Address, supra note 94:

It must not be forgotten that the vulnerability of rural areas has significant repercussions on the subsistence of small farmers and their families if they are denied access to the market. A consistent course of action would call for recognizing the essential role of the rural family as a guardian of values and a natural agent of solidarity in relationships between the generations.

${ }^{106}$ Indeed, this is the view he has articulated with regard to individual obligations in the social realm more generally. In Deus Caritas Est, he said simply, "We contribute to a better world only by personally doing good now." Deus Caritas Est, supra note 31, at II 31(b). See also Amazon River Letter, supra note 25 (discussing the personal "commitments of each one to safeguard the habitat that the Creator has made available to the human being, in whom he has impressed his own image.").

${ }^{107}$ A Turning Ponnt For Europe, supra note 55, at 26. See also id. at 73:

The gift of the Law is the real establishment of liberation-and of a Law that is truly justice, namely right order in relationship to one another, in relationship to creation, and in relationship to the Creator. Man's freedom can exist only in the correct mutual allocation of these freedoms.

A similar theme was echoed in Gospel, Catechesis, Catechism, supra note 27, at 12:

While it is certainly neither possible nor desirable to live by prohibitions and accusations, the question about our duty as human beings, about the land of life required for the rectitude of our own being and the being of the world, is the essential question of every age. 
are embarrassed by the way the human spirit has misused matter and creation. But such misuse comes precisely through things being given priority over the person."108

Clearly, Pope Benedict XVI acknowledges that there is a role for the Church in the affairs of the world and in bettering the human condition by playing a part in the public square ${ }^{109}$ Indeed, in his first homily to the Synod of Bishops in October of 2005, he lamented that there is a modern perception that

God is in our way. Either he is reduced merely to a few devout words, or he is denied in everything and banned from public life so as to lose all meaning. The tolerance that admits God ... as a private opinion but refuses him the public domain, the reality of the world and of our lives is not tolerance but hypocrisy."110

${ }^{108}$ SEek That Which Is ABove, supra note 27, at 47. See also id. at 103 ("Today, by progress we generally mean the growth in the scope of technology and the increase in the gross national product. When we say progress, quite simply, we think of 'having' more."). See also 2006 World Youth Day Homily, supra note 45 (speaking of the need for "inner freedom from the greed for possession and the mania for power.").

${ }^{109}$ See, e.g., PILGRIM FEllowship, supra note 28, at 286 ("The Church is there to prevent the advance of hell on earth and to make the earth fit to live in through the light of God."); Id. at 287 ("The Church is there ... for mankind. She is there so that the world may become a sphere for God's presence, the sphere of the covenant between God and man."); Deus Caritas Est, supra note 31, at II 28(a) ("[T] he Church is duty-bound to offer, through the purification of reason and through ethical formation, her own specific contribution towards understanding the requirements of justice and achieving them politically. ... She cannot and must not replace the State. Yet at the same time she cannot and must not remain on the sidelines in the fight for justice. She has to play her part through rational argument and she has to reawaken the spiritual energy without which justice, which always demands sacrifice, cannot prevail and prosper."); Pope Benedict XVI, First Message of His Holiness Pope Benedict XVI at the End of the Eucharistic Concelebration with the Members of the College of Cardinals, Sistine Chapel, April 20, 2005 ("I . . . declare the willingness of all Catholics to cooperate for an authentic social development, respectful of the dignity of every human being."); MANY RELIGIONS, supra note 66, at 102 ("This refusal to turn religion into political moralism does not mean, of course, that education for peace, justice, and love for the Creator and creation are not part and parcel of the task of the Christian faith and of every religion."); and Pope Benedict XVI, Address of His Holiness Benedict XVI to the Diplomatic Corps Accredited to the Holy See, Rome, May 12, 2005:

[T] he Church never ceases to proclaim and defend the fundamental human rights, which unfortunately are still violated in various parts of the earth. She is working for recognition of the rights of every human person to life, food, a home, work, health-care assistance, the protection of the family and the promotion of social development, with respect for the dignity of men and women, created in the image of God.

${ }^{110}$ Synod Opening Homily, supra note 53. 
In addition, in his public prayers, he preached that "faith cannot be reduced to a private sentiment or indeed, be hidden when it is inconvenient; it also implies consistency and a witness even in the public arena for the sake of human beings, justice, and truth."111 He has also commented that solidarity between different nations is essential in setting policies that will be just internationally. ${ }^{112}$ This may suggest that, with time, the scope of Pope Benedict XVI's teaching on the role of the Church in the public square will expand, and his direct involvement in environmental debates will increase.

${ }^{111}$ Pope Benedict XVI, Angelus, St. Peter's Square, October 9, 2005. See also A Turning PoInt For Europe, supra note 55, at 56:

\begin{abstract}
Alongside this primary task of creating conviction, forming conscience, and fashioning community as a space for peace is the mission of the Church's office bearers, supported by the conviction of the faithful, to speak out publicly on questions of the moment and to be advocates of peace. In our own times, this has been taken up with much passion.
\end{abstract}

See also Joseph Cardinal Ratzinger, Called to Communion: Understanding the Church Today 101 (Trans: Adrian Walker) (1996):

[T]he bishop also has a responsibility for the public affairs of this world. The state is entitled to autonomy with respect to the Church, and the bishop must acknowledge that the state has its own reality and law. He avoids mixing faith and politics and serves the freedom of all by refusing to allow faith to be identified with a particular form of politics. The Gospel prescribes certain truths and values to politics, but it does not respond to concrete questions concerning particular political and economic issues.

112 SpIRITUAL VISION, supra note 45, at 128 ("Justice is no longer to be circumscribed by the boundaries of one country. North and South, rich nation and poor, form one world in which the fate of one group is not to be separated from that of another... Only when we keep in mind the justice of the whole world can we rightfully discern what justice means for us here and now."); 2006 World Youth Day Homily, supra note 45 (noting that Christ "comes in all cultures and all parts of the world, everywhere, in wretched huts and in poor rural areas as well as in the splendour of cathedrals. He is the same everywhere, the One, and thus all thou gathered with him in prayer and communion are also united in one body."); Pope Benedict XVI, Letter of His Holiness Benedict XVI to Cardinal Walter Kasper on the Occasion of the Second Conference on Peace and Tolerance, November 4, 2005:

It is the duty of every person of good will, and especially of every believer, to help build a peaceful society and to overcome the temptation towards aggressive and futile confrontation between different cultures and ethnic groups. Each of the world's peoples has a responsibility to make its own particular contribution to peace and harmony by placing its spiritual and cultural heritage and its ethical values at the service of the human family throughout the world. This goal can only be achieved if at the heart of the economic, social, and cultural development of each community is a proper respect for life and for the dignity of every human person. A healthy society always promotes respect for the inviolable and inalienable rights of all people.

See also Deus Caritas Est, supra note 31, at II 26 ("[T]he pursuit of justice must be a fundamental norm of the State and ... the aim of a just social order is to guarantee to each person, according to the principle of subsidiarity, his share of the community's goods."). 
Yet, Pope Benedict XVI is also wary of the Church's reach into those areas that are within the scope of lay expertise and prudential judgement, ${ }^{113}$ and he is cautious about an overly civic role for the Church. Indeed, he warns that "the Church does less, not more, for peace if she abandons her own sphere of faith, education, witness, counsel, prayer, and serving love, and changes into an organization for direct political action. ... Only when she respects her limits is she limitless."114 This is particularly true in the area of ecology, which involves not only lay political expertise but scientific knowledge as well. ${ }^{115}$ He has written, "Scripture would not wish to inform us about how the different species of plant life gradually appeared or how the sun and the moon and the stars were established. Its ultimate purpose would be to say one thing: God created the world." ${ }^{116}$ In his writings, he has warned:

Of course, our efforts on behalf of peace, justice, and the protection of creation are of the highest importance and religion should doubtlessly provide a vehicle for substantial action in this regard. But the religions have no a priori knowledge

${ }^{113}$ See A Turning Point For Europe, supra note 55, at 8:

It has become clear that one cannot plan and shape the future of mankind while prescinding from religion. This process gives comfort to faith, but faith will not fail to recognize at the same time the dangers inherent in it, for the temptation is obvious on all sides to take in religion as an instrument to serve political ideas.

${ }^{114} I d$. at 59. See also id. at 57 ("No social service of the state can replace Christian love in both its spontaneous and organized forms."); Id. at 157 ("Religion that has turned into politics makes excessive demands of politics and thereby becomes a source of the disintegration of man and society."); SPIRITUAL VISION, supra note 45, at 87 ("[T]he Kingdom of God is not a thing, a social or political structure, a Utopia. The Kingdom of God is God."); and Id. at 111 ("[T] he price of faith's union with political power is always paid in the end when faith is placed at the service of power and must bow to its criteria.").

${ }^{115}$ See, e.g., Theological Highlights OF Vatican II, supra note 62, at 162 ("[F]aith offers men directive guidance about their origin and destiny. But this does not mean that the Church has ready answers for all specific questions. Rather, the Church links its own search-a search for faith-with the search of mankind for solutions to these specific problems."). See also FAITH \& The FutURE, supra note 42, at 5:

The difficulty begins with the very first page of the Bible. The concept presented there of how the world came to be, is in direct contradiction of a what we know today about the origins of the universe; and even if the word has gotten around that these passages in the Bible are not meant to be a textbook of natural science, and so need not be taken as a literal description of how the universe came to be, still an uneasy feeling remains.

${ }^{116}$ In The Begrinning, supra note 1, at 5 . A similar point was made in JosEPH RATZinger, Introduction to Christianity 103 (1985) (J.R. Foster, Trans) ("For all the uncertainties about its origins, we can at any rate see that . . . God [is] the Lord of heaven and earth' . . . the Lord to whom the stars too belong, alongside whom the stars cannot exist as independent divine powers."). 
of ... how creation can best be protected and cultivated out of a sense of responsibility to the creator. All these things must be worked out rationally and on an individual basis. This always requires free debate between differing opinions and respect for different paths. Often, this pluralism of paths cannot be resolved, and if the wearying rational debate is cut short by a religiously motivated moralism that declares one path to be the only right one, religion is perverted into an ideological dictatorship, with a totalitarian passion that does not build peace by destroys it. Religion cannot be forced into the service of practical-political objectives; the latter would become an idol; man, making God the slave of his plans, would degrade both God and himself. ${ }^{117}$

This would suggest that Pope Benedict XVI may be more likely to direct his attention on ecological matters toward the moral education of individuals rather than governments. Whether or not this changes will be one important facet of his developing role on the world stage beyond Europe where, to date, most of his energy has been directed.

Nevertheless, on January 1, 2007, Pope Benedict XVI-like his predecessor, Pope John Paul II-used the occasion of the World Day of Peace message to offer an extensive reflection on ecology and obligations toward creation. This message, in an important way, marked his formal "debut" on the environmental scene, and demonstrates his ecological priorities as pope rather than as theologian. In his message, The Human Person, the Heart of Peace, ${ }^{118}$ Pope Benedict XVI devoted an entire section of his reflections to a discussion of what he termed "the 'ecology of peace."'119 In this discussion, he links care for the environment and care for humanity, and argues that disrespect for the environment often reflects precisely those human failings that threaten human peace. He reflected:

[H] umanity, if it truly desires peace, must be increasingly conscious of the links between natural ecology, or respect for nature, and human ecology. Experience shows that disregard for the environment always harms human coexistence, and vice versa. It becomes more and more evident that there is an inseparable link between peace with creation and peace among men. Both of these presuppose peace with God. ${ }^{120}$

\footnotetext{
${ }^{117}$ Many Religions, supra note 66, at 101-102. See also A Turning Point For Europe, supra note 55, at 57 ("What the Church has to remember is that, though the sources of law have been entrusted to her safekeeping, she does not have any specific answers to concrete political questions. She must not make herself out to be the sole possessor of political reason. She points out paths for reason to follow, and yet reason's own responsibilities remain."); and Deus Caritas Est, supra note 31, at II 29 ("The direct duty to work for a just ordering of society ... is proper to the lay faithful.").

${ }_{118}$ Pope Benedict XVI, Message of His Holiness Pope Benedict XVI for the Celebration of the World Day of Peace: Human Person, the Heart of Peace, January 1, 2007.

${ }^{119}$ Id., II 8 et seq.

${ }^{120}$ Id., II 8 (emphasis original).
} 
While prior papal writings have linked environmental degradation to threats to human development and economic well-being, the direct link to peace is a more recent argument. Pope Benedict XVI develops this link more fully as he articulates at least two specific ways in which threats to the natural environment can quickly lead to threats to human peace.

First, he warns, the fight over access to declining energy resources poses a growing threat to peace. He fears that the "increasingly serious problem of energy supplies" ${ }^{121}$ is one that may erupt in human conflict:

In recent years, new nations have entered enthusiastically into industrial production, thereby increasing their energy needs. This has led to an unprecedented race for available resources. Meanwhile, some parts of the planet remain backward and developmentally blocked, partly because of the rise in energy prices. What will happen to these peoples? What kind of development or non-development will be imposed on them by the scarcity of energy supplies? What injustices and conflicts will be provoked by the race for energy sources? And what will be the reaction of those who are excluded from this race? These are questions that show how respect for nature is closely linked to the need to establish, between individuals and between nations, relationships that are attentive to the dignity of the person and capable of satisfying his or her authentic needs. ${ }^{122}$

As he has done in the past, Pope Benedict XVI connected environmental affairs to human affairs and-in tension with some others in the environmental movement-suggests that a primary rationale for creation care is to avoid harm to humanity. Unlike his past writings, however, this specific identification of energy conflicts has a high degree of detail.

A second link between the natural environment and human peace is made when Pope Benedict XVI argues that the exploitation of the environment can lead to the degradation of humanity to a degree that may result in destruction and violence:

The destruction of the environment, its improper or selfish use, and the violent hoarding of the earth's resources cause grievances, conflicts and wars, precisely because they are the consequences of an inhumane concept of development. Indeed, if development were limited to the technical-economic aspects, obscuring the moral-religious dimension, it would not be an integral human development, but a one-sided distortion which would end up by unleashing man's destructive capacities. ${ }^{123}$

\footnotetext{
${ }^{121}$ Id., II 9.

${ }^{122}$ Id., II 9.

${ }^{123} \mathrm{Id}$.
} 
This is a more traditional critique of the link between environmental concern and human development. It is, however, a warning as to the concern that must be paid to the environmental harms that can lead to destruction to the human family.

In addition to these two specific discussions of the link between ecology and peace, Pope Benedict XVI also used the 2007 World Day of Peace statement to mention several other ways in which peace may be threatened by human indifference to the environment. He decried "inequality in access to essential goods like food, water. ...."124 and reiterated the familiar concern about the harm that nuclear weaponry could pose to creation. ${ }^{125}$

This was not the first time that Pope Benedict XVI has addressed the connection between the environment and peace. He has, in the past, commented on the potential for harm that is posed by warfare ${ }^{126}$ and nuclear weaponry. ${ }^{127} \mathrm{He}$ has previously warned that " $[\mathrm{t}]$ he first threat to peace . . . is the danger of the world war, the danger that the greater power blocks, into which the world is divided, would unleash against

${ }^{124}$ Id., II 6.
${ }^{125}$ Id., II $15:$

Another disturbing issue is the desire recently shown by some states to acquire nuclear weapons. This has heightened even more the widespread climate of uncertainty and fear of a possible atomic catastrophe. We are brought back in time to the profound anxieties of the "cold war" period.... Unfortunately, threatening clouds continue to gather on humanity's horizon.

126 See, e.g., FAITH AND THE FUTURE, supra note 42, at 85 ("[The] same technical skill which offers such opportunities to humanity offers also fresh opportunities to him who is anti-humane. There is no need to speak of the ultimate horrors of atomic weapons, and of biological and chemical warfare, although the store of terror they imply always lurks somewhere in our minds."); and VALUES IN A TIME OF UPHEAVAL, supra note 61, at 31 ("[T]he development of man's power to create and to destroy poses much more acutely than before the question of the legal and ethical controls on this power.").

${ }^{127}$ See A New SONG FOR THE LORD, supra note 33, at 37-38:

[T] here is a fear of the danger arising from humanity's arsenals of weapons that were again created to demonstrate the power of one state over another but now seem to be expanding further with compulsive dynamism so that the question of whether they can be controlled by governments has become urgent. Even with the hopes for disarmament growing anew, we still fear the automated nature of this machinery and the danger of its setting itself off.

See also Values in a Time of Upheaval, supra note 61, at 106 ("Since both terror and organized crime, which is spreading its net ever more widely and strongly, could conceivably get access to atomic and biological weapons, the peril that looms here is terrifying."); Pope Benedict XVI, Message of His Holiness Pope Benedict XVI for the Celebration of the World Day of Peace, January 1, 2006 ("In a nuclear war, there would be no victors, only victims."). 
each other those weapons of mass destruction that in all probability would bring about the destruction of the human race." ${ }^{\text {228 }}$ Pope Benedict XVI, of course, is not the first pontiff to be concerned about this issue, and he has praised his predecessors for their attention to this problem decades ago. ${ }^{129}$ Although he offers no particular solutions to this problem, it is noteworthy that he has identified this particular concern. Given the current state of world events, it is likely that the ecological damage resulting from conventional and modern warfare will become a very real issue during the papacy of Pope Benedict XVI. ${ }^{130}$ As he has warned:

Science is an immensely good thing precisely because it is a controlled form of rationality that is confirmed by experience. But there exist also pathological forms of science that deprive man of all honor, when scientific capabilities are put at the service of power. Science can also serve inhumanity! Here we may recall the weapons of mass destruction ... ${ }^{131}$

Naturally, pursuit of peace for its own sake is a worthy goal for myriad reasons unconnected to ecological well being. However, Pope Benedict XVI has also identified the lack of peace as an environmental threat as well.

This early emphasis on ecological concerns attracted the attention of commentators, ${ }^{132}$ and may signal that there may be future statements

${ }^{128}$ A Turning Pornt For Europe, supra note 55, at 42. See also Pope Benedict XVI, Homily of His Holiness Benedict XVI, Rome, January 1, 2007:

In the face of the threats to peace that are unfortunately ever present, the situations of injustice and violence that persist in various areas of the earth and the continuing armed conflicts often overlooked by the majority of public opinion, as well as the danger of terrorism that clouds the serenity of peoples.

${ }^{129}$ See Theological Highlights, supra note 62, at 102 ("[T] he frankness, the sober seriousness, the courage and objectivity of the bishops who spoke on such delicate questions as . . atomic warfare all had a healthy effect.").

${ }^{130}$ Interestingly, Pope Benedict recently addressed another, oft-neglected casualty of war and ecological catastrophe: the mental health consequences on victims. See Pope Benedict XVI, Address of His Holiness Benedict XVI to the Sick at the End of the Mass for the Sick, February 11, 2006 ("[N]atural disasters or, unfortunately, wars and armed conflicts are producing in people serious psychological traumas.").

131 Values in a Time of UPHEAVAL, supra note 61, at 26.

${ }^{132}$ See, e.g., Ian Fisher, Pope Benedict XVI Issues Annual Message for Peace, INTERnational Herald Tribune Europe, December 12, 2006 (available on line at www.iht .com/articles/2006/for peace, Pope 12/12/news/pope.php.) ("In an annual message for peace, Benedict strongly emphasized a theme rarely taken up in his nearly two years as pope: what he called the 'ecology of peace,' the idea that protecting the environment and finding alternate energy sources could also reduce conflict."); Gerard O'Connell, Pope Benedict XVI's Peace Day Message Identifies Triple Danger, CaTHolIC News SeR- 
from Pope Benedict XVI that follow up on the themes he raised in these remarks.

As Pope Benedict XVI's papacy continues, it will be interesting to observe the way in which he works with those who are in the forefront of environmental activism, but have often been at odds with the Church on theological matters. ${ }^{133}$ It remains to be seen how the traditional conflicts between these movements and with the Church's environmental intervention will be undertaken. ${ }^{134} \mathrm{He}$ has warned against traditional political affiliations, cautioning that in the future the church will be "flirting as little with the left as with the right." ${ }^{135}$ However, the ways in which relationships with these diverse groups will be developed remains to be seen. These conflicts are more likely to come to the forefront if and when there are major secular conferences on the environment in which the Holy See participates.

In addition, it remains to be seen which specific issues arise in the next few years that may involve the intervention of the Holy See on ecological matters. More generally, Pope Benedict XVI has identified the pressing issues of our time to be "witness to the One God and his commandments, the sanctity of life, the promotion of human dignity, the rights of the family, and the need to build a world of justice, reconciliation and peace for future generations." ${ }^{136}$ Thus, it is likely that

VICE, December 13, 2006 (available on line at www.catholic.org/international/ international_story.php) ("According to Pope Benedict XVI, the three major threats to world peace today are nuclear weapons, the unprecedented race for energy resources and the lack of respect for human rights."); Joe Sinasac, On Being Green, THE CATHourc Regrster, February 2, 2007 ("Pope Benedict XVI in his annual World Day of Peace message also drew links between proper ecological stewardship and our responsibility to each other."); Id. ("Pope Benedict XVI becomes even more pointed, challenging the world to curb its appetite for energy resources or reap the whirlwind."); and Paul Majendie, God Turns Green, Gelong AdverTiser, February 10, 2007 at 40 ("Pope Benedict XVI has called on every Catholic to become environmentally friendly and dedicated an entire section of his 2007 World Day of Peace message to what he called 'the ecology of peace."').

${ }^{133}$ See VALUes IN A TIME OF UpHeAvaL, supra note 61, at 154 (criticizing emphasis on population control at "the great conferences on world climate.").

${ }^{134}$ See id. at 28 , in which he asks, "[t] he triad 'peace, justice, and preservation of creation' is universally recognized, but its contents remain completely vague. What serves the cause of peace? What is justice? How are we to preserve creation in the best possible way?"

${ }^{135}$ FaIth and the Future, supra note 42 , at 104. See also JosePh Cardinal RatZinger, The Nature and Mission of Theology 81 (Trans: Adrian Walker) (1995) ("[T]he Church . . . cannot and must not become a political party.").

${ }^{136}$ Pope Benedict XVI, Letter of His Holiness Pope Benedict to the President of the Commission for Religious Relations with the Jews on the Occasion of the $40^{\text {th }}$ Anniversary of the Declaration "Nostra Aetate," October 26, 2005. 
the ecological issues that will garner Pope Benedict XVI's attention will be those that fit into this framework of priorities. There are a few possibilities that emerge. The first, as mentioned previously, is the need to address the ecological devastation that is caused by warfare. ${ }^{137}$ The second is the traditional intervention of the Holy See when issues of population control inevitably arise in international discussions about ecology. ${ }^{138}$ The third is the high profile question of global climate change. That issue has risen to prominence in the secular world of ecology, and, thus, it may spark more extensive papal commentary. ${ }^{139}$

\section{Other possibilities that may confront Pope Benedict XVI include:}

- aftermath of millennial debt forgiveness and the impact, if any, that this had has in the ability of impoverished nations to develop more secure food supplies via environmentally sustainable means; ${ }^{140}$

${ }^{137}$ Indeed, Pope Benedict XVI alluded to this in his 2006 Urbi et Orbi Easter Message, in which he prayed, "concerning the international crises linked to nuclear power, may an honourable solution be found for all parties, through serious and honest negotiations, and may the leaders of nations and of international organizations be strengthened in their will to achieve peaceful coexistence among different races, cultures, and religions, in order to remove the threat of terrorism." Pope Benedict XVI, Urbi et Orbi Message of His Holiness Pope Benedict XVI, Rome, April 16, 2006. See also Pope Benedict XVI, Address of His Holiness Benedict XVI at the Conclusion of the Recitation of the Holy Rosary, Rome, May 1, 2006 (speaking of the "need to convert to God, to God who is Love, so that the world may be freed from war and terrorism.").

${ }^{138}$ Indeed, Pope Benedict XVI has recently discussed the demographic situation of the $21^{\text {st }}$ century in terms quite different from those found in the usual analysis of population growth. See Pope Benedict XVI, Letter of His Holiness Benedict XVI to the Participants in the Twelfth Plenary Assembly of the Pontifical Academy of the Social Science, April 27, 2006:

While the statistics of population growth are indeed open to varying interpretations, there is general agreement that we are witnessing on a planetary level, and in the developed countries in particular, two significant and interconnected trends: on the one hand, an increase in life expectancy, and, on the other, a decrease in birth rates. As societies are growing older, many nations or groups of nations lack a sufficient number of young people to renew their population.

${ }^{139}$ As discussed in note 3, supra, the Pontifical Council for Justice and Peace will be studying the link between climate change and development at an international conference in April 2007.

${ }^{140}$ Pope Benedict XVI has already referred to this problem when he discussed "the Holy See's efforts to contribute to finding effective solutions to some of the more significant problems facing the international community in recent years, such as the scandal of continued widespread hunger, grave illness and poverty in large areas of our world." Pope Benedict XVI, Address of His Holiness Benedict XVI to H.E. Mr. Francis Rooney, New Ambassador of the United States of America to the Holy See, November 12, 
- international trade agreements and their intended and unintended environmental consequences as economic globalization advances; and

- ecumenical activities in the environmental realm.

Finally, it will be interesting to observe how Pope Benedict XVI addresses ecological concerns in his public writing, and whether these issues become the subject of any major encyclicals, or whether they are addressed more frequently via Vatican interventions in secular environmental conferences.

\section{Conclusion}

Pope Benedict XVI has, in the past, proven himself to be a very eloquent writer in praise of the natural world and all its goodness. As his papacy unfolds, the development of these early themes will be intriguing to follow. He has written, with much optimism that the Church "must arouse the voice of the cosmos itself, making it, too, glorious, beautiful, habitable, and beloved," 141 because, in his words:

Christian belief knows no absolute separation between spirit and matter, between God and matter. . . . The assumption of the cosmos, of matter, into the relationship with God is thus a confession of the Creator God and of the world as creation, of the oneness bestowed on all reality by the Creator Spiritus. It also forms a link between the Christian faith and the religions of the nations which, as cosmic religions, seek God in the elements of the world and are actually on his trail, albeit at a distance. It is, at the same time, an expression of hope for the transformation of the cosmos. ${ }^{142}$

To those who fear what may come next, he reassuringly professes that "God does not allow any part of his creation to sink silently into a past that has gone forever. He has created everything so that it should exist ... he has created everything so that all should be one and should belong to him."143

2005. He went on to note, "An adequate approach to these issues cannot be limited to purely economic or technical considerations, but demands broad vision, practical solidarity and courageous long-term decisions with regard to complex ethical questions: among the latter I think especially of the effects of the crushing debt that feeds the spiral of poverty in many less developed nations." Id.

141 The RATZINGER REPORT, supra note 71, at 129 (quoting earlier comment of Cardinal Ratziner in Das Fest des Glaubens). See also TruTH AND Tolerance, supra note 28, at 127 (urging "re-entry into the dance of the cosmos through ecstasy.").

142 Principles of Catholic Theology, supra note 47 , at 29.

${ }^{143}$ Seek That Which Is Above, supra note 27, at 36. 
'. 


\title{
Catholic Social Teaching and Its Impact on American Law: Some Observations on the Past and Reflections on the Future
}

\author{
Lucia A. Silecchia
}

\section{Introduction}

In recent years, greater attention has been paid to the influence of Catholic social teaching as a contributor to legal debates in American society, as scholars seek to understand the contribution that this tradition can make to help address the complex political, moral, and social issues that confront the modern world. ${ }^{1}$ The papacy of a politically knowledgeable, prolific, and peripatetic pope has brought the message of Catholic social thought to bear on social questions around the globe. ${ }^{2}$ More locally, American bishops have, in recent decades, issued pastoral letters and statements on such fundamental moral questions as the sanctity of human life, ${ }^{3}$ the gravity of war and peace, ${ }^{4}$ environmental

Lucia A. Silecchia is Associate Professor of Law, The Catholic University of America; J.D., Yale Law School; B.A. Queens College (C.U.N.Y.). I am very grateful to my research assistant, Nicole Stach, Columbus School of Law, Class of 2005, for her research assistance. I am also indebted to Stephen Young of the Catholic University Law Library for his help. Finally, I am deeply thankful to Dean Mark Sargent, Villanova Law School, and the Villanova Journal of Catholic Social Thought for the opportunity to participate in the conference for which this paper was prepared.

${ }^{1}$ For an extensive, classical discussion of this question, see e.g., Charles D. SKoK, Prudent Civil Legislation According to St. Thomas and Some Controversial American LAW (1967) (exploring relationships between law and the Catholic tradition, with particular emphasis on the teaching of St. Thomas Aquinas), and George V. DougherTy, The Moral Basis of Social Order According to St. Thomas (1941) (discussing teachings of St. Thomas Aquinas with regard to the interrelationships between justice, religion, and the social order).

2 The particular impact of Pope John Paul II's papacy on democratic political systems is studied more fully in George Weigel, Catholicism and Democracy in the Age of John Paul II, 4 Logos 36 (2001).

${ }^{3}$ See, e.g., National Conf. of Catholic Bishops, Living the Gospel of Life: A ChalLenge to American Catholics (1998) [hereinafter Living the Gospel of Life] and National Conf. of Catholic Bishops, Faithful for Life: A Moral Reflection (1995). See also United States Conf. of Catholic Bishops, A Matter of the Heart (2002).

${ }^{4}$ See, e.g., National Conf. of Catholic Bishops, The Harvest of Justice is Sown in Peace (1993); National Conf. of Catholic Bishops, The Challenge of Peace: God's 
responsibility, ${ }^{5}$ economic justice, ${ }^{6}$ and the responsibility of individuals and governments to assist the most vulnerable among us both nationally ${ }^{7}$ and globally. ${ }^{8}$ The American bishops have also explored the scope of responsibility for Catholic citizens as participants in political affairs. ${ }^{9}$ Undergirding this activity has been, of course, the Church's tradition of social teaching as explained most fully in the past century through a series of social encyclicals that articulate essential moral principles to guide decisions on social policy. ${ }^{10}$

As it has developed, Catholic social teaching clearly envisions a role for the Church to play in shaping society. This teaching is conscious

Promise and Our Response (1983) [hereinafter The Challenge of Peace]; National Conf. of Catholic Bishops, Sowing Weapons of WaR (1995); and Bishop Wilton D. Gregory, Statement on War with Iraq (March 19, 2003). See also Kenneth D. Wald, Religious Ethics and Public Opinion: The Impact of the Bishops' Peace Pastoral, 52 Rev. PoLITICS 112 (1992) (evaluating efficacy of bishops' statement on peace).

${ }^{5}$ See, e.g., United States Conf. of Catholrc Bishops, Global Climate Change: A Plea for Dialogue, Prudence, and the Common Good (2001), and National Conf. of CathoLiC Bishops, Renewing the Earth (1992).

${ }^{6}$ See, e.g., National Conf. of Catholic Bishops, Economic Justice for All (1986). This statement was evaluated at length in Charles E. Curran, Ethical Principles of Catholic Social Teaching Behind the United States Bishops'Letter on the Economy, 7 J. Bus. Eтнics 413 (1988). The extent to which the bishops' economic teaching is intended to have widespread effect is evaluated at length in Jeremy Waldron, Religious Contributions in Public Deliberations, 30 San Diego L. Rev. 817 (1993).

${ }^{7}$ See, e.g., National Conf. of Catholic Bishops, Renewing U.S. Leadership in REFUGeE Protection (2001).

${ }^{8}$ See, e.g., United States Conf. of Catholic Bishops, Millennium Challenge Account: A Proposed Conceptual Approach for Eligibility (2002), and National Conf. of Catholic Bishops, A Jubilee Call for Debt Forgiveness (1999).

${ }^{9}$ See United States Conf. of Catholic Bishops, Faithful Citizenship: Civic ResponSIBILITy for a New Millennium (1999) [hereinafter Faithful Citizenship] (copy on file with the author).

${ }^{10}$ This tradition is, in turn, deeply rooted in scriptural teachings that date back several millennia. See United States Catholic Conf., Sharing Catholic Social Teaching: Challenges and Decisions 1 (1998) [hereinafter Sharing Catholic Soctal TeachING], ("Catholic social teaching is a central and essential element of our faith. Its roots are in the Hebrew prophets who announced God's special love for the poor. ... It is founded on the life and words of Jesus Christ."); Robert J. Araujo, S.J., Christian Social Thought and American Public Policy: A Dialogue Between the Laity and the American State, 35 J. СнuRch \& STATE 751, 754 (1993) ("The general themes of social justice and fair play and how people ought to live with one another are major topics addressed in the Old and New Testament."); Id. at 759. ("The examination of Scripture illustrates that the teachings of Jesus addressed questions about justice which you see in our contemporary world."). See also Avery Cardinal Dulles, Catholic Social Teaching and American Legal Practice, 30 Fordham. URB. L.J. 277, 279 (2002) ("It seems safe to say that no other institution has developed a body of social teaching rivaling that of the Catholic Church in depth, coherence, and completeness."). 
that the Church's ultimate responsibility is not a worldly one, and it leaves considerable discretion to the judgment of the laity with regard to implementation. ${ }^{11}$ Yet, in spite of this, the Church's social teaching posits a role for itself that is active, optimistic, and increasingly ecumenical and global in perspective. The United States is, clearly, subject to the influence of this teaching. The interplay between Catholic social teaching and American law is a fascinating, complex, and, at times, tense relationship-a relationship to which these reflections are directed.

The first part of this discussion will explore how leading Church documents define the proper scope of influence for Catholic social teaching. After this brief background, the discussion will turn to reflection on the impact that Catholic social teaching has had on American law and politics. Most importantly it will focus on and explore three obstacles that have been barriers to a greater role for Catholic social thought in American legal and political discourse.

\section{The Role of Catholic Social Teaching as Articulated by the Social Encyclicals}

Over the years, the Church has developed a vision of its role in advancing its social teaching through law and other social institutions. As explained eloquently by Pope John XXIII, "the Church's teaching on social matters ... has truth as its guide, justice as its end, and love as its driving force." ${ }^{12}$ This proposition-that a religious body should have a share in the affairs of this world-was not entirely self-evident nor uncontroversial. ${ }^{13}$ The Church set out to establish that, although she is

\footnotetext{
${ }^{11}$ See notes 76-89, infra, and accompanying text.

${ }^{12}$ See Pope John XXIII, Mater et Magistra (1961), reprinted in Catholic Social Thought: The Documentary Heritage II 226, at 120-121 (David J. O'Brien \& Thomas A. Shannon eds., 1992) [hereinafter CA'ThOLIC Social Thought].

${ }^{13}$ See Pope John Paul II, Centesimus Annus (1991), reprinted in Catholic Social Thought, supra note 12, II 1, at 439. Pope John Paul II explains:
}

In Pope Leo XIII's time, [the] concept of the church's right and duty was far from being commonly admitted. Indeed, a two-fold approach prevailed: one directed to this world and this life, to which faith ought to remain extraneous; the other directed toward a purely otherworldly salvation, which neither enlightens nor directs existence on earth. The Pope's approach in publishing Rerum Novarum gave the church citizenship status.

Id. If 5 , at 443 . 
a religious institution, she nevertheless has a legitimate role to play in the legal and social arenas of the earthly world. ${ }^{14}$

\section{This theme has been developed extensively in encyclical teachings} but, perhaps, nowhere as eloquently as in Gaudium et Spes which declared that:

Christians, on pilgrimage toward the heavenly city, should seek and savor the things that are above. This duty in no way decreases, but rather increases, the weight of their obligation to work with all men in constructing a more human world. ${ }^{15}$

\footnotetext{
${ }^{14}$ The Church laid claim to this social expertise from the very earliest of the modern encyclicals. See Pope Leo XIII, Rerum Novarum (1891), reprinted in Catholic Social. THOUGH', supra note 12, II 13, at 19. ("[T] he Church uses its efforts not only to enlighten the mind, but to direct by its precepts the life and conduct of men."); Id. II 18, at 21 ("The things of this earth cannot be understood or valued rightly without taking into consideration the life to come, the life that will last forever."). See also POPE PIUS XI, QUADRAGEsimo AnNo (1931), reprinted in CATHolic Social Thought, supra note 12, II 41, at 50-51 (noting "it is our right and our duty to deal authoritatively with social and economic problems"); MATER ET MAGISTRA, supra note 12, II 239, at 122 ("[I]t is the Church's right and duty not only to safeguard principles relating to the integrity of religion and morals, but also to pronounce authoritatively when it is a matter of putting these principles into effect."); Pope John Paul II, Solicitudo Rei Socialis (1987), reprinted in Catholic Social Thought, supra note 12, II 8, at 398 (calling the Church's social doctrine "an application of the word of God to people's lives and the life of society, as well as to the earthly realities connected with them").

In an historical discussion, it has been noted that "[d]uring the Catholic Church's long history of involvement in temporal affairs, large-scale social, political, and legal issues have often been within the sphere of its competence and control. . . . Although it has not had ... widespread sociopolitical dominance for centuries, and no longer seeks it, the church continues to be concerned institutionally and intellectually with the welfare of the whole of humanity and the world, as though both were within its care." Angela C. Carmella, A Catholic View of Law and Justice, reprinted in ChristiAn PerSPECTIVES ON Legal. Thought 255, 256 (Michael W. McConnell et. al. eds., 2001). See also id. at 259 ("[A]ny [secular] influence it has in temporal matters is a by-product of its religious ministry.") and Dulles, supra note 11, at 278 ("The Bible holds out to us not only the vision of individual salvation, but also the vision of a society of peace and love.").

${ }^{15}$ Second Vatican Council, Gaudium et Spes: Pastoral Constitution on the Church in the Modern World (1965), reprinted in Catholic Social Thought, supra note 12, Tt 57, at 203, [hereinafter Gaudium ET Spes]. See also RERum Novarum, supra note 14, 9l 23, at 25 ("Neither must it be supposed that the solicitude of the Church is so occupied with the spiritual concerns of its children as to neglect their interests temporal and earthly."); GAUDIUM ET SPES, supra, at II 39, at 189 ("[T] must not weaken but rather stimulate our concern for cultivating this one."); Id. II 40, at 189 ("[T] he earthly city and the heavenly city penetrate each other."); POPE PAUL VI, Octogesima Adveniens (1971), reprinted in Catholic Social Thought, supra note 12, II
} 
That is, the Church has articulated a vision that suggests that it is precisely concern for religious matters that should justify, mandate, and motivate involvement in the affairs of this world. In the very earliest of the modern encyclicals, Rerum Novarum, Pope Leo XIII wrote, "Neither must it be supposed that the solicitude of the Church is so occupied with the spiritual concerns of its children as to neglect their interests, temporal and earthly." 16 This link was elaborated on much more fully in recent times. In Mater et Magistra, for example, Pope John XXIII wrote:

Hence, although Holy Church has the special task of sanctifying souls and of making them sharers of heavenly blessings, she is also solicitous for the requirements of men in their daily lives, not merely those relating to food and sustenance, but also to their comfort and advancement in various kinds of goods and in varying circumstances of time. ${ }^{17}$

\section{He went on to say that:}

Realizing all this, Holy Church implements the commands of her founder, Christ, who refers primarily to man's eternal salvation when he says, 'I am the Way, and the Truth, and the Life' and elsewhere 'I am the Light of the World.' On other occasions, however, seeing the hungry crowd, he was moved to exclaim sorrowfully, 'I have compassion on the crowd,' thereby indicating that he was also concerned about the earthly needs of mankind. ${ }^{18}$

Similar themes have been echoed in all the major encyclicals that have followed, as the Church links her salvific mission to the task of providing guidance on the affairs of this world. ${ }^{19}$ Two of the greatest examples

1 at 265 ("The Church . . . travels forward with humanity and shares its lot in the setting of history.") and PoPe PaUL VI, Evangeli Nuntiandi (1971), reprinted in CathoLIC Social THOUGHT, supra note 12, II 1, at 303, II 29, at 313 ("[E]vangelization would not be complete if it did not take account of the increasing interplay of the Gospel and of man's concrete life, both personal and social.").

${ }^{16}$ Rerum Novarum, supra note 14, II 23, at 25.

${ }^{17}$ MATER ET MAGistra, supra note $12, \mathbb{T} 3$, at 84.

${ }^{18}$ Id. II 4, at 84. See also CenTesimus ANNUS, supra note 13, gI 57, at 481 ("Christ's words, 'as you did it to one of the least of these my brother, you did it to me' .. . were not intended to remain a pious wish but were meant to become a concrete life commitment.").

${ }^{19}$ See Mater et Magistra, supra note 12, II 222, at 120 ("[T]he social teaching proclaimed by the Catholic Church cannot be separated from her traditional teaching regarding man's life."); GAUDIUM ET SPES, supra note 15, gा 4, at 167 ("[T] he Church has always had the duty of scrutinizing the sign of the times and of interpreting them in light of the gospel."); Octogesima AdVENIENS, supra note 15, II 1, at 265 ("The Church . . . travels forward with humanity and shares its lot in the setting of history."); SYNOD of Bishops, Justice IN THE WORLD, reprinted in CATHOLIC Social ThoughT, supra note 12, at 
of this can be found in those places where the Church asserts basic human rights, and where she asserts that to be legitimate, civil laws must conform to unchanging moral principles against which they will be judged.

In Gaudium et Spes, for example, the Church set forth a detailed list of basic human rights. Far more extensive then the American Bill of Rights, this listing embodied the negative freedoms from harm common in civil lists of rights. However, it also went further and listed affirmative rights to the tangible and intangible goods of the world. It summarized human rights as including the requirements that:

[T]here must be made available to all men everything necessary for leading a life truly human, such as food, clothing, and shelter; the right to choose a state of life freely and to found a family; the right to education, to employment, to a good reputation, to respect, to appropriate information, to activity in accord with the upright norm of one's own conscience, to protection of privacy, and to rightful freedom in matters religious too. ${ }^{20}$

Although the listing clearly articulated a right to freedom of religion, ${ }^{21}$ the rest of the listing is entirely secular in nature. This asserted, in very clear terms, that Catholic social teaching claims for itself the

288,289 (1971) ("Action on behalf of justice and participation in the transformation of the world fully appear to us as a constitutive dimension of the preaching of the Gospel."); Id. at 294 ("The Church has received from Christ the mission of preaching the Gospel message, which contains a call to man to turn away from sin to the love of the Father, universal brotherhood, and a consequent demand for justice in the world."); Sollicitudo Rei Socialis, supra note 14, II 41, at 424 ("[T] he Church is an 'expert in humanity,' and this leads her necessarily to extend her religious mission to the various fields in which men and women expend their efforts in search of the always relative happiness which is possible in this world, in line with their dignity as persons.") and Centesimus Annus, supra note 13, II 5 , at 443 ("[T] teach and to spread her social doctrine pertains to the church's evangelizing mission and is an essential part of the Christian message, since this doctrine points out the direct consequences of that message in the life of society.").

${ }^{20}$ Gaudium ET Spes, supra note 15, II 26, at 181. Pope John Paul II also outlined basic human rights in Centesimus Annus in which he listed those rights:

Among the most important of these rights, mention must be made of the right to life, an integral part of which is the right of the child to develop in the mother's womb from the moment of conception; the right to live in a united family and in a moral environment ...; the right to develop one's intelligence and freedom in seeking and knowing the truth; the right to share in the work which makes wise use of the earth's material resources, and to derive from that work the means to support oneself and one's dependents; and the right freely to establish a family.... [T] he source and synthesis of these rights is religious freedom.

Centesimus Annus, supra note 13, II 47, at 474.

${ }^{21} I d$. 
authority to articulate basic fundamental rights and to assert the nonnegotiable obligation of civil authority to defend and protect those rights. $^{22}$

Later the Church's teachings on the relationship between moral law and civil law were developed more fully. One can find in Evangelium Vitae the most thorough explication of the complex and, at times, contentious relationship between the moral law and positive civil law. In keeping with the Church's natural law tradition, Evangelium Vitae explains that "[t]he doctrine on the necessary conformity of civil law with the moral law is in continuity with the whole tradition of the Church." ${ }^{23}$ It goes on to warn that a law that violates the moral order is, in fact, not "law" at all:

The basis of these values cannot be provisional and changeable 'majority' opinions, but only the acknowledgement of an objective moral law which, as the 'natural law' written in the human heart, is the obligatory point of reference for civil law itself. ${ }^{24}$

This reiterates the much earlier declaration in Rerum Novarum that "the laws and judgment of men must give place to the laws and judgment of Christ," 25 a declaration echoed countless other times in the Church's social teachings. ${ }^{26}$

\footnotetext{
${ }^{22}$ See also JUSTICE IN THE WORLD, supra note 19, at 294 ("[T] he Church has the right, indeed the duty, to proclaim justice on the social, national, and international level, and to denounce instances of injustice, when the fundamental rights of man and his very salvation demand it.").

${ }^{23}$ Pope John Paul II, Evangelium Vitae, II 72, at 118 (Daughters of St. Paul) (1995). See also id. If 62, at 102 (noting that "no law whatsoever can ever make licit an act which is intrinsically illicit").

${ }^{24}$ Id. If 70, at 115. It has been observed that Evangelium Vitae "raised the philosophical stakes by arguing that democracies risked self-destruction if objectively moral wrongs were installed as constitutional 'rights." Weigel, supra note 2, at 51.

${ }^{25}$ Rerum Novarum, supra note 14 , II 19 , at 23.

${ }^{26}$ See, e.g., GAUdIUM ET SPES, supra note 14, II 79, at 221 (noting "the permanent binding force of universal natural law and its all-embracing principles"). See also Carmella, supra note 14, at 262. See also id. (observing that "the search for objective moral principles remains important and necessary in the church's social thought. For if no intelligible moral order exists, then the transcendent worth of all persons cannot be acknowledged and promoted.") and $i d$. at 269-270 ("A Catholic analysis and critique of the civil or positive law ... starts from the premise that there is a natural law written on the human heart that is intelligible through reason, and knowable without revelation against which all civil law is measured."); Robin W. Lovin, Church and State in an Age of Globalization, 52 DePauL L. Rev. 1, 4 (2002) (summarizing classical view of St. Thomas Aquinas that "[a] law that is not ordered toward the common good is not a law, and the one who promulgates such a law is not a legitimate ruler, but a tyrant").
} 
Thus, the Church articulates three aspects of its role in the shaping of law and society. First, it asserts a legitimate role for the Church in worldly affairs. Next, it confirms its authority and responsibility to articulate the minimal human rights and protections required for the creation of a just order. Finally, in keeping with the natural law tradition, it argues that a law is not legitimate unless it is consistent with unchangeable moral values.

Yet, at the same time that the Church lays claim to such a voice in shaping the laws that govern peoples, it simultaneously imposes two significant limits on the scope and sphere of its influence.

First, Catholic social teaching cautions against over-reliance on civil law as a way to advance justice. Church teaching advocates the use of law to safeguard human rights through compliance with moral law and supports the use of law to provide fair and just ways for maintaining civil order and providing for the general welfare. Indeed, it urges that "[t]he Christian has the duty to take part in ... the organization and life of political society." 27 Yet, the Church's social teaching also warns that law not be viewed as the sole tool for advancing the common good. Rather, it cautions "that the law must not undertake more, nor go further, than is required for the remedy of the evil or the removal of the danger." 28

Because, as Octogesima Adveniens teaches, "[t]he domain of politics is wide and comprehensive, but it is not exclusive," ${ }^{29}$ the Church's teaching is directed to all the institutions that can shape society. These include, but are not limited to, families, religious communities, schools, social and fraternal organizations, private charitable organizations, lay professionals in all fields, and, in some ways most importantly, individuals. ${ }^{30}$

${ }^{27}$ Octogesima Adveniens, supra note 15, II 24, at 274. Octogesima Adveniens goes on to state the importance of politics, noting that "[p]olitical power . . . is the natural and necessary link for ensuring the cohesion of the social body." Id. II 46, at 282.

${ }^{28}$ Rerum Novarum, supra note 14, II 29, at 28.

${ }^{29}$ OCTOGESIMA ADVENIENS, supra note 15, gl 46, at 282.

${ }^{30}$ In a powerful expression of the place of the individual in advancing the social good, Pope Paul VI wrote:

It is not enough to recall principles, state intentions, point to crying injustices, and utter prophetic denunciations; these words will lack real weight unless they are accompanied for each individual by a livelier awareness of personal responsibility and by effective action. It is too easy to throw back on others responsibility for injustices, if at the same time one does not realize how each one shares in it personally, and how personal conversion is needed first.

Id. II 48 , at 284 . 
The Church urges that all of these components of society work tirelessly to advance the principles of social justice and resist the temptation to rely solely on law toward that end. Indeed, it is telling that this body of doctrine is not called "Catholic legal teaching," but is, instead, called "Catholic social teaching." This implies the need to look beyond law for social advancement-a theme echoed often by modern popes. In 1931, Pope Pius XI warned, in Quadragesima Anno, that while "[j]ustice alone can, if faithfully observed, remove the causes of social conflict, [it] can never bring about a union of minds and hearts. . . If this bond is lacking, the best of regulations come to naught, as we have learned by too frequent experience." ${ }^{31}$ Pope John Paul II echoed a similar sentiment when he warned, in Dives in Misericordia, "[t]he experience of the past and of our own time demonstrates that justice alone is not enough ... if that deeper power, which is love, is not allowed to shape human life in its various dimensions." 32 This caveat should not imply that law is a tool to be ignored in the effort to build justice. ${ }^{33}$ However, it is not always the only or best way to do so. As Pope John Paul II reasoned in Evangelium Vitae,

[N] egative moral precepts have an extremely important positive function. The "no" which they unconditionally require makes clear the absolute limit below which free individuals cannot lower themselves. At the same time they indicate the minimum . . . from which they must start out in order to say "yes" over and over again, a "yes" which will gradually embrace the entire horizon of the good. ${ }^{34}$

Thus, the first caveat is that Catholic social teaching-while often directed toward the law-is not limited to it.

\footnotetext{
${ }^{31}$ See also id. II 142, at 76 (noting that it is "the charity of Christ [ ] which alone has power to incline men's hearts and wills firmly and gently to the laws of equity and justice").

${ }^{32}$ Pope John Paul II, Dives in Misericordia, II 12 (1980). See also Justice in the WORLD, supra note 20, at 293 ("[L]ove implies an absolute demand for justice, namely a recognition of the dignity and rights of one's neighbor. Justice attains its inner fullness only in love.") and Evangelir NunTIANDI, supra note 15, II 36, at 316 ("[T] he best structures and the most idealized systems soon become inhuman if the ... inclinations of the human heart are not made wholesome, if those who live in these structures or who rule them do not undergo a conversion of heart and of outlook.").

${ }^{33}$ Indeed, in Rerum Novarum, Pope Leo XIII, argued an important role for the State and identified its "first duty ... should be to make sure that the laws and institutions the general character and administration of the commonwealth, shall be such as to produce of themselves public well-being and private prosperity." RERUM NovARUM, supra note 14 , II 26 , at 26.

${ }^{34}$ Evangelium Vitae, supra note 23, II 75, at 123.
} 
The second limitation that Church teaching places on its influence is one particularly relevant to the American experience. The Church has consistently disavowed a desire to adopt allegiance to specific political parties or systems of government. This renunciation of such a role has been consistent throughout the modern encyclicals. For example, in Gaudium et Spes, the Second Vatican Council declared:

The role and competence of the Church, being what it is, she must in no way be confused with the political community nor bound to any political system. For she is at once a sign and a safeguard of the transcendent character of the human person.... In their proper spheres, the political community and the Church are mutually independent and self-governing. Yet by a different title each serves the personal and social vocation of the same human beings. ${ }^{35}$

\section{Likewise, in Centesimus Annus, Pope John Paul II noted:}

The church respects the legitimate autonomy of the democratic order and is not entitled to express preferences for this or that institutional or constitutional solution. Her contribution to the political order is precisely her vision of the dignity of the person revealed in all its fullness in the mystery of the incarnate Word. ${ }^{36}$

The Church sees its place as neither beholden to nor bound by any particular order. Instead, while contributing a moral framework of law and policy making, Catholic social teaching remains hospitable to a

\footnotetext{
${ }^{35}$ GaUdium ET SPeS, supra note 15 , II 76, at 218. See also id. II 42, at 191 (noting that the Church "is bound to no particular form of human culture, nor to any political, economic, or social system"); Id. at 216 ("[T] he choice of government and the method of selecting leaders are left to the free will of citizens."); Id. II 74, at 216 ("The practical ways in which the political community structures itself and regulates public authority can vary according to the particular character of a people and its historical development."); Pope Paul VI, Populorum Progressio (1967), reprinted in Catholic Social Thought, supra note 12, II 1, at 240, II 13, at 243 ("Founded to establish on earth the kingdom of heaven and not to conquer any earthly power, the Church clearly states that the two realms are distinct, just as the two powers, ecclesiastical and civil, are supreme, each in its own domain.") and OCTOGESIMA AdVEnIENS, supra note 15, II 24, at 274 (noting that, with respect to forms of governance, "[v]arious models are proposed, some are tried out, none of them gives complete satisfaction and the search goes on between ideological and pragmatic tendencies").

${ }^{36}$ Centesimus Annus, supra note 13, II 47, at 475. See also Sollicitudo Rei Socialis, supra note 14 , II 41 , at 424 :
}

[T] he Church does not propose economic and political systems or programs, nor does she show preference for one or the other, provided that human dignity is properly respected and promoted, and provided she herself is allowed the room she needs to exercise her ministry in the world. 
wide variety of political regimes and parties. ${ }^{37}$ This respectful distance from the civil sphere reflects the Church's understanding that Caesar is to be given a wide berth in his realm of competence as long as his laws do not interfere with the Church's prerogatives nor trample on the dignity and rights of peoples. ${ }^{38}$

\section{The Impact of Catholic Social Teaching on American Law and Politics.}

With this very brief background on the Church's vision of her role in shaping law, and the self-imposed limitations on that role, it is possible to reflect on the influence that it has had on American law in the past, and to offer some reflections on the role of that influence in the future. ${ }^{39}$

\section{A. Historical Reflections}

It is clear that there are aspects of Catholic social teaching that, historically, have had a great impact on American law and policy. ${ }^{40}$ In many ways, the most dramatic debut of the Catholic Church in legal

\footnotetext{
${ }^{37}$ See, e.g., QuAdRAGESImo ANNo, supra note 14, II 2, at 42, II 10, at 44 (noting that the classic Rerum Novarum "sought help neither from liberalism nor socialism").

${ }^{38}$ Christopher T. Carlson, Church and State: Consistency of the Catholic Church's Social Teaching, 35 CaTH. LAw. 339, 347 (1994) ("The Church judges a particular law, course of conduct, or omission on whether it is in discord or harmony with justice, human rights, or man's attainment of an eternal home."); and Carmella, supra note 14, at 267 ("Determining what aspects of the common good are properly within the state's function, and what should be left to civil society may vary from culture to culture, but that function always includes the maintenance of public peace, public morality, and minimum standards of justice.").
}

${ }^{39}$ Indeed, the American bishops themselves have been forced to reflect on this issue as they plan for the future role to be played by Catholic social teaching in modern life and observe the necessity to provide more extensive education to Catholic laity in this area. See Sharing Catholic Social Teaching, supra note 10 (reporting American bishops reflections on the role of Catholic social teaching in American life). In the modern context, for an excellent collection of essays on the role of Catholic teaching in various political contexts, see generally The Catholic Church, Morality, and Politics (Charles E. Curran \& Leslie Griffin, eds. 2001); Principles of Catholic Social Teaching (David A. Boileau, ed. 1994) and When Conscience and Politics Meet: A Catholic View (ProCEEDINGS of the Wethersfield Institute) (1992) Thereinafter When Conscience and Politics Meetr].

${ }^{40}$ Indeed, much has been written about application of Catholic social teaching in various substantive contexts. See, e.g., Terry Coonan, There Are No Strangers Among Us: Catholic Social Teaching and U.S. Immigration Law, 40 CATH. LAW. 105 (2000) (addressing impact of Catholic social teaching on American immigration law); Michael Scaperlanda, Who Is My Neighbor?: An Essay on Immigrants, Welfare Reform, and the Constitution, 29 CoNN. L. REv. 1587, 1612-1624 (1997) (exploring Catholic social teaching vís a vis immigration policy); Dennis P. McCann, Catholic Social Teaching and the 
and political affairs was connected to the natural bond felt between the American Catholic Church and its many working class immigrant members. ${ }^{41}$ Unlike many European nations in which the Catholic Church and its leaders had been involved in affairs of state for centuries, the Catholic Church was, in many ways, an outsider to the American legal and political system in the eighteenth and much of the nineteenth centuries. ${ }^{42}$ Naturally, there were prominent Catholic leaders who involved themselves in the political and social debates of their time. But, because of its small population, the early American Catholic Church was not, as it was in Europe, a highly influential player in many legal and political affairs. Furthermore, underlying currents of anti-Catholic sentiment and suspicion curbed the ability of what many saw as a "foreigners" church to take a major role on the national stage. ${ }^{43}$

Economics of Health Care Management, 6 ChRISTIAN BIOETHICs 231 (2000) (discussing relationship between Catholic social teaching and health care); Robert A. Destro, The Religious Foundations of Civil Rights Law and the Study of Law and Religion in an Interdisciplinary Framework, 5 J.L. \& REL. 39 (1987) (studying connections between religion and civil rights law); Kenneth R. Himes, Rights of Entitlement: A Roman Catholic Perspective, 11 Notre Dame J. L., Ethics \& Pub. Pol'y 507 (1997) (exploring Catholic perspective on public assistance programs) and William W. Garnett, Christian Witness, Moral Anthropology, and the Death Penalty, 17 Notre Dame J. L., Ethics \& Pub. PoL'y 541 (2003) (studying impact of religious perspectives on death penalty debate).

${ }^{41}$ For a helpful historical overview of the connections between Catholicism and early American political life, see generally TIMOTHY A. ByRNes, CATHOLIC Bishops IN AMERICAN Politics 11-34 (1991).

42 See, e.g., John Courtney Murray, S.J., We Hold These Truths: Catholic Reflections on the American Proposition 20 (1960) (noting that in the United States "the Protestant was the native and the Catholic the immigrant, in contrast to Europe where the Catholic first held the ground and was only later challenged"); James M. Powell, Catholics and American Politics: Exploding the Myths, AmERICA, August 3, 1996 at 8 (noting that while "[p]rior to the Civil War, Catholics played only a minor role in U.S. politics," all this changed when "[i]mmigration completely altered the Catholic role in politics"); Winnifred Fallers Sullivan, Indifferentism Redux: Reflections on Catholic Lobbying in the Supreme Court of the United States, 76 Notre Dame L. Rev. 993, 994 (2001) ("For most of American history, Catholics have not been understood to occupy a central part in the history of American religion. Until quite recently in fact, as recently perhaps as the 1970's, American Catholics were a footnote to the story of American religion because 'American religion' was assumed to mean mainstream Protestant Christianity."); and A. James Reichley, Religion and the Future of American Politics, 101 POL. ScI. Q 23, 32 (1986) ("The Catholic hierarchy, while socially influential, up to the 1950's generally maintained a low profile in politics.").

${ }^{43}$ See Bishop John Ireland, Catholicism and Americanism (August 11, 1913), reprinted in Thomas J. Massaro \& Thomas A. Shannon, American Catholic Social TeachING 25, 30-31 (2002), observing: 
However, whether by coincidence or providence, the late nineteenth century saw a new wave of American immigration at the same time that saw the birth of the modern social encyclicals defining the role and responsibility of the Church as a participant in social affairs. Immigrating from many predominantly Catholic countries such as Italy, Ireland, and Poland, and settling in predominantly urban areas, it was natural for these new waves of immigrants to embrace their old faith in their new country and, in turn, for that Church to play a pastoral role in improving their plight. ${ }^{44}$ This launched the Church's activity in two large-scale early efforts that brought Catholic social principles to bear on American law and policy. The first was the involvement of late nineteenth-century Catholic leaders in advocating the rights of Catholics to educate their children as they saw best, and the second was the involvement of Catholic leaders in the labor movements of the early twentieth century.

With regard to the former, the Church championed the preeminence of the family as the primary unit of society. ${ }^{45}$ Catholic social teaching consistently defends the family from impermissible intrusions by state authority. ${ }^{46}$ Indeed, as taught in Rerum Novrum, "the idea, then, that the civil government should, at its own discretion, penetrate and pervade the family and the household, is a great and pernicious mis-

The charge is made, if not anti-American, the Catholic Church is un-American-it is in America an alien institution. More definitely the charge is this: the Catholic Church does not bear the stamp, "Made in America." It is un-American to go across the Atlantic or the Pacific for aught that America uses or needs-even for its religion.

See also Reichley, supra note 42, at 32 ("Until quite recently, the Catholic Church in America regarded itself as an 'immigrant' Church.").

${ }^{44}$ See RERum Novarum, supra note 14, II 24, at 25 (noting that "the Church intervenes directly in the interest of the poor, by setting on foot and keeping up many things which it sees to be efficacious in the relief of poverty").

${ }^{45}$ See, e.g., Rerum Novarum, supra note 14, If 9, at 18 (calling the family "a true 'society,' anterior to every kind of State or nation, with rights and duties of its own, totally independent of the commonwealth"); GAUDIUM ET SPES, supra note 15, II 52, at 200 ("The family is the foundation of society."); PoPe John PaUl II, Laborem Exercens: On Human Work (1981) in Catholic Social Thought, supra note 12, II 10, at 364 ("[T] he family constitutes one of the most important terms of reference for shaping the social and ethical order of human work.") and Sharing Catholic Social TEaching, supra note 10, at 4-5 ("The family is the central social institution that must be supported and strengthened, not undermined.").

${ }^{46}$ ReRUM Novarum, supra note 14, II 10, at 18 (stating that if a family, by associating with a state, "experienced at the hands of the State hindrance instead of help, and found their rights attacked instead of being protected, such associations were rather to be repudiated than sought after"). 
take. ${ }^{27}$ In light of this, Church teaching asserts the rights of parents to make all those decisions central to the raising of their children. Essential to this group of decisions is the prerogative of parents to educate their children in accordance with their values and beliefs. ${ }^{48}$

Often, the Church faced situations in which the educational system in particular communities was, in the view of Catholic parents, biased against their religious beliefs, hostile to their immigrant status, or both. ${ }^{49}$ The Church thus involved itself in advocating the rights of parents to establish and then educate their children in a system of religious schools that were more supportive of their beliefs. To a large extent, this involvement was successful, and it resulted in the creation of an extensive parochial school system. More importantly, however, it provides a powerful example of how American Catholic leaders were able to translate a core tenant of Catholic social tradition-the primacy of family-into concrete legal action.

In addition, most Catholic immigrants were members of the working class. Because of this, the Church publically endorsed legal measures to prevent the exploitation of workers and supported nascent union movements that collaborated in this mission. ${ }^{50}$ It paid particular attention to

\footnotetext{
${ }^{47} I d$. II 11 , at 18.

${ }^{48}$ See Richard H. Tierney, S.J., The Needy Family and Institutions (October 27, 1914), reprinted in CATHOLIC Social TEACHING, supra note 12, at 39, 40 ("The family is the social unit, the basis of civil society ... [C]ivil society can interfere with the control and education only so far as may be necessary to prevent neglect of parental duty in these matters. The control and education of offspring pertain to parents by a natural right emphasized, at least indirectly, by a positive divine command."); and FAITHFUL CITIZENSHIP, supra note 9 , at 9 ("The education of children is a fundamental parental responsibility.... All parents-the first most important educators-should have the opportunity to exercise their fundamental right to choose the education best suited to the needs of their children.").

${ }^{49}$ Sullivan, supra note 42, at 994 ("Religion was expelled from public schools, not because of hostility to religion, but because of hostility toward Catholics and fear that Catholics would demand and be given equal time and money. The Roman Catholic school system developed in response to this Protestant attitude.").

${ }^{50}$ See, e.g., BYRNEs, supra note 41, at 18 ("Given that the vast majority of immigrant Catholics belonged to the working class, this ... came to require episcopal support of organized labor."); William F. Ryan, S.J., Has Catholic Social Teaching Had Significant Influence? Reflections on a Century-Old Tradition, 23 EGLISE ET THEOLOGIE 13, 18 (1992) (noting the Catholic Church's "generally friendly and supportive stance toward labor unions"); ReRUM Novarum, supra note 14, II II 36-38 at 32-34 (outlining benefits and roles of labor unions and workers' associations); QUADRAGESIMO ANNo, supra note 14, II 33, at 48 (observing, with approval, that after Quadragesimo Anno, "the clergy and many of the laity devoted themselves everywhere with admirable zeal to the creation
} 
those aspects of the workplace that were perceived to be detrimental to the health, safety, and morals of vulnerable children or those that were harmful to family life. ${ }^{51}$ The timing of the Church's involvement in labor causes is directly tied to the waves of Catholic immigration to the United States. However, it is likely not mere coincidence that this involvement came on the heals of Rerum Novarum, the first great social encyclical that championed the rights and dignity of the working class, railed against their exploitation, ${ }^{52}$ and asserted that "public administration must duly and solicitously provide for the welfare and the com-

of . . . unions, which in turn became instrumental in building up a body of truly Christian workingmen"); GAUDIUM Eт SPES, supra note 15, II 68, at 212 ("Among the basic rights of the human person must be counted the right of freely founding labor unions."); LABOREM EXERCENS, supra note 45, II 20, at 380-382 (discussing benefits of, and rights to unions while, at the same time, warning of potential abuses); and CENTESIMUs ANNUS, supra note 13, If 7, at 444 (discussing "the church's defense and approval of the establishment of what are commonly called trade unions").

51 This concern with the impact of working conditions on such intangibles as employees' faith and morals was articulated clearly in Rerum Novarum, which warned of situations in which:

[C]ircumstances were such that among the laboring population the ties of family life were relaxed; if religion were found to suffer through the workmen not having time and opportunity to practice it; if in workshops and factories there were dangers to morals through the mixing of the sexes or from any occasion of evil; or if employees laid burdens upon the workmen which were unjust or degraded them with conditions that were repugnant to their dignity as human beings; finally, if health were endangered by excessive labor, or by work unsuited to sex or age - in these cases there can be no question that, within certain limits, it would be right to call in the help and authority of the law.

Rerum Novarum, supra note 14, II 29, at 28. See also Id. II 33, at 30-31 (discussing particular concerns arising with respect to child labor); and QUADRAGESIMO ANNO, supra note 14 , IT 135 , at $72-73$ :

The mind shudders if we consider the frightful perils to which the morals of workers ... and the virtue of girls and women are exposed in modern factories; if we recall how the present economic situation and above all the disgraceful housing conditions pose to the family tie and family life; if we remember the insuperable difficulties placed in the way of a proper observance of the holy days.

${ }^{52}$ See, e.g., Introduction in Catholic Social Thought, supra note 12 (noting that while Rerum Novarum "initially received only limited attention in the United States... [1]ater, during the progressive era of Theodore Roosevelt and Woodrow Wilson, a few Catholic reformers, led by John A. Ryan, drew on the encyclical to encourage Catholic support for social reform"); Id. ("In the 1930's ... a significant number of priests, religious, and lay people found support for union organizing, social action and New Deal politics in Catholic social teaching, now supplemented by Pope Pius XI's 1931 encyclical Quadragesimo Anno."); QuADRAGESIMO ANNO, supra note 14, II 12, at 44 (claiming that Rerum Novarum was "welcomed by Christian workingmen, who felt themselves vindicated and defended by the highest authority on earth, and by all those devoted men whose concern it had long been to better the conditions of labor. . . All of these men have ever held the encyclical in the highest esteem."); and id. II 28, at 47 (noting that as a consequence of Rerum Novarum, "there has arisen a new branch of jurisprudence 
fort of the working people, or else that law of justice will be violated which ordains that each shall have its due."

This involvement of the Church in labor concerns may have been more diffuse than its involvement in education initiatives because the range of issues involved in the labor movement was far broader. However, this activity was important in establishing the Church's position in national political discourse. While many of the disputes regarding education could be resolved on the local level by local bishops, labor was an issue national in scope. This brought the influence of Catholic teaching to bear on a national, highly-visible stage. In addition, it tapped into the Church's teachings on labor - the social issue to which late nineteenth and early twentieth century Catholic social thought paid the most direct attention.

While their involvement in these two issues may have marked the debut of the Catholic Church as a direct participant in American political and legal life, this was the mere prelude to further activity in this field. Since then, there has, undeniably, been a very public and significant contribution of the Church's social teaching to American legal and political developments.

On a practical level the Catholic Church in the United States-as well as in many other nations-is the single largest non-governmental provider of social services. ${ }^{54}$ This has provided the Church with hands-on experience in applying its social theories in such areas as health care, education, social service, immigration policy, and drug treatment. As a result, when these issues are subject to legal regulation or policy initiatives, the Catholic Church is a participant not merely as an aloof theorist, but also as an experienced provider of services. ${ }^{55}$ This expands

unknown to earlier times, whose aim is the energetic defense of those sacred rights of the workingman").

${ }^{53}$ Rerum Novarum, supra note 14, II 27 , at 26.

54 This practical aspect of the Church's social mission was noted in John Paul II, Evangelium Vitae, supra note 23, II 27 at 49, in which Pope John Paul II rejoiced in the fact that: "[T]he Church has always been in the front line in providing charitable help: so many of her sons and daughters ... have consecrated and continue to consecrate their lives to God, freely giving of themselves out of love for their neighbor, especially for the weak and needy.'

${ }^{55}$ See FAITHFUl CITIZENSHIP, supra note 9, at 5 ("Our community also brings broad experience in serving those in need. The Catholic community educates the young, cares for the sick, shelters the homeless, feeds the hungry, assists needy families, welcomes 
the scope of its expertise and its ability to participate as an informed party to social and legal debate. As the American bishops explained:

The history of the Church reveals a long tradition of defending those living in poverty, supporting charitable institutions, and promoting justice. Many religious orders were established on the principles of sharing the goods of the earth with the poor and of recognizing the essential dignity of human persons without regard to their economic or social status. In most parts of the world, the first hospitals, orphanages, schools, and social service centers were founded by the Church.... Faithful to this tradition, the Catholic Church in the United States now sponsors the largest voluntary network of social services, health care and education in the United States. As a result of the Church's efforts, greater recognition has been given to the inviolability of human life, the sanctity of marriage, the dignity of women, and the value of human worth. ${ }^{56}$

In addition, the Church's social teaching has made it the leader in the defense of the life of the very youngest and the very oldest members of American society. This issue-central to the Church's teaching on human life and dignity - has, in recent years, been the single most visible issue on which the Church has been in the forefront. ${ }^{57}$ While the right to life is by no means an exclusively Catholic question as it is often portrayed ${ }^{58}$ it is undeniable that the Church is by far the largest of the consistently vocal advocates on this question. ${ }^{59}$ Because of the high

refugees, and serves the elderly.... [W]e have the practical expertise and everyday experience to enrich public debate.").

${ }^{56}$ United States Conf. of Bishops, In All Things Charity: A Pastoral Challenge for THE New Millennium 4 (1999). See also id. at 9-15 (describing charitable activities of Catholic priests, religious orders, lay associations, Catholic Charities, the Catholic Campaign for Human Development, and Catholic Relief Services).

57 See, e.g., BYRNES, supra note 41, at 57 (calling Roe v. Wade an event that "thrust abortion onto the national political stage, and in time, gave rise to political developments that brought the Catholic hierarchy more actively into national electoral politics"); and Reichley, supra note 42, at 33 ("In January 1973, the Supreme Court decision establishing a virtually unlimited right to abortion brought the church hierarchy openly and vigorously into national politics.").

${ }^{58}$ See LIVING THE GoSPEL OF LIFE, supra note 3, at 3. ("The inherent value of human life, at every stage and in every circumstance, is not a sectarian issue any more than the Declaration of Independence is a sectarian creed.").

${ }^{59}$ See William Bentley Bell, The Effect of Judicial Decisions on Catholics in. WHEN Conscience and Politics Meet, supra note 39:

Orthodox Catholics, in the 1950's, 1960's, and 1970's were almost the sole opponents of abortion and its legalization. They, more than any other body of citizens today, are chiefly identified in the public consciousness as defenders of the right to life. Roe $v$. Wade and its successor decisions inevitably propelled orthodox Catholics not merely into resistance to the abortion movement but to the all-out war against it. It is the Catholic presence in that war, more than any other presence, which has produced a wave of specifically anti-Catholic media expression. 
profile and volatile nature of this issue on the American political landscape, and because this issue surfaces in every election cycle rather than sporadically, the Church is, by definition, thrust into the very heart of American legal debate. It is the debate over human life that keeps the Church most visibly involved in the political arena-and thus in the legal realm as well. ${ }^{60}$

In addition, the American bishops have issued pastoral statements on other pressing and controversial legal and political issues which have garnered significant attention in their own rights. Unlike the papal encyclicals, written for the global community, the statements of the American bishops are more narrowly written to reflect conflicts and opportunities unique to this country. Two in particular generated much debate-and controversy-in their respective fields. First, Economic Justice for $A l l{ }^{61}$ explored the complex moral issues related to the economic system, and the particular problems to which the American capitalist system is particularly vulnerable. The other was The Challenge of Peace ${ }^{62}$ which explored the question of warfare, weapons, nuclear proliferation, and obstacles to peace. Both of these documents placed American Church leaders in the heart of divisive political debate. More recently, American Church leaders have spoken forcefully on two highprofile, politically charged issues: the morality of the war in Iraq and the nature and definition of marriage.

Documents and statements such as these have enhanced the range of issues on which the Catholic Church has spoken. They have also increased the visibility of the Church as a participant in a range of issues. These ambitious projects have helped raise the profile of Catholic social teaching - a very important advance for a field often called the Church's "best kept secret." Whether these have had a direct bearing on law is less clear.

${ }^{60}$ See Weigel, supra note 2 , at 57, evaluating the difficulty in describing the impact of the Church's advocacy on this issue:

On the one hand ... the Church and its allies have kept the abortion issue alive when virtually every other center of culture formation has declared the issue resolved, in favor of abortion on demand...; on the other hand, the laws in favor of a freestanding abortion license remain in force.

${ }^{61}$ ECONOMIC JUSTICE FOR AlL, supra note 6.

62 The Challenge of Peace, supra note 4. 


\section{B. Limitations on the Impact of Catholic Social Teaching on American Law}

In spite of all of these ways in which Catholic social teaching has affected American law and society ${ }^{63}$ reflection on the future reveals some significant obstacles to having Catholic social thought play its full prophetic role in the modern American legal system. Three in particular are worth examining as the future of Catholic social thought in American life is considered. These three are:

(1) the general ambivalence toward the use of religious arguments in American political discourse;

(2) the fact that Catholic social teaching is deliberately written in broad strokes that lay out basic principles, but contain very few specific policy recommendations; and, perhaps most importantly

(3) Catholic social teaching is internally consistent and cohesive but it is wildly inconsistent with the way in which legal issues are currently arrayed in American politics.

\section{Ambivalence toward Religious Influence in American Law}

The first obstacle to the full impact of Catholic social thought in American legal life is one already addressed at length and with great insight by others. ${ }^{64}$ That obstacle is the profound ambivalence of American society to the use of religious arguments in public life and legal discourse. Indeed, this ambivalence is reflected in the very basic origins of the American government. At the same time that freedom from an imposed religious state was enshrined in the American Constitution, it was clear that the Founders openly embraced free religious

\footnotetext{
${ }^{63}$ See Carlson, supra note 38, at 339 ("The Catholic Church has played a significant role in society by exerting a Christian influence on the political and social order.").

${ }^{64}$ For a fuller discussion of the compatibility of religious arguments to democratic life, see, e.g. Michael J. Perry, Why Political Reliance on Religiously Grounded Morality Is Not Illegitimate in a Liberal Democracy, 36 WAKE FoReST L. REv. 217 (2001). As Perry notes, "the proper role of religious faith in the public life of the nation is one of the most controversial issues in the United States today." Id. at 218. See also Reichley, supra note 43, at 23 (exploring the role played by religion in American political life) and James E. Wood, Jr., The Prophetic Role of Religion in Society, 30 J. CHURCH \& ST. 219 (1988) (exploring paradox of having both strong secular and religious traditions in American history).
} 
practice, religious values, belief in the divine, and confidence in the existence of objective truths. ${ }^{65}$

This ambivalence continues today. ${ }^{66}$ The same society that fondly recalls the participation of religious groups in the civil rights and antiwar movements ${ }^{67}$ reacts with more reserve when contemplating the participation of religious groups in consideration of family or pro-life

\footnotetext{
${ }^{65}$ See, e.g., WE Hold These TruThs, supra note 42, at ix:

To our Fathers, the political and social life of man did not rest upon such tentative empirical hypotheses as the positivist might cast up. . [T] hey thought the life of man in society under government is founded on truths, on a certain body of objective truth, universal in its import, accessible to the reason of man, definable, defensible ... [T] he American Proposition rests on the more traditional conviction that there are truths; that they can be known; that they must be held; for if they are not held, assented to, consented to, worked into the texture of institutions, there can be no hope of founding a true City in which men may dwell in dignity, peace, unity, justice, well-being, freedom.
}

See also id. at 28 (arguing that the Declaration of Independence articulates "a truth that lies beyond politics; it imparts to politics a fundamental human meaning. I mean the sovereignty of God over nations as well as over individual men"); id. at 30 ("[T]he American political community was organized in an era when the tradition of natural law and natural rights was still vigorous."); Id. at 37 ("The philosophy of the Bill of Rights was also tributary to the tradition of natural law, to the idea that man has certain original responsibilities precisely as man, antecedent to his status as citizen... . [T]hey are not granted by government and they cannot be surrendered to government."); and Reichley, supra note 42 , at 23 ("The founders of the Republic drew on religious values and rhetoric in forming the new nation.").

${ }^{66}$ See Araujo, supra note 10, at 751. ("In contemporary American society, there persists a conflict or tension between those who publicly rely on their religious views and persons who believe in a 'strict separation' between church and state."); Scott C. Idleman, The Role of Religious Values in Judicial Decision Making, 68 IND. L. J. 433, 434 (1993) ["[R]eligion is frequently perceived as an inappropriate source of values in the policy-making or law-making process, including adjudication.") and Id. at 442 ("[R]eligion and religious values . . . are generally viewed as illegitimate sources from which to draw in the judicial decision-making process.").

${ }^{67}$ See Kent Greenawalt, Religion and American Political Judgments, 36 WAKE FoREST L. REv. 401 (2001) ("During the civil rights movement, church leaders helped to arouse the conscience of the country and religious individuals put their bodies on the line. Religious groups played a major role in opposition to the Vietnam War, and they have also led the fight against a liberal abortion law.") and Id. at 403 ("Those possessing [religious] insight should draw the appropriate conclusions and support political candidates and parties who reach the same conclusions. Many political liberals respond that this view improperly mixes religion and politics, but most liberals did not object when liberal religious leaders struggled for civil rights and publicly opposed the Vietnam War."); Henry J. Hyde, Keeping God in the Closet: Some Thoughts on the Exorcisms of Religious Values from Public Life, 1 Notre Dame J. L. Eтthics \& Pub. Pol'y 33, 37 (1984) [hereinafter God in the Closet] ("[T]he clergy were revered when they marched at Selma, joined the anti-war sit-ins and helped boycott lettuce; they are reviled when they speak against abortion."). 
issues. ${ }^{68}$ The same country whose currency proclaims "in God we trust" and whose Congress opens its sessions with prayer, is a country whose press sharply criticizes Catholic clergy for preaching on moral issues with legal implications. ${ }^{69}$ The same American population that is described by all statistics as being deeply religious ${ }^{70}$ is also one that is more comfortable with keeping religious beliefs private. ${ }^{71}$

Many scholars have debated the constitutionality of mixing religious beliefs with secular policy-making, and many philosophers have re-

${ }^{68}$ See Idleman, supra note 66, at 452:

[A] double standard appears to exist regarding the perception of religious participation in public life. ... [R]eligious participation in public life is apparently acceptable, even encouraged, on certain issues or when religion supports certain viewpoints-for example, when religious groups oppose nuclear proliferation or favor more social welfare programs - but it is forbidden on certain other issues or when religion supports certain other view points-for example, when religious groups oppose legalized abortion or euthanasia. As an illustration, one need only compare the praise given to religious groups or leaders for participating in the civil rights movements of the 1960's to the criticism and often harsh treatment given to religious groups and leaders for participating in the anti-abortion movement of the 1980's and 1990's.

69 See God in the Closet, supra note 67, at 40-41 ("[M]any of the same voices who hailed the American Bishops as 'prophetic' when they tacitly endorsed the nuclear freeze now find the Bishops 'scary' when the issues turns to abortion. This is hypocrisy.").

${ }^{\circ}$ See, e.g., Henry Hyde, Keeping the Promise of America in Catholics In THE PUBLIC Square 63 (Thomas Patrick Melady, ed. 1995) [hereinafter The Publ.rc Square] (noting the "undeniably religious character of our people"); BYRNES, supra note 41, at 5 (noting that the United States "is quite simply one of the most religious nations in the world"); and Greenawalt, supra note 67, at 406 ("[M]ore than ninety percent of our citizens identify themselves as religious."); Russell Kirk, Church Establishments and American Catholics, in When Conscience and Politics MeET, supra note 39, at 13, 20 ("Of the American people, about half are in communion with some church, or at least attend services with some regularity; while of the other half of the population, few are consciously hostile toward religion. If anywhere in the world Christian belief might be expected to inform public policy, it is in this country.").

${ }^{71}$ See, e.g., WE HoLd THESE TRUTHs, supra note 42, at 21 (observing that secularists in the United States have "traditionally had no quarrel with religion as a 'purely private matter,' as a sort of essence or idea or ambient aura that may help to warm the hidden heart of solitary man"); Idleman, supra note 66, at 450 ("Public life goes on without religion, although large numbers of Americans remain religiously faithful in private."); Dulles, supra note 10, at 277 ("In contemporary American culture there is a widespread assumption that religion is something private . . . and that it ought not to affect the way one acts in the public square."); and Id. at 284 ("Some Americans seem to feel that religion is so divisive a topic that it ought not to show itself on the public square. People have a right to be religious, they assert, so long as they keep their piety to themselves and do not urge their beliefs on others."). 
flected on the tension between private morality and public life. This ambivalence has, in turn, reduced the ability of Catholic social teaching-or, indeed, the social teaching of any denomination-to be a full participant in the raging social and legal debates of our day. Unfortunately, this exclusion of religious values from the public square greatly impoverishes American legal discourse. ${ }^{72} \mathrm{~A}$ democratic society flourishes best when ideas are presented, freely debated on their merits, and honestly voted on by those who have legislative authority to pass law. ${ }^{73}$

As a realistic matter, on many matters of critical importance today, it would be difficult for a religious legislator or, for that matter, for a

${ }^{72}$ See Perry, supra note 64, at 219, quoting Sen. Joseph Liberman who remarked:

It would truly be a sad thing if the religious and moral convictions upon which the American experiment was founded could now somehow be considered a danger to free society, such that those who would bring these convictions to bear upon [the] nation's public life would be denied a voice in debating and resolving issues of public policy.

See also Idleman, supra note 66, at 465 (lauding the values of providing "the opportunity for all citizens of all philosophical persuasions to participate in the law-making process, to have their views considered by lawmakers, and, if ultimately successful, to have their values reflected in the laws under which they must live"); $i d$. at 465 ("[E]xclusion of religion from the law-making process not only generates its own form of intolerance and denies religious citizens the opportunity to meaningfully shape public policy, it also sends the message to these citizens that their beliefs ... do not merit serious consideration."); David Hollenbach, S.J., Contexts of the Political Role of Religion: Civil Society and Culture, 30 SAN Diego L. REv. 877, 895-96 (1993) ("For a society to try to exclude religious narratives and symbols from public life simply because they are identified with religion would be to impoverish itself intellectually and culturally. This would deprive society of one of its most important resources for a more publicly shared cultural self-understanding."); Marci A. Hamilton, Religion in the Public Square: Free?, 42 WM. \& MARY L. REv. 823, 864 (2001) ("Churches are the most powerful human structure to challenge the assumptive power of the state, and should not be barred from speaking out frankly at these crucial moments in American politics not only for the sake of their members, but equally for the sake of nonmembers who have the right to know who is wielding the levers of power."); and John A. Coleman, Public Religion and Religion in Public, 36 WAKE FOREST L. Rev. 279, 293-298 (2001) (exploring contributions religious perspectives can bring to public life); LIVING THE GosPEL OF LIFE, supra note 3 , at 8 ("[D]emocracy is not served by silence . . Real pluralism depends on people of conviction struggling vigorously to advance their beliefs by every ethical and legal means at their disposal.").

${ }^{73}$ See, e.g., Hyde, supra note 70, at 62-70, 63 ("[D]espite the continuing hysteria in the elite culture and the prestige press, most Americans have come to understand that ... the systematic stripping of religion and religiously-based moral values from American public life-is profoundly undemocratic."); Greenawalt, supra note 67, at 406-407 (discussing "inclusive" view of religion's role in politics, centered on the view that "[a] full airing of all those views will enrich everyone's understanding"); and FAITHFUL CITIZENSHIP, supra note 9, at 4 ("Our nation is enriched and our tradition of pluralism enhanced when religious groups contribute to the debate over the policies that guide the nation."). 
religious voter, to make an honest assessment of solutions without consulting his or her religious values for guidance. ${ }^{74}$ For example, one who supports increased funding for impoverished children's health care may support that argument with economic evidence that funds saved in preventative care result in reduced costs on curative care. One may support that argument with medical evidence that good healthcare in a child's early years is essential for good health as an adult. One may even support that argument with an undefined romantic sentimentality in favor of young children. All of these arguments are readily welcomed and accepted in the public square and can be asserted boldly by a legislator presenting a legal initiative for such increased spending.

But, if that same legislator were to present the same initiative but justify it based on the principles of Catholic teaching that urge a special preferential option for the poor and vulnerable, he or she would risk being viewed with suspicion or accused of injecting mere personal morality into a matter of public policy. ${ }^{75}$ This results in a system in which religious views are not observed with mere neutrality but are viewed as less legitimate than other points of view. As long as this attitude persists, it will be difficult for Catholic social teaching to be fully valued in the marketplace of ideas.

\footnotetext{
${ }^{74}$ See Greenawalt, supra note 67, at 409 ("Most people would be hard put to try to carry out a program of excluding their deepest religious convictions from their political judgments."); Idleman, supra note 66 , at 435 ("[T]he broader one's definition of 'religious,' or the more liberal one's conception of religiousness, the more significant the notion of excluding religious values from judicial decision making becomes."); Randy Lee, The Immutability of Faith and the Necessity of Action, 66 FoRDHAM L. REv. 1455, 1456 (1998) ("For the lawyer ... who believes that religion is a relationship that penetrates her life, 'bleaching out' one's religion cannot be an option."); Stephen L. Carter, The Religiously Devout Judge, 64 Notre DAme L. Rev. 932, 934 (1989) ("[N]ot many people believe any longer that judges are capable of putting to one side all of their preconceptions when they set down to deliberate."); and Id. at 940 ("Religious faith is not something that can be shrugged off like an unattractive article of clothing.").

${ }^{75}$ This dichotomy is explored more fully in Carter, supra note 74, at 937:

In a nation that prides itself on cherishing religious freedom, it is something of a puzzle that a Communist or a Republican may try to have his world view reflected in the nation's law, but a religionist cannot; that one whose basic tool for understanding the world is empiricism may seek to have her discoveries taught in the schools, but one whose basic tool is Scripture cannot; that one whose conscience moves him to doubt the validity of the social science curriculum may move to have it changed, but one whose religious convictions moves her to doubt the validity of the natural science curriculum may not.
}

See also id. at 942 ("Many citizens enter into public debate on the basis of assumptions that they are unwilling to have challenged. Sometimes they win, sometimes they lose, but only if they base their assumptions on a religious understanding is their point of view entirely excluded from public dialog."). 
Legislators-Catholic or not--who see wisdom or truth in Catholic social teaching are faced with three equally unattractive options. They may disregard all that they learn from this teaching and reach decisions based on any and all influences except this religious one. However, it may simply be impossible to isolate that which one has come to believe through religious faith from that which one has come to believe through other influences. ${ }^{76}$ Thus, this is an untenable option. In the alternative, these legislators may take what they have learned from Catholic social thought and reach their decision influenced by it, but refrain from articulating religious belief as a rationale. This, too, is undesirable because it is, quite simply, dishonest and not the free and open discourse that should be welcomed in the public square. Finally, a legislator may honestly and openly disclose the influence of religious belief on decision-making. Unfortunately, however, the ambivalence toward religion's role will often devalue these arguments-either generally on all issues or, perhaps more unfairly, selectively as to some issues.

For Catholic social teaching to have a true and meaningful impact on American law and policy, this ambivalence must be overcome by a willingness to let ideas be put forth openly and honestly, without undue disadvantage to religious perspectives. In a pluralistic society, it is possible and, indeed, likely, that many will not find religious arguments to be persuasive ${ }^{77}$ That, however, is far more desirable than finding them absent from meaningful public debate-an approach that currently impoverishes the debate on fundamental moral questions. ${ }^{78}$

\section{The Broad Scope of Catholic Social Teaching}

A second aspect of Catholic social teaching that is one of its greatest strengths is also, ironically, one of the things that can undermine its

\footnotetext{
${ }^{76}$ See, e.g., Robert P. Casey, Reconciling Faith with American Life, in ThE PuBLIC SQUARE, supra note 70, at 72 ("[T]he obligation of a public official is to do what he thinks is right, to follow his own conscience, whether that conscience is formed by religious faith, experience, the natural law, common sense, or all of the above, as is often the case.").

${ }^{77}$ See Perry, supra note 64, at 230 ("Because of the role that religiously grounded moral beliefs inevitably play in the political process, ... it is important that such beliefs, no less than secular moral beliefs, be presented in public political argument so they can be tested there.").

${ }^{78}$ For a now classic, and in-depth analysis of the hostility of the American political and legal systems to religious perspectives, see generally StePHen L. CARTER, THe CULTURE OF DISBELIEF (1993).
} 
ability to have a broad impact on American law. Catholic social teaching, for the most part, sets out broad principles and moral values to guide the development of law, but it leaves to lay expertise the challenge of translating those broad values into specific law and political initiatives. ${ }^{79}$ There are some issues on which the Church's social teaching sets forth specific policy and programmatic recommendations. These, however, are few and far between. This is based on the view that "it does not belong to the Church, insofar as she is a religious and hierarchical community, to offer concrete solutions in the social, economic, and political spheres for justice in the world. Her mission involves defending and promoting the dignity and fundamental rights of the human person." 80

So, for example, the Church preaches the principle of subsidiarity, consistently teaching that problems should be resolved at the lowest level capable of effectively doing so. ${ }^{81}$ Yet, Catholic social teaching does not enumerate with specificity which issues are to be resolved at which level. Instead, it is left to lay policy-makers to wisely and honestly assess the proper place to resolve difficult legal and policy questions. ${ }^{82}$

${ }^{79}$ See John M. Garvey, The Pope's Submarine, 30 San Diego L. Rev. 849, 858-59 (1993) ("The Church's bishops are not by training or occupation its best informed members on questions of politics, science, social science, or even theology. The laity are expected to make practical, prophetic, and scholarly contributions.").

${ }^{80}$ JUSTICE IN THE WORLD, supra note 19, at 294.

${ }^{81}$ See, e.g., QUADRAGESIMO ANNo, supra note 14, II 79, at 60 ("[I]t is an injustice and at the same time a grave evil and a disturbance of right order to transfer to the larger and higher collectivity functions which can be performed and provided for by lesser and subordinate bodies."); MATER ET MAGISTRA, supra note 12, II 117, at 103 ("[T]he principle of subsidiarity . . . is to be strictly observed."); Id. II 152, at 109 ("[T] should favor and help private enterprise in accordance with the principle of subsidiarity, in order to allow private citizens themselves to accomplish as much as is feasible."); GAUDIUM ET SPES, supra note 15, II 75, at 217 ("[C]itizens, both as individuals and in association should be on guard against granting government too much authority and inappropriately seeking from it excessive conveniences and advantages); OCTOGESIMA ADVENIENS, supra note 15, II 46, at 282 (reiterating that politics should not "deprive individuals and intermediary bodies of the field of activity and responsibility which are proper to them"); and CenTESimus ANNus, supra note 13, II 48, at 476 (warning that "a community of a higher order should not interfere in the internal life of a community of a lower order, depriving the latter of its functions, but rather should support it in case of need"). For further discussion of the implications of subsidiarity, see generally Robert K. Vischer, Subsidiarity as a Principle of Governance: Beyond Devolution, 35 IND. L. REv. 103 (2001) (exploring modern practical implications of subsidiarity doctrine). See also Carmella, supra note 15, at 267-269 (discussing complex policy implications of subsidiarity doctrine).

${ }^{82}$ See, e.g., Introduction, supra note 12, at 6 ("[S]ocial, political, and economic problems are the special concern of the laity. They are uniquely qualified to describe what 
Likewise, in one sentence, Pope John Paul II said both that "workers should be assured the right to strike" 83 and that "a strike remains ... an extreme means." ${ }^{84}$ Yet, lay decision-makers are charged with deciding what factors to weigh in determining if a strike is abusive or "extreme." Similarly, Catholic social teaching sets forth broad teachings on such diverse issues as property rights, tax equity, environmental stewardship, health care, and immigration. Catholic leaders have testified before Congress in debates concerning these issues and have developed detailed statements on them. However, the Church's social teaching is not to be seen as a "think tank" from which emerge detailed policy proposals and programs. ${ }^{85}$ Instead, "[h]er contribution to the political order is precisely her vision of the dignity of the person revealed in all its fullness in the mystery of the Incarnate Word." ${ }^{86}$

Indeed, because Catholic social teaching is global in perspective and not created specifically for the United States, it cannot be overly concerned with parochial policy-making. ${ }^{87}$ As Pope Paul VI observed in Octogesima Adveniens:

[I]t is difficult for us to utter a unified message and to put forward a solution which has universal validity. Such is not our ambition, nor is it our mission. It is up to the Christian communities to analyze with objectivity the situation which is proper to their own country, to shed on it the light of the Gospel's unalterable words and to draw principles of reflection, norms of judgment and directives for action from the social teaching of the Church. . . . It is up to these Christian communities, with the help of the Holy Spirit, in communion with the bishops who hold responsibility and

in fact is going on and to evaluate what should be done."); and GAUDIUM ET SPES, supra note 15, II 43, at 192 ("Secular duties and activities belong properly although not exclusively to laymen. ... [A]cting as citizens of the world . . . they will observe the laws proper to each discipline, and labor to equip themselves with a genuine expertise in their fields.").

${ }^{83}$ LABOREM EXERCENS, supra note 45, II 20, at 381.

${ }^{84} \mathrm{Id}$. He went on to warn that the right to strike "must not be abused. It must not be abused especially for 'political' purposes." Id.

${ }^{85}$ See, e.g., Araujo, supra note 10, at 765 ("While the history of the Catholic Church's social teachings consistently promotes the social responsibility essential to community life, it does not define in a systematic fashion how an individual American's responsibility toward others is to be implemented.") and Dulles, supra note 11, at 286 ("Church teaching does not give detailed answers . . . but it lays down some important principles that should not be disregarded.").

${ }^{86}$ Centesimus Annus, supra note 13, II 47, at 475.

${ }^{87}$ In Octogesima Adveniens, Pope Paul VI commented on both the global and local nature of the issues facing the Church's attention, noting that while there are "problems ... particular to each part of the world . . . but at the same time they are common to all mankind." OCTOGEsima AdVENIENS, supra note 15, If 2, at 265. 
in dialogue with other Christian brethren and all men of good will, to discern the options and commitments which are called for in order to bring about the social, political, and economic changes seen in many cases to be urgently needed. ${ }^{88}$

This respectful attitude toward the vocation of politician and lawmaker and the desire to defer to it should, and in many ways, does, enhance the ability of Catholic teaching to have an impact on law and legislation. By offering its expertise in moral and ethical questions as a complement to rather than as a substitute for lay wisdom in legal affairs, the Church creates the possibility for legal results reached as the product of contributions from both of these traditions.

Unfortunately, however, this also means that the Catholic social tradition is not capable of being reduced to quick sound-bites or easy summary. Instead, it is nuanced and subtle in its approach. As a result, it can be difficult to easily translate these social principles to legal reality. ${ }^{89}$ This places on law-makers the responsibility to carefully study Catholic social teaching and understand its principles before being able to apply it easily or facilely to the problems they address. Indeed, as Gaudium et Spes itself noted:

[E]nlightened by Christian wisdom and giving close attention to the teaching authority of the Church, let the layman take on his own distinctive role.

Often enough, the Christian view of things will itself suggest some specific solution in certain circumstances. Yet it happens rather frequently, and legitimately so, that with equal sincerity some of the faithful will disagree with others ... [S]olutions proposed by one side or another may easily be confused with the Gospel message. Hence it is necessary for people to remember that no one is allowed in the aforementioned situations to appropriate the Church's authority for his opinion. They should always try to enlighten one another through honest discussion, preserving mutual charity and caring above all for the common good..$^{90}$

\footnotetext{
${ }^{88} I d$. II 4 , at 266.

${ }^{89}$ See Carmella, supra note 14 , at 271 :
}

Though the church's social teachings quite boldly proclaim many rights and duties and offer sophisticated social critique and reconstruction, they give no blueprint to answer these questions relating to the precise specification of the state's political-legal function. The silence is intentional, to respect national differences and give flexibility for problem solving.

${ }^{90}$ Gaudium ET Spes, supra note $15, \mathscr{T}$, 43, at 193. A similar sentiment was expressed by Pope Paul VI in Octogesima Adveniens when he commented, "[O]ne must recognize a legitimate variety of possible options. The same Christian faith can lead to different commitments." Octogesima AdVEnIENS, supra note 15, II 50, at 284. See also Centesimus ANNUS, supra note 13, II 43, at 471 ("The church has no models to present; models that are real and truly effective can only arise within the framework of different historical situations, through the efforts of all those who responsibly confront concrete problems 
However, in a fast-paced political world where decisions are often made quickly, it is more difficult to transform this more philosophical and sociological moral framework into concrete action. This can, in turn, make Catholic teaching on many issues difficult to translate into particular law and legislation-hence reducing its impact.

\section{Inconsistency of Catholic Social Teaching with Modern American Political Life}

The third aspect of Catholic social teaching that makes it more difficult to translate into American law is that teaching's uneasy relationship to the current landscape of American politics. This is, perhaps, its greatest challenge. As mentioned earlier, the Church's social teaching advocates independence from alliances with political parties and systems. ${ }^{91}$ This remarkable freedom can and does leave the Church at liberty to preach social teachings that are logically consistent according to its moral precepts. As summarized recently by the bishops of the United States, "[W]e believe every candidate, policy and political platform should be measured by how they touch the human person; whether they enhance or diminish human life, dignity, and human rights; and how they advance the common good." ${ }^{92}$ Yet, this framework leads the Catholic Church to advocate positions largely inconsistent according to the current array of American political alignments. ${ }^{93}$ For example, even

in all their social, economic, political and cultural aspects, as these interact with one another.") and Id. II 47, at 475 ("The church respects the legitimate authority of the democratic order and is not entitled to express preferences for this or that institutional or constitutional solution.").

${ }^{91}$ See discussion in notes 35-38, supra. See also Ireland, supra note 43, at 36 ("There is in America no Catholic political party, nor should there be. As a matter of course, were a special issue raised in which rights of Catholics were menaced, the conscience of Catholics were compelled to defend those rights on the ground of American fair play itself. That-and nothing more.").

${ }^{92}$ FarTHFul CitTZenshiP, supra note 9 , at 4.

${ }^{93}$ See BYRNES, supra note 41, at 114 ("Catholic bishops had staked out a new political position for themselves by developing an agenda that sharply diverged from the platforms of both political parties."); Hollenbach, supra note 72, at 882 ("[T] he Roman Catholic tradition has been suspicious both of social theories extolling the primacy of the state and of theories granting primacy to the market. At the same time, this tradition has rejected individualistic understandings of freedom. In fact, its rejection of an individualistic understanding of the self is the source of its suspicion of both liberal contract theories of politics and laissez faire models of economic life."); Paul Perl \& Jamie S. McClintock, The Catholic "Consistent Life Ethic" and Attitudes Toward Capital Punishment and Welfare Reform, 62 Sociology of Religion, Sept. 22, 2001, at 275 ("Because it combines a 'conservative' position on abortion with 'liberal' positions on many other policy areas, the [Catholic] ethic lies almost completely outside the realm 
the most cursory look at the two major political parties reveals, of course, that neither party is both opposed to abortion and opposed to the death penalty. Neither party fully embraces with equal vigor both the Catholic teaching on the traditional family ${ }^{94}$ and on the preferential option for the poor..$^{95}$

In many ways, this reality is the greatest strength of Catholic social teaching. By remaining unbeholden to either party, the Church is able to challenge both to provide a fuller manifestation of a just society. ${ }^{96} \mathrm{As}$ the Catholic Bishops Conference observed, "[w]e must challenge all parties and every candidate to defend human life and dignity, to pursue greater justice and peace, to uphold family life, and to advance the common good." 97 As an outsider to traditional partisan politics, the Church can remain a critical commentator, and need not worry about altering its message to win votes or political victory. ${ }^{98}$ Instead, it retains the freedom to speak its views on a wide range of issues and to let

of mainstream political culture and is rejected by most elites of both the right and the left.") and $I d$. ("[A]side from opposition to euthanasia, the positions with which the bishops have attempted to link abortion opposition are understood as 'liberal' in the context of broader American political culture.").

${ }^{94}$ See CEnTesimus AnNus, supra note 13 , II 39, at 468 (declaring that, in defining a family, "we mean the family founded on marriage, in which the mutual gift of self by husband and wife creates an environment in which children can be born and develop their potentialities, become aware of their dignity and prepare to face their unique and individual destiny").

${ }_{95}$ The preferential option for the poor has been announced in numerous social encyclicals. See, e.g., Rerum Novarum, supra note 14, II 29, at 28 ("[W] hen there is a question of protecting the rights of individuals, the poor and helpless have a claim to special consideration.") and SolLICITUDo REI SocLALIS, supra note 14, II 39, at 422 ("By virtue of her own evangelical duty, the Church feels called to take her stand beside the poor.").

${ }^{96}$ Indeed, in the long term, this may make Catholic voters more influential since "the Catholic vote is critical to both parties." See Powell, supra note 42, at 8 . In the short term, however, "the cultural and ethnic unity of American Catholics, deliverable as solid blocks of voters, the ultimate political argument in a democracy has massively declined." J. Bottum, The Moral Coherence of the Catholic Politician, CRIsIs, July/ August 2003, at 25.

${ }^{97}$ Faithrul Citizenship, supra note 9 , at 3.

${ }^{98}$ See Wood, supra note 64, at 224 (arguing that keeping religion and politics separate "makes possible a genuinely prophetic role of religion by freeing it of institutional alliances with the state that would modify or mute its prophetic voice") and $i d$. at 225 ("The Church that is relatively free of institutional alliances and entanglements with the state is one that is most favored to be able to carry out the prophetic role of religion in society through its free and authentic witness."). 
the consequences fall where they may. ${ }^{99}$ This, of course, is very different from the process followed by any political party engaging in platform drafting. There, principles and practicality can clash and result in a platform that reflects a mix of both genuine principles and compromises struck in the interest of electability.

This counter-cultural aspect of Catholic teaching-a framework internally consistent but politically inconsistent-is something which should, and often does, enhance its credibility. However, this can also, at least in the short term, reduce that teaching's impact on American law. ${ }^{100}$

Because the teachings have something in them to favor-and disfavor-views from nearly every political persuasion, Catholic social teaching has often been invoked selectively by those of every perspective to support their views. ${ }^{101}$ Politics are replete with examples of those who will tout Catholic social teaching on disarmament, but distance themselves from Catholic teaching on euthanasia, ${ }^{102}$ or those who will recite with enthusiasm the Church's respect for private property ${ }^{103}$ while downplaying its admonitions that private property bears a social mortgage that mandates respect for the universal destination of

${ }^{99}$ See, e.g., BYRNES, supra note 41, at 4 ("The Second Vatican Council envisioned the church as challenger and critic of modern culture."); GAUDIUM ET SPES, supra note 15, I 76 , at 219 (asserting that "it is always and everywhere legitimate for her to preach the faith with true freedom, to teach her social doctrine, and to discharge her duty among men without hindrance. She also has the right to pass moral judgments, even on matters touching the political order."); and FAITHFUL CITIZENSHIP, supra note 9, at 6 ("The Catholic approach to faithful citizenship begins with moral principles, not party platforms.").

${ }^{100}$ See Perl \& McClintock, supra note 93, at 275:

American Catholic Bishops have advocated a combination of issue positions that is unique within American political culture. The "consistent life ethic" combines opposition to abortion with liberal stances on other issues conceptualized as life-affirming. Based on evidence that very few people hold this combination of attitudes, previous researchers have concluded that the Bishops' advocacy has had little or no success.

${ }^{101}$ See, e.g., Casey, supra note 76, at 72 ("[W]e see in the national liberal and conservative politics of our country a temptation to ignore the serious demands of conscience. ... It seems to me that both ends of the political spectrum tend to fall prey to different sets of temptations.").

102 The Church's teaching on euthanasia is developed most fully in Evangelium VITAE, supra note 23, III 63-65, at 104-08. There, Pope John Paul II declared, "I confirm that euthanasia is a grave violation of the law of God, since it is the deliberate and morally unacceptable killing of a human person." Id. SI 65, at 107-08.

${ }^{103}$ See Rerum Novarum, supra note 14, II 7, at 16 ("[T] say that God has given the earth to the use and enjoyment of the universal human race is not to deny that there can be private property."); Id. II 7, at 17 ("[P]rivate ownership is according to nature's 
goods. ${ }^{104}$ This uneasy relationship can interfere with the full integration of the total message of Catholic teaching into American political discourse. Consequently, a body of doctrine that was developed to challenge all to a more just view of life can also lull into complacency those who accept part of it but resist the challenge and the discomfort inherent in realizing that neither party neatly captures the full range of Catholic social teaching consistently or completely. ${ }^{105}$

law."); Id. II 8, at 17 (calling private ownership "preeminently in conformity with human nature, and . . . conducive in the most unmistakable manner to the peace and tranquility of human life"); id. II 35, at 32 ("[P]rivate ownership must be held sacred and inviolate."); QUADRAGESIMO ANNO, supra note 14, II 45, at 52 ("[T] he right to own private property has been given to man ... by the Creator himself, not only in order that individuals may be able to provide for their own needs and those of their families, but also that by means of it, the goods which the Creator has destined for the human race may truly serve this purpose."); MATER ET MAGISTRA, supra note 12, at 86 ("Private property ... is a natural right possessed by all, which the State may by no means suppress."); Id. II 109 , at 101 ("[T] he right of private property . . is permanently valid."); Id. II 121, at 104 ("[T] he right of private ownership is clearly evident in the Gospels."); GAUDIUM ET SPES, supra note 15, II 71, at 214 ("Private ownership or some other kind of dominion over material goods provides everyone with a wholly necessary area of independence and should be regarded as an extension of human freedom."); LABOREM EXERCENS, supra note 45, II 14, at 371 (reasserting "the right to private property, even when it is a question of the means of production."); and CEnTESIMUS ANNUS, supra note 13, II 30 , at 461 (noting that the right to private property "is fundamental for the autonomy and development of the person").

${ }^{104}$ See, e.g., RERUM NovARUM, supra note 14, 9I 7, at 17 ("[T] among private owners, ceases not thereby to minister to the needs of all."); MATER ET MAGISTRA, supra note 12, II 19, at 87 ("[T] property."); Id. II 119, at 103 ("[I]n the right of private property there is rooted a social responsibility."); GAUDIUM ET SPES, supra note 15, II 71, at 214 ("By its very nature, private property has a communal purpose of earthly goods. If this social quality is overlooked, property often becomes an occasion of greed and of serious disturbances."); Populorum Progressio, supra note 35, \[ 23, at 245 ("[P] rivate property does not constitute for itself an absolute and unconditional right. No one is justified in keeping for his exclusive use what he does not need when others lack necessities."); LABOREM ExERCENS, supra note 45, II 14, at 371 ("The right to private property is subordinated to the right to common use, to the fact that goods are meant for everyone."); Id. II 14, at 372 ("[T] he position of 'rigid' capitalism continues to remain unacceptable, namely the position that defends the exclusive right to private ownership of the means of production as an untouchable 'dogma' of economic life."); Sollicitudo Rei Socialis, supra note 14, II 42, at 426 ("[T] he goods of this world are originally meant for all. The right to private property is valid and necessary, but it does not nullify the value of this principle."); Id. (describing the "social mortgage" which accompanies private property); CenTEsimus ANNUS, supra note 13, II 30, at 461 ("[T] he possession of material goods is not an absolute right."); and $I d$. (declaring that private ownership of goods "is subordinated to their original common destination as created goods, as well as to the will of Jesus Christ. ...").

${ }^{105}$ Indeed, the Catholic Bishops themselves noted this when they observed, "Sometimes it seems few candidates and no party fully reflect our values. But now is not a 
Two temptations can thus arise to undermine the influence of Catholic social teaching on American political discourse-the discourse from which flows so much of American law. For some, the temptation may be to selectively reduce Catholic social teaching to merely those words or phrases that support one's legal perspective while ignoring those that do not. ${ }^{106}$ This denies the depth and breath of that teaching. For others, the temptation may be to ignore Catholic social teaching entirely to avoid being accused of the inconsistency or hypocrisy that can come with selective use of the Church's teaching. This excludes the Catholic perspective from public debate.

In light of this political reality and the way in which legal issues have become arrayed politically, the relationship between the Church's teachings on the dignity of human life and the rest of its social teaching warrants particular attention. This is a source of great political tension and, in reality, it is likely to be impossible for the full impact of Catholic social teaching to be appreciated in its full range unless the raging questions on human life and dignity are resolved in American law in a way consistent with Catholic social teaching.

There is a richness and a fullness in Catholic social teaching that spans a broad range of issues. However, the Church has consistently placed the sanctity of human life at the forefront of her teachings. A declaration to this effect may be found in nearly all documents articulating the Church's social vision. ${ }^{107}$ It is the innate dignity of the person

time to retreat." FAITHFUL CitizENSHIP, supra note 9, at 3; Id. at 4 ("Our moral framework does not easily fit the categories of right or left, Democrat or Republican. Our responsibility is to measure every party and platform by how its agenda touches human life and dignity.").

${ }^{106}$ Bottum, supra note 96 , at 20, 22. ("[P]oliticians can find a Catholic theologian to provide grounds for allowing almost any political position.").

${ }^{107}$ See, e.g., MATER ET MAGISTRA, supra note 12, II 194, at 116 ("[A]ll must regard the life of man as sacred, since, from its inception, it requires the action of God the Creator."); GAUDIUM ET SPES, supra note 15, II 51, at 199-200 ("God, the Lord of life, has conferred on men the surpassing ministry of safeguarding life-a ministry which must be fulfilled in a manner which is worthy of man. Therefore, from the moment of its conception, life must be guarded with the greatest care, while abortion and infanticide are unspeakable crimes."); JUSTICE IN THE WORLD, supra note 19, at 289 (calling life "man's highest good"); SHaRING Catholic Social Teaching, supra note 10, at 1-2 ("Catholic social teaching is based on and inseparable from our understanding of human life and dignity. ... Every person, from the moment of conception to natural death, has inherent dignity and a right to life consistent with that dignity."); Id. at 4 ("Our belief in the sanctity of human life is the foundation of all the principles of our social teaching."); Dulles, supra note 10, at 282-83 ("The first principle, the dignity of human 
which is the foundation of the rest of the Church's social teaching, and "a consistent ethic of life should be the moral framework from which to address all issues in the political arena." ${ }^{108}$ Hence, while arguing on the one hand that all social issues constitute a seamless web, ${ }^{109}$ the Church also asserts that, without respecting the right to life, all the other social goods of the world rest on a shaky foundation. ${ }^{110}$

persons, rules out all laws that violate personal rights, beginning with the most fundamental, the right to life.... According to Catholic social teaching, the God-given right to life extends to the unborn. Hence, there can be no such thing as a right to abort or a right not to be born."); Evangelium VITAE, supra note 23, II 71, at 117 ("[C]ivil law must ensure that all members of society enjoy respect for certain fundamental rights which innately belong to the person. First and fundamental among these is the inviolable right to life of every innocent human being."); Id. (stating that civil law "can never presume to legitimize as a right of individuals ... an offence against other persons caused by the disregard of so fundamental a right as the right to life"); FAITHFUL CiTIZENSHIP, supra note 9, at 5 ("Because of our faith in Jesus Christ, we start with the dignity of the human person."); and Id. at 6 ("The conviction that human life is sacred and that each person has inherent dignity that must be respected in society, lies at the heart of Catholic social teaching."); LIVING THE GoSPEL OF LIFE, supra note 3, at 7 ("[F]or citizens and elected officials alike, the basic principle is simple: we must begin with a commitment never to intentionally kill, or collude the killing, of any innocent human life ... In other words, the choice of certain ways of action is always and radically incompatible with the love of God and the dignity of the human persons created in His image.").

${ }^{108}$ FatThFul Citizenship, supra note 9 , at 6.

109 See Perl \& McClintoch, supra note 93, passim, for further discussion on the "seamless web" theory and the role of Joseph Cardinal Bernadin in articulating it.

${ }^{110}$ See MATER ET MAGISTRA, supra note 12, If 215, at 119 ("[W] hatever the progress in technology and economic life, there can be neither justice nor peace in the world so long as men fail to realize how great is their dignity, for they have been created by God."); EVANGELIUM VITAE, supra note 23, at 5 (declaring "the sacred value of human life from its very beginning until its end" and that "[u]pon the recognition of this right, every community and the political community itself are founded"); id. II 101, at 159-60:

It is impossible to further the common good without acknowledging and defending the right to life, upon which all the other inalienable rights of individuals are founded and from which they develop. A society lacks solid foundation when, on the one hand, it asserts values such as the human dignity of the person, justice and peace, but then, on the other hand, radically acts to the contrary by allowing or tolerating a variety of ways in which human life is devalued and violated.... Only respect for life can be the foundation and guarantee of the most precious and essential goods of society, such as democracy and peace.

See also Faithrul Citizenship, supra note 9, at 6 ("Calls to advance human rights are illusions if the right to life itself is subject to attack."); LIVING THE GOSPEL OF LIFE, supra note 3 , at 3 ("A]bortion and euthanasia have become preeminent threats to dignity because they directly attack life itself, the most fundamental human good and the condition for all others."); $I d$. at 8, arguing that while Catholic decision makers must advocate for human dignity across a wide range of issues: 
The political array in the United States often pits the right to life against other aspects of Catholic social teaching, and can place those who are influenced by Catholic social teaching in a quandary. ${ }^{111}$ Catholic social teaching is aimed toward the fullness of human dignity in all its aspects. If life itself, the minimal level of dignity is not respected, then reaching this fullness of dignity is, by definition, unattainable. Yet, once this minimum is achieved, it betrays Catholic teaching to stop there and fail to move beyond the minimum. Hence, the challenge for Catholic social teaching-and the challenge for its influence on American law-is profound.

In order to move American law toward its vision of the fullness of human dignity, it must steadfastly and vocally advocate those legal and social initiatives that defend life. This is a difficult mandate in a society hostile to its perspective. This challenge may often involve a harsh conflict with those who, in good faith and with enthusiasm, steadfastly support other aspects of Catholic social teaching. ${ }^{112}$ At the same time, while it pushes for the threshold, foundational protection of life, the

Being "right" in such [other] matters can never excuse a wrong choice regarding direct attacks on innocent human life. Indeed, the failure to protect and defend life in its most vulnerable stages renders suspect any claim to the "rightness" of positions in other matters affecting the poorest and least powerful of the human community. If we understand the human person as ... the living house of God ... then those latter issues fall logically into place as the crossbeams and walls of that house. All direct attacks on innocent human life, such as abortion and euthanasia, strike at the house's foundation. These directly and immediately violate the human person's most fundamental right-the right to life. Neglect of these issues is the equivalent of building our house on sand.

111 This also raises a significant pastoral challenge for Catholics religious leaders. See James Hitchcock, Catholics in the Public Square, in When Conscience and Politics MEET, supra note 39:

The Church has of course remained firmly opposed to abortion, and has invested a great deal of moral capital and energy in the struggle against it. But the theory conventionally called the "seamless garment" ... has effectively undercut that commitment at numerous points.... [I]t has left Catholics with no meaningful guidance in determining their votes, since they usually face a choice between candidates both of whom seem to address some of the "life issues," as the Church bureaucracy defines them, but not others.

More importantly, the "seamless garment" formula, and the entire thrust of Catholic social teaching as defined at the national level, makes the abortion issue seem anomalous... . In countless ways American Catholics have been encouraged by their national leaders to view the world essentially through the glasses of the left wing of the Democratic Party, a view in which abortion inevitably seems an oddity at best, and ultimately a terrible misjudgment.

${ }^{112}$ See LIVING THE GoSPEL OF LIFE, supra note 3, at 7 ("There is such a wide spectrum of issues involving the protection of human life and the promotion of human dignity. Good people frequently disagree on which problems to address, which policies to adopt..."). 
Church must also challenge those who support its teaching on this issue to acknowledge that the full dignity of humanity does not allow the complacency that can come with discounting significant aspects of the rest of Catholic social teaching. ${ }^{113}$

\section{Conclusion}

The Catholic church is the single largest religious denomination in the United States. ${ }^{114}$ Its social teaching has been centuries in the making, with roots that are philosophical and theological as well as inspirational, historical, and sociological. ${ }^{115}$ Yet, there have been some obstacles that have limited its ability to influence American law. As Catholic social teaching becomes more widely studied and discussed, its potential to influence American law can only increase. Many years ago, the earliest of the social encyclicals were addresses only to Catholic bishops. They were then addressed only to Catholics. Now, however, Catholic social encyclicals are addressed to all of "good will." "As the

${ }^{113}$ See id. at 8 ("Opposition to abortion and euthanasia does not excuse indifference to those who suffer from poverty, violence, and injustice. Any politics of human life must work to resist the violence of war and the scandal of capital punishment. Any politics of human dignity must seriously address issues of racism, poverty, hunger, employment, education, housing, and health care. Therefore, Catholics should eagerly involve themselves as advocates in all these areas.").

${ }^{114}$ See Thomas Melady, Introduction, in The Public Square, supra note 70 (noting that "The Catholic community currently comprises around twenty-five percent of the American population.") and Garvey, supra note 79, at 849 ("Catholics are the largest denomination in the United States. . . . The Catholic church also asserts more authority over its members . . . than most American sects do."). For an international perspective, see Weigel, supra note 2, at 37 ("[T]he Catholic Church is the largest religious community on the planet, numbering some 1.1 billion adherents.").

${ }^{115}$ See God in the Closet, supra note 67, at 44. ("American Catholics are in a privileged position to make enormously useful contributions to the development of . . . public philosophy. We are the inheritors of a two thousand year old tradition of careful thought about the relationship between personal conscience and public policy.").

${ }^{116}$ Rerum Novarum, for example was addressed to "Our Venerable Brethren, All Patriarchs, Primates, Archbishops and Bishops of the Catholic World, In Grace and Communion with the Apostolic see." See RERum Novarum, supra note 14, at 14. Quadragesimo Anno was addressed to this same group plus "All the Faithful of the Catholic World." QuADRAGESIMo ANNo, supra note 14, at 42. Mater et Magistra was addressed to "Our Venerable Brothers, the Patriarchs, Primates, Archbishops, Bishops, and Other Local Ordinaries in Peace and Communion with the Holy See, and to All the Clergy and Faithful of the Catholic World." Mater ET MAGistra, supra note 12, at 84. Populorum Progressio, however, was a landmark in that it was addressed "To the Bishops, Priests, Religious, the Faithful, and to All Men of Good Will.", Populorum Progressio, supra note 35, at 240 (emphasis added). In Centesimus Annus, the audience included "All Men 
audience for these encyclicals has broadened, the Church has expressed optimism that its social message can have a broader, more universal impact. ${ }^{117}$ This optimism is justified when one reflects on the ways in which the Church's participation in American legal debate has grown over the past century. However, as we reflect on the future, it is important to address those challenges that face the United States as it tries to make its law more fully reflect the hopes and aspirations of Catholic social teaching.

In anticipation of the dawn of this new century, Pope John Paul II wrote, "we can already glimpse the third millennium of the Christian era, so filled with uncertainties but also with promises-uncertainties and promises which appeal to our imagination and creativity, and which reawaken our responsibility ... to show the way." ${ }^{118}$ The "responsibility ... to show the way" is a weighty one for those who strive to advance the ideals of Catholic social teaching and implement them in American law. However, Catholic social teaching also expresses great confidence in human "imagination and creativity" and the hope that, when directed toward law, there is a role for that teaching in the building of a more just world.

and Women of Good Will," Cen'resimus AnNus, supra note 13, at 439 (emphasis added), while Evangelium Vitae, more recently, was addressed most simply to "The Bishops, Priests, and Deacons, Men and Women Religious, Lay Faithful, and All People of Good Will." Evangelium Vitae, supra note 23 (emphasis added).

${ }^{117}$ See Araujo, supra note 10, at 778 ("The social teachings of the Church are not a parochial command; they are a universal inspiration to do more of the better for the individual and for society in the world."); Dulles, supra note 10, at 279 ("Unlike the Church's strictly doctrinal teaching, which is addressed specifically to believers, Catholic social teaching is directed to all persons of good will, including those of any or no religion. It presupposes only that its addressees are interested in building a just and peaceful society on earth."); and Weigel, supra note 2, at 36 (calling development of Catholic social teaching to be "of interest beyond the formal boundaries of the Catholic Church and engage the concerns of Protestants, Jews, Muslims, and all men and women of goodwill who are concerned about the future of democracy").

118 Centesimus AnNus, supra note 13 , II 3 , at 440. 